\title{
Tailoring the Binding Properties of Phosphazane Anion Receptors and Transporters
}

Alex J. Plajer, Jinbo Zhu, Patrick Proehm, Andrew D. Bond, Ulrich F. Keyser and Dominic S. Wright.

\section{Contents}

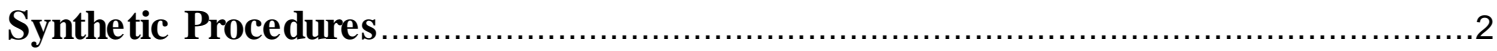

1 Synthesis of New Compounds

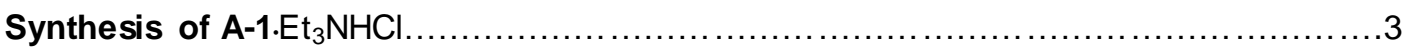

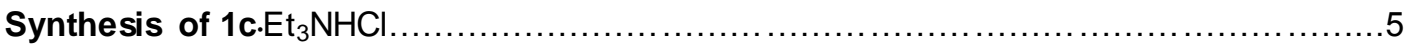

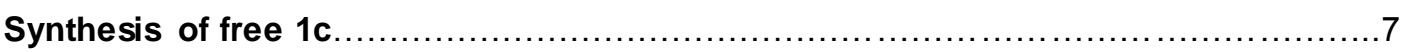

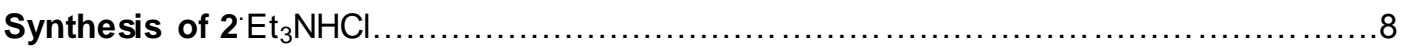

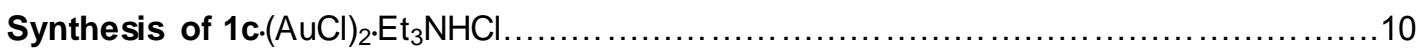

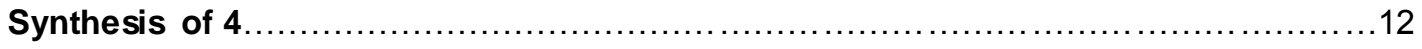

2. Binding Constants and NMR Titrations ................................14

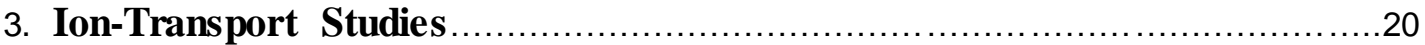

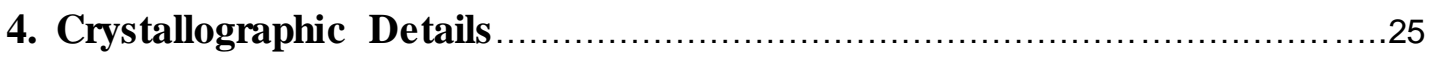

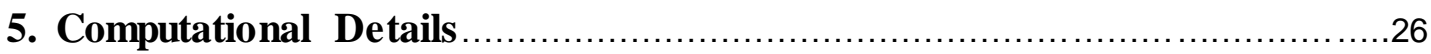




\section{Synthetic Procedures}

\section{General Experimental Methods}

All experiments involving phosphorus(III) containing species were carried out on a Schlenk-line under nitrogen atmosphere or with the aid of a $\mathrm{N}_{2}$-filled glove box (Saffron type $\alpha$ ). Toluene and THF were dried under nitrogen over sodium or sodium/benzophenone, respectively, whereas acetonitrile and $\mathrm{CH}_{2} \mathrm{Cl}_{2}$ was dried over calcium hydride. ${ }^{1} \mathrm{H},{ }^{13} \mathrm{C}\left\{{ }^{1} \mathrm{H}\right\},{ }^{31} \mathrm{P}\left\{{ }^{1} \mathrm{H}\right\}$ NMR spectra were recorded on a Bruker Avance 400 QNP or Bruker Avance $500 \mathrm{MHz}$ cryo spectrometer. All spectra were recorded with $\mathrm{SiMe}_{4}\left({ }^{1} \mathrm{H}\right), \mathrm{H}_{3} \mathrm{PO}_{4}\left({ }^{31} \mathrm{P}, 85 \%\right.$ in $\left.\mathrm{D}_{2} \mathrm{O}\right)$ and $\mathrm{C}_{6} \mathrm{H}_{5} \mathrm{~F}\left({ }^{19} \mathrm{~F}, 0.1 \mathrm{M}\right.$ in $\left.\mathrm{CDCl}_{3}\right)$ as external standards and referenced to the residual solvent signal. All reagents were purchased from commercial sources and used as received without further purification unless stated differently. $\left[P\left(\mu-N^{t} B u\right) C l\right]_{2},[P(\mu-$ $\left.\left.\mathrm{N}^{t} \mathrm{Bu}\right) \mathrm{NH}^{\mathrm{t}} \mathrm{Bu}\right]_{2},\left[\mathrm{P}\left(\mu-\mathrm{N}^{\mathrm{t}} \mathrm{Bu}\right) \mathrm{NH}_{2}\right]_{2},\left[\mathrm{E}=\mathrm{P}\left(\mu-\mathrm{N}^{\mathrm{t}} \mathrm{Bu}\right) \mathrm{NH}^{\mathrm{t}} \mathrm{Bu}\right]_{2}(\mathrm{E}=\mathrm{O}, \mathrm{S}, \mathrm{Se})$ were synthesized according to previously published procedures. ${ }^{1-6}$ Elemental analysis was obtained using a Perkin Elmer 240 Elemental Analyser. Low resolution electrospray ionisation (LR-ESI) mass spectrometry was undertaken on a Micromass Quattro LC mass spectrometer (cone voltage 10-30 eV; desolvation temp. $313 \mathrm{~K}$; ionization temp. $313 \mathrm{~K}$ ) infused from a Harvard syringe pump at a rate of $10 \mu \mathrm{L} \mathrm{min}{ }^{-1}$ 


\section{Synthesis of new compounds}

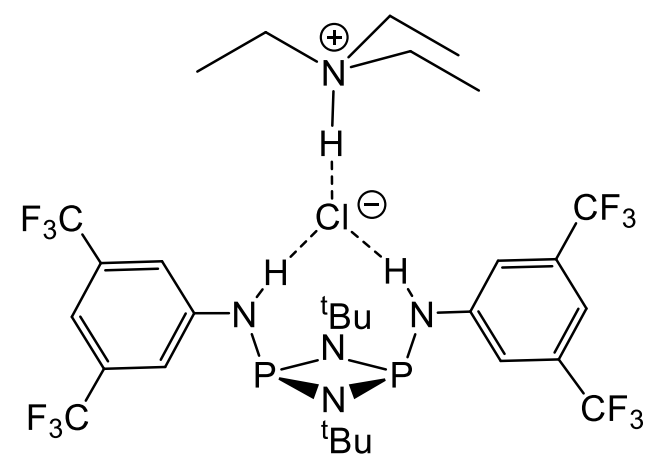

Synthesis of A-1.Et $t_{3} \mathrm{NHCl}$ : Inside a $\mathrm{N}_{2}$ filled glovebox a Schlenk tube was charged with $\left[\mathrm{P}\left(\mu-\mathrm{N}^{\mathrm{t}} \mathrm{Bu}\right) \mathrm{Cl}\right]_{2}$ (275mg, $1 \mathrm{mmol}$ ) and transferred to a Schlenk line. $20 \mathrm{ml}$ of THF and 3,5-Bis(trifluoromethyl)aniline (458mg, $2 \mathrm{mmol}$, 2 equivalents). The solution was cooled to $0{ }^{\circ} \mathrm{C}$ and $2 \mathrm{ml}$ of dry $\mathrm{NEt}_{3}$ were added dropwise. The resulting mixture was allowed to warm to room temperature and then stirred overnight at $40^{\circ} \mathrm{C}$. Afterwards the solvent was removed in vacuo and the resulting solid mixture was extracted with $40 \mathrm{ml}$ of hexane. The solvent was removed in vacuo space until the precipitation of a white solid was observed which was gently heated back into solution. Storage of the solution at -20 ${ }^{\circ} \mathrm{C}$ led to the formation of colourless crystal suitable for X-ray diffraction which were isolated by filtration and dried in vacuo to yield $\mathbf{A}-1 \mathrm{c}$. Et ${ }_{3} \mathrm{NHCl}$ as a colourless powder (240mg, $0.30 \mathrm{mmol}, 30 \%$ ).

${ }^{1} \mathrm{H}$ NMR $\left(25^{\circ} \mathrm{C}, \mathrm{CD}_{3} \mathrm{Cl}, 500.12 \mathrm{MHz}\right): \delta[\mathrm{ppm}]=11.85\left(\mathrm{~s}, 1 \mathrm{H}, \mathrm{HNEt}_{3}\right), 7.62(\mathrm{~s}, 4 \mathrm{H}, \mathrm{o}-\mathrm{Ar}), 7.26(\mathrm{~s}, 2 \mathrm{H}, \mathrm{m}-$ $\mathrm{Ar}), 7.13(\mathrm{~s}, 2 \mathrm{H}, \mathrm{HNAr}), 3.10\left(\mathrm{q},{ }^{3} \mathrm{~J}_{\mathrm{HH}}=7.2 \mathrm{~Hz}, 6 \mathrm{H}, \mathrm{HN}\left(\mathrm{CH}_{2} \mathrm{CH}_{3}\right)_{3}\right), 1.41\left(\mathrm{t},{ }^{3} \mathrm{~J}_{\mathrm{HH}}=7.2 \mathrm{~Hz}, 9 \mathrm{H}\right.$, $\left.\left.\mathrm{HN}\left(\mathrm{CH}_{2} \mathrm{CH}_{3}\right)_{3}\right)\right), 1.28\left(\mathrm{~s}, 18 \mathrm{H},{ }^{\mathrm{t}} \mathrm{Bu}\right)$.

${ }^{31} \mathrm{P}$ NMR $\left(25^{\circ} \mathrm{C}, \mathrm{CD}_{3} \mathrm{Cl}, 202.48 \mathrm{MHz}\right): \delta[\mathrm{ppm}]=108.19(\mathrm{~s})$.

Elemental analysis (\%) calcd. for A-1.Et ${ }_{3} \mathrm{NHCl}$ : calcd C 45.2\% H 5.3\% N 8.8\%, found C $45.1 \% \mathrm{H} \mathrm{5.3 \%} \mathrm{N}$ $8.7 \%$.

LRESI-MS (-ve ion): simul (Phosphazane $\cdot \mathrm{Cl}^{-}$) 695.11, found 695.05 


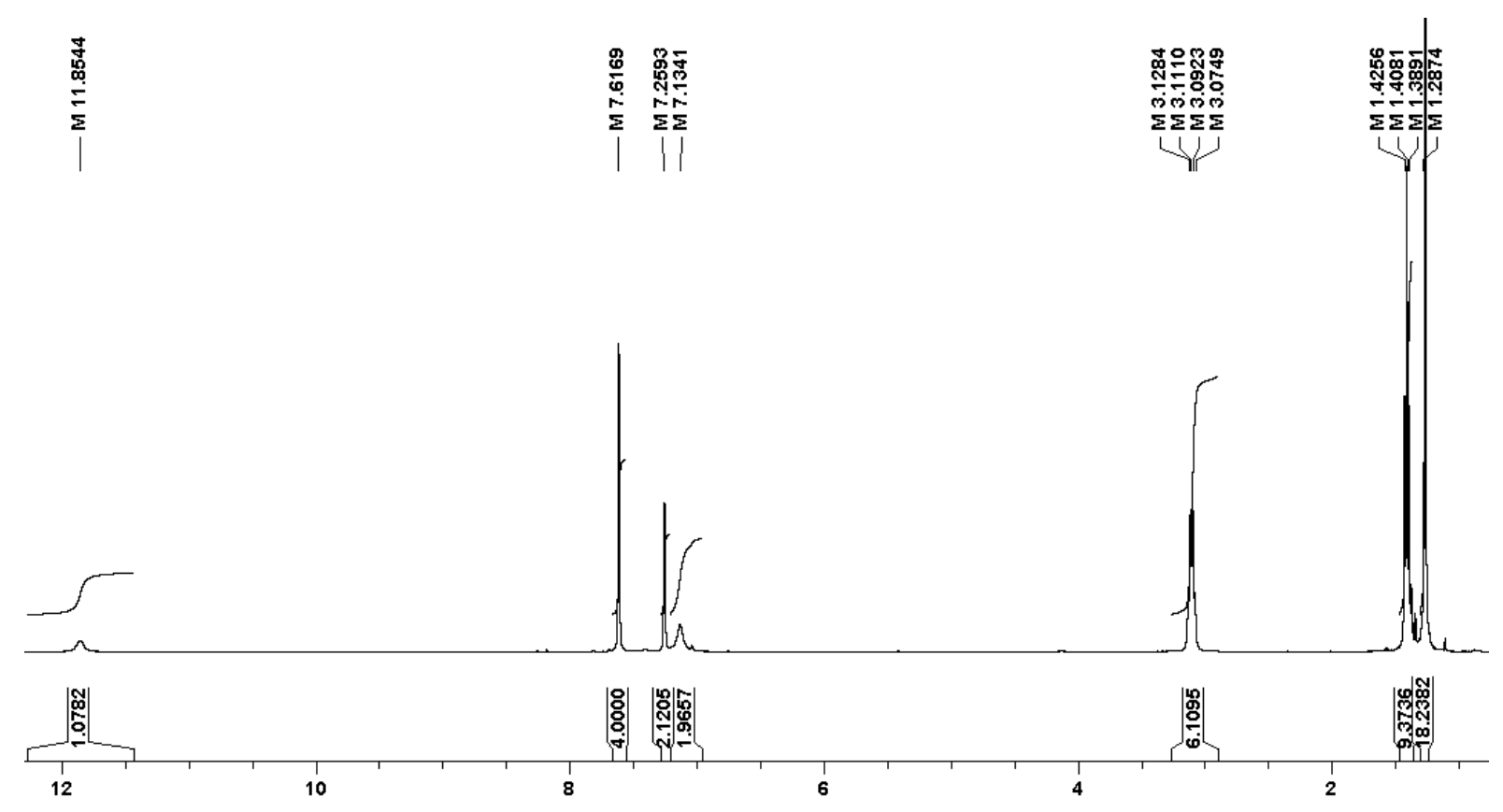

Figure S 1: ${ }^{1} \mathrm{H} N M R$ spectrum $\left(25^{\circ} \mathrm{C}, \mathrm{CD}_{3} \mathrm{Cl}, 500.12 \mathrm{MHz}\right)$ of $\mathrm{A}-1 . \mathrm{Et} \mathrm{t}_{3} \mathrm{NHCl}$.

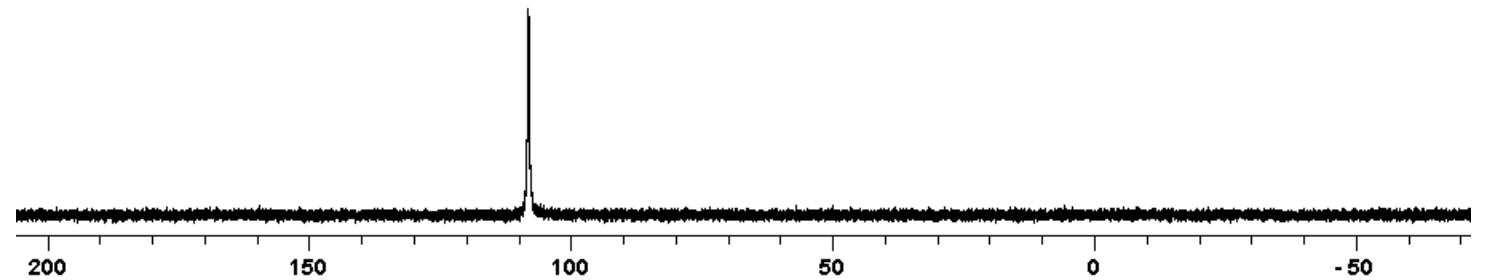

Figure S 2: ${ }^{31} \mathrm{P}$ NMR spectrum $\left(25^{\circ} \mathrm{C}, \mathrm{CD}_{3} \mathrm{Cl}, 202.48 \mathrm{MHz}\right)$ of $\boldsymbol{A}-\mathbf{1} \cdot \mathrm{Et}_{3} \mathrm{NHCl}$. 


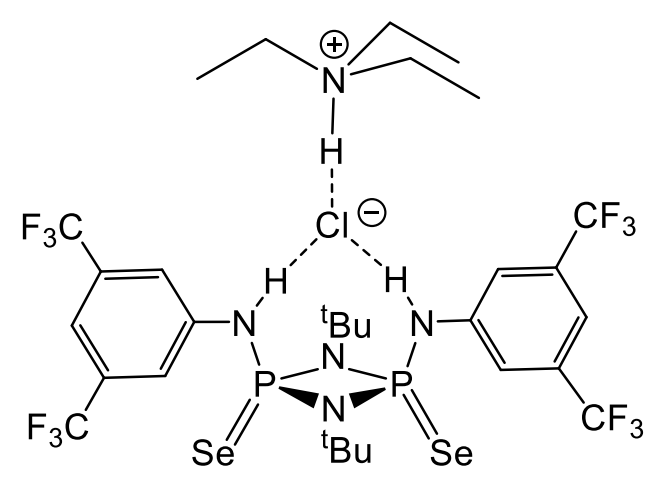

Synthesis of $1 \mathrm{c} \cdot \mathrm{Et}{ }_{3} \mathrm{NHCl}$ : Inside a $\mathrm{N}_{2}$ filled glovebox a Schlenk tube was charged with $\left[\mathrm{P}\left(\mu-\mathrm{N}^{\mathrm{t}} \mathrm{Bu}\right) \mathrm{Cl}\right]_{2}$ $(275 \mathrm{mg}, 1 \mathrm{mmol}$ ) and transferred to a Schlenk line. $20 \mathrm{ml}$ of THF and 3,5-Bis(trifluoromethyl)aniline (458mg, $2 \mathrm{mmol}$, 2 equivalents) were added. The solution was cooled to $0{ }^{\circ} \mathrm{C}$ and $2 \mathrm{ml}$ of dry $\mathrm{NEt}_{3}$ were added dropwise. The resulting mixture was allowed to warm to room temperature and then stirred overnight at $40^{\circ} \mathrm{C}$. Afterwards selenium (316mg, $4 \mathrm{mmol}, 4$ equivalents) was added and the mixture was stirred at room temperature. The reaction progress was monitored by in situ ${ }^{31} \mathrm{P} N M R$ spectroscopy. After completion of the reaction the solvent was removed in vacuo and resulting solid mixture was extracted with $20 \mathrm{ml}$ toluene. The solvent was removed in vacuo to yield $1 \mathrm{c}$. $\mathrm{Et}_{3} \mathrm{NHCl}$ as a

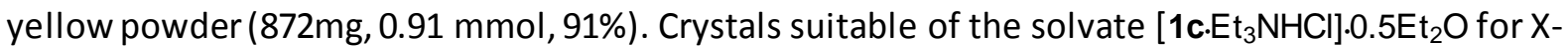
ray crystallography were obtained by layering an $\mathrm{Et}_{2} \mathrm{O}$ solution of $1 \mathrm{c} \cdot \mathrm{Et}_{3} \mathrm{NHCl}$ with pentane.

${ }^{1} \mathrm{H}$ NMR $\left(25^{\circ} \mathrm{C}, \mathrm{CD}_{3} \mathrm{Cl}, 500.12 \mathrm{MHz}\right): \delta[\mathrm{ppm}]=10.98\left(\mathrm{~s}, 1 \mathrm{H}, \mathrm{HNEt}_{3}\right), 8.80(\mathrm{~s}, 2 \mathrm{H}, \mathrm{HNAr}), 8.20(\mathrm{~s}, 4 \mathrm{H}, \mathrm{o}-$ $\left.\mathrm{Ar}), 7.52(\mathrm{~s}, 2 \mathrm{H}, m-\mathrm{Ar}), 3.13\left(\mathrm{q},{ }^{3} \mathrm{~J}_{\mathrm{HH}}=7.2 \mathrm{~Hz}, 6 \mathrm{H}, \mathrm{HN}\left(\mathrm{CH}_{2} \mathrm{CH}_{3}\right)_{3}\right),\right)^{2}, 1.62\left(\mathrm{~s}, 18 \mathrm{H},{ }^{\mathrm{t}} \mathrm{Bu}\right), 1.37\left(\mathrm{t},{ }^{3} \mathrm{~J}_{\mathrm{HH}}=\right.$ $7.2 \mathrm{~Hz}, 9 \mathrm{H}, \mathrm{HN}\left(\mathrm{CH}_{2} \mathrm{CH}_{3}\right)_{3}$.

${ }^{31} \mathrm{P}$ NMR $\left(25^{\circ} \mathrm{C}, \mathrm{CD}_{3} \mathrm{Cl}, 202.48 \mathrm{MHz}\right): \delta[\mathrm{ppm}]=31.51$ (s, with two satellite doublets arising from $\left.\left[\left({ }^{77} \mathrm{Se}=\right) \mathrm{HRN}-\mathrm{P}(\mu-\mathrm{N} \mathrm{tBu}) \mathrm{P}-\mathrm{NRH}(=\mathrm{Se})\right],{ }^{1} \mathrm{~J}_{\mathrm{PSe}}=908 \mathrm{~Hz},{ }^{2} \mathrm{~J}_{\mathrm{PP}}=20 \mathrm{~Hz}\right)$.

Elemental analysis (\%) calcd. for 1 c.Et ${ }_{3} \mathrm{NHCl}$ : calcd C $37.7 \% \mathrm{H} \mathrm{4.4 \%} \mathrm{N} \mathrm{7.3 \%} \mathrm{found} \mathrm{C} 37.8 \% \mathrm{H}$ 4.5\% N $7.4 \%$.

LRESI-MS (-ve ion): simul (Phosphazane $\cdot \mathrm{Cl}^{-}$) 854.95 found 854.90. 


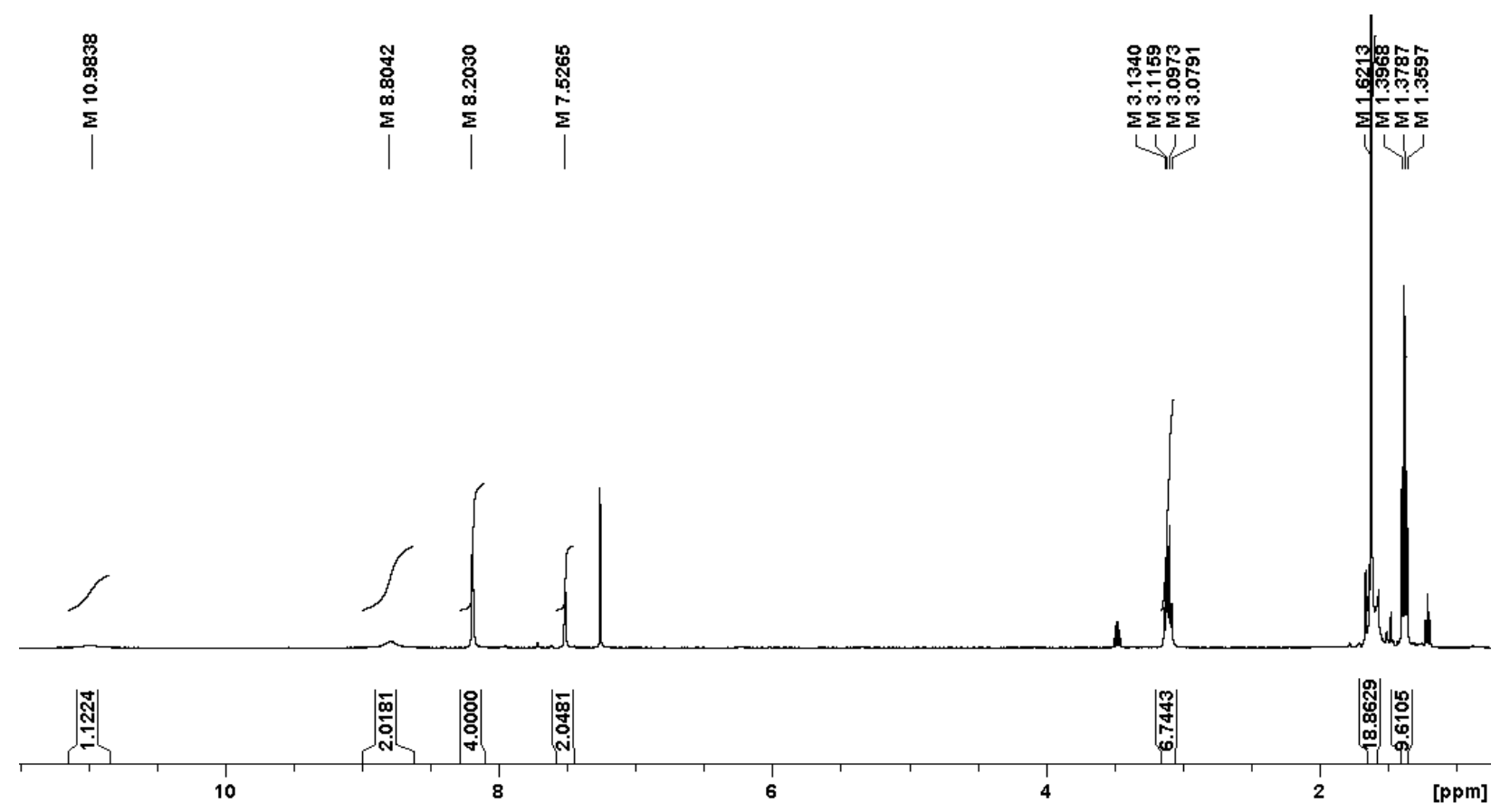

Figure S 3: ${ }^{1} \mathrm{H}$ NMR spectrum $\left(25^{\circ} \mathrm{C}, \mathrm{CD}_{3} \mathrm{Cl}, 500.12 \mathrm{MHz}\right)$ of $1 \mathrm{c} . \mathrm{Et} \mathrm{t}_{3} \mathrm{NHCl}$.

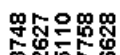

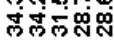

il

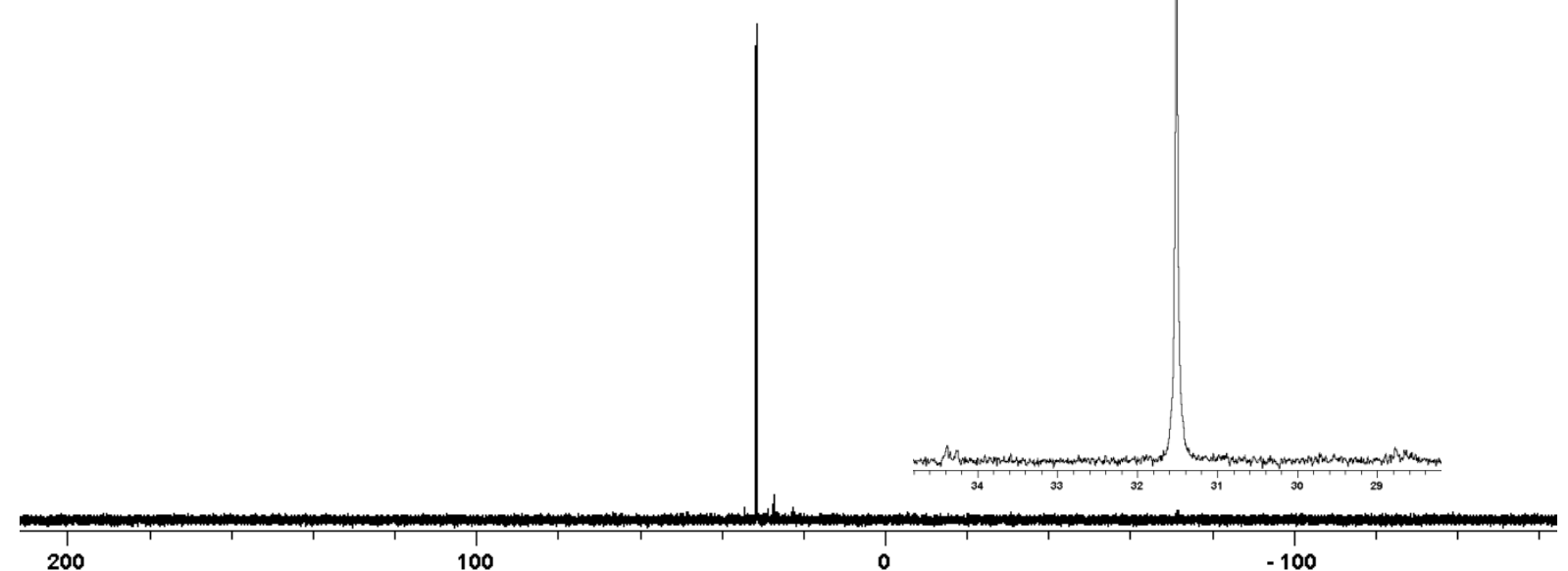

100

Figure S 4: ${ }^{31} \mathrm{P} N \mathrm{NR}$ spectrum $\left(25^{\circ} \mathrm{C}, \mathrm{CD}_{3} \mathrm{Cl}, 202.48 \mathrm{MHz}\right)$ of $1 \mathrm{c} . \mathrm{Et}_{3} \mathrm{NHCl}$.<smiles>CC(C)(C)P(=S)(Nc1cc(C(F)(F)F)cc(C(F)(F)F)c1)Nc1cc(C(F)(F)F)cc(C(F)(F)F)c1</smiles> 
Synthesis of free 1c: $1 \mathrm{c} \cdot \mathrm{Et}_{3} \mathrm{NHCl}\left(100 \mathrm{mg}, 0.1 \mathrm{mmol}\right.$ ) was dissolved in $20 \mathrm{ml} \mathrm{of} \mathrm{Et}_{2} \mathrm{O}$. The solution was washed three times with $10 \mathrm{ml}$ of water and afterwards dried with anhydrous $\mathrm{MgSO}_{4}$. The solvent was removed in vacuo to yield 1c as a yellow powder $(84 \mathrm{mg}, 85 \%)$.

${ }^{1} \mathrm{H}$ NMR $\left(25^{\circ} \mathrm{C}, \mathrm{CD}_{3} \mathrm{Cl}, 500.12 \mathrm{MHz}\right): \delta[\mathrm{ppm}]=7.71(\mathrm{~s}, 4 \mathrm{H}, o-\mathrm{Ar}), 7.68(\mathrm{~s}, 2 \mathrm{H}, m-\mathrm{Ar}), 5.78(\mathrm{~s}, 2 \mathrm{H}, \mathrm{NH})$, $1.65\left(\mathrm{~s}, 18 \mathrm{H},{ }^{\mathrm{t}} \mathrm{Bu}\right)$.

${ }^{31} \mathrm{P}$ NMR $\left(25^{\circ} \mathrm{C}, \mathrm{CD}_{3} \mathrm{Cl}, 202.48 \mathrm{MHz}\right): \delta[\mathrm{ppm}]=30.38$ (s, with two satellite doublets arising from $\left[\left({ }^{77} \mathrm{Se}=\right)\right.$ HRN-P( $\left.\left.\left.\mu-\mathrm{N} \mathrm{tBu}\right) \mathrm{P}-\mathrm{NRH}(=\mathrm{Se})\right],{ }^{1} \mathrm{~J}_{\mathrm{PSe}}=927 \mathrm{~Hz},{ }^{2} \mathrm{~J}_{\mathrm{PP}}=25 \mathrm{~Hz}\right)$.

Elemental analysis (\%) calcd. for 1c: calcd C 35.2\% H 3.2\% N 6.8\%, found C 35.1\% H 3.4\% N 6.8\%.

LRESI-MS (-ve ion): simul (1c· $\left.\mathrm{Cl}^{-}\right)$854.95, found 854.90.
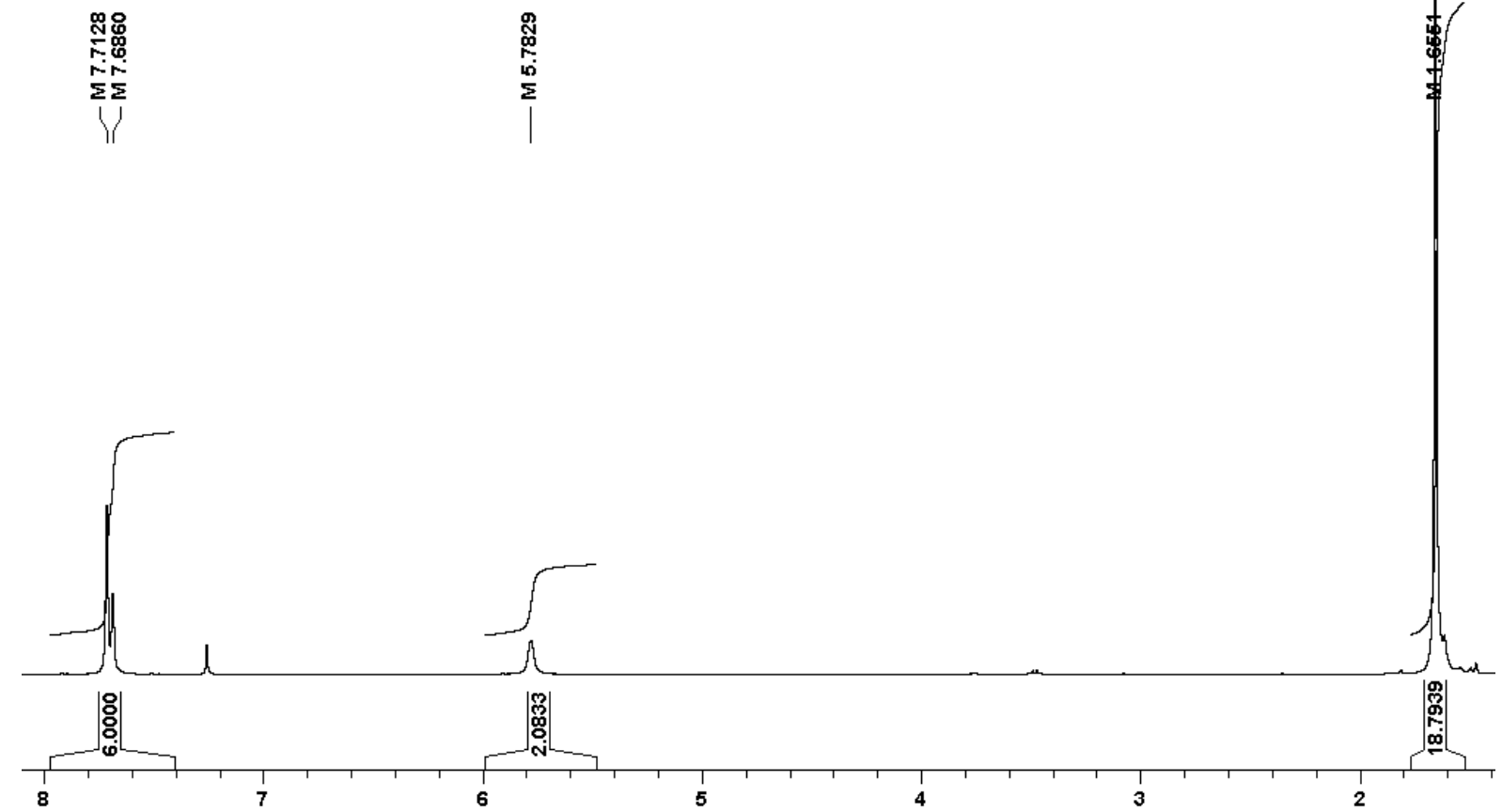

Figure S 5: ${ }^{1} \mathrm{H}$ NMR spectrum $\left(25^{\circ} \mathrm{C}, \mathrm{CD}_{3} \mathrm{Cl}, 500.12 \mathrm{MHz}\right)$ of $1 \mathrm{c}$ 


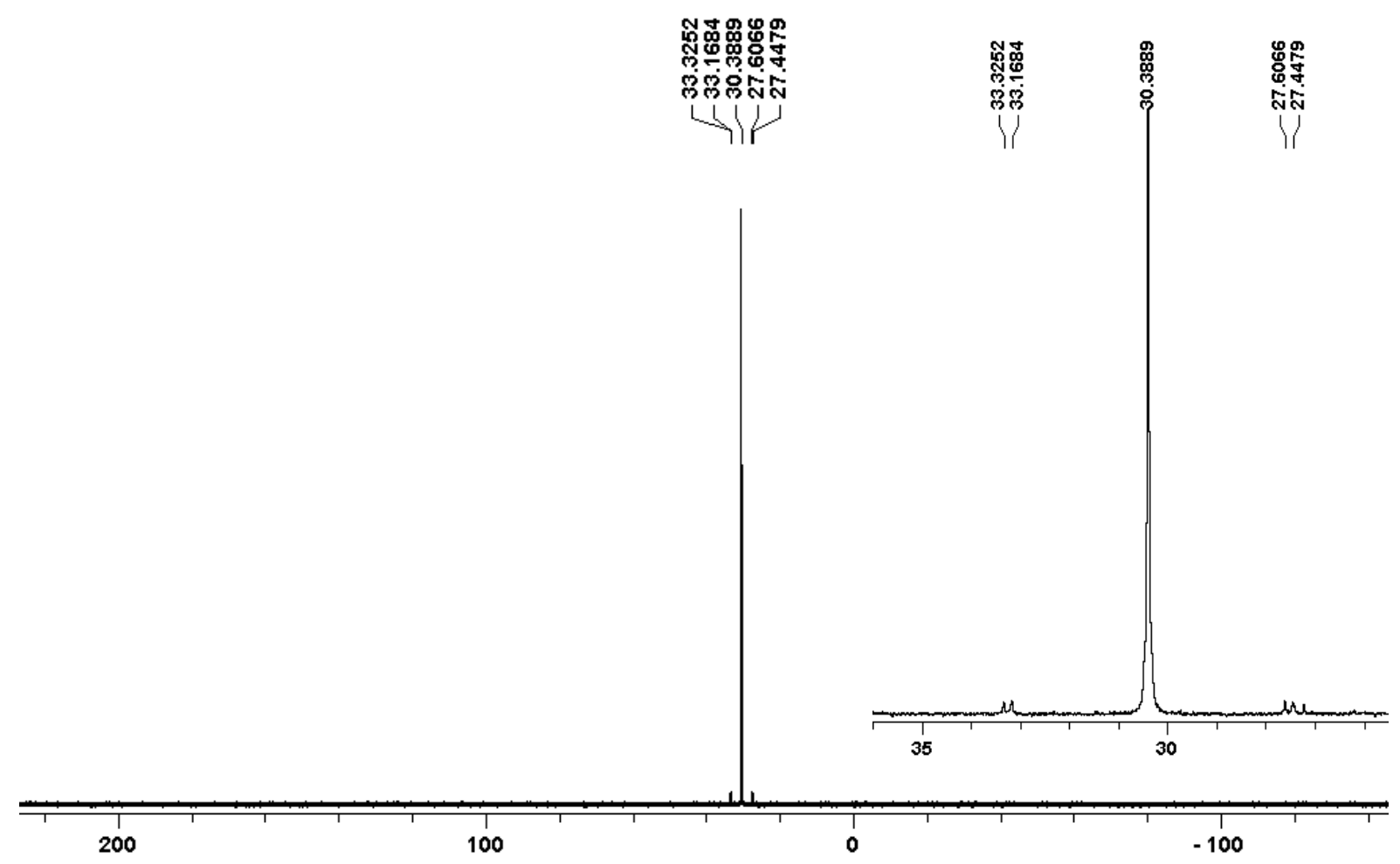

Figure S6: ${ }^{31} \mathrm{P} N \mathrm{NR}$ spectrum $\left(25^{\circ} \mathrm{C}, \mathrm{CD}_{3} \mathrm{Cl}, 202.48 \mathrm{MHz}\right)$ of $1 \mathrm{c}$

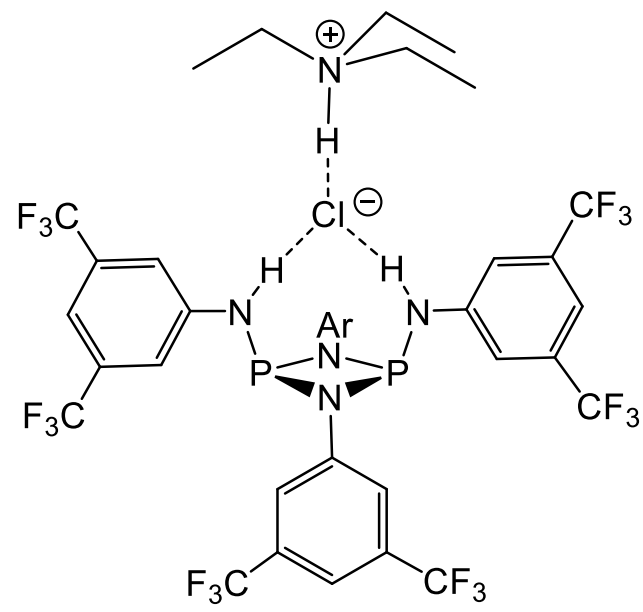

Synthesis of $2 \mathrm{Et}_{3} \mathrm{NHCl}$ : A Schlenk tube was charged with $\mathrm{PCl}_{3}(0.44 \mathrm{~g}, 3.21 \mathrm{mmol})$ and $25 \mathrm{ml}$ of toluene. The resulting solution was cooled to $-78^{\circ} \mathrm{C}$ and $25 \mathrm{ml}$ of $\mathrm{NEt}_{3}$ were added. To this $(3,5-$ bistrifluoromethyl)aniline $(1.47 \mathrm{~g}, 6.42 \mathrm{mmol})$ was added dropwise at $-78^{\circ} \mathrm{C}$ and mixture was slowly allowed to warm to room temperature overnight during which time a thick white suspension formed. All solvents were removed in vacuo and the resulting solid was extracted with $100 \mathrm{ml}$ of hexane. The filtrate was concentrated in vacuo until the precipitation of a white solid was observed which was dissolved into solution by gentle heating. Storage at $-14^{\circ} \mathrm{C}$ yielded a white crystalline solid which was recrystallized twice from hexane to yield $5 \mathrm{Et}_{3} \mathrm{NHCl}$ as colourless crystals suitable for single crystal $\mathrm{X}$ ray diffraction (112 $\mathrm{mg}, 0.1 \mathrm{mmol}, 6.3 \%)$. 
${ }^{1} \mathrm{H}$ NMR $\left(25^{\circ} \mathrm{C}, \mathrm{CD}_{3} \mathrm{Cl}, \mathbf{5 0 0 . 1 2} \mathrm{MHz}\right): \delta[\mathrm{ppm}]=11.10\left(\mathrm{~s}, 1 \mathrm{H}, \mathrm{HNEt}_{3}\right), 9.39(\mathrm{~s}, 2 \mathrm{H}, \mathrm{HNAr}), 7.86\left(\mathrm{~s}, 4 \mathrm{H}, \mathrm{o}^{-}\right.$ Ar), $\left.7.47(\mathrm{~s}, 2 \mathrm{H}, m-\mathrm{Ar}), 7.40(\mathrm{~s}, 2 \mathrm{H}, m-\mathrm{Ar}), 7.30(\mathrm{~s}, 4 \mathrm{H}, o-\mathrm{Ar}), 3.02\left(\mathrm{q},{ }^{3} \mathrm{~J}_{\mathrm{HH}}=7.2 \mathrm{~Hz}, 6 \mathrm{H}, \mathrm{HN}\left(\mathrm{CH}_{2} \mathrm{CH}_{3}\right)_{3}\right),\right)$ ), $1.31\left(\mathrm{t},{ }^{3} \mathrm{~J}_{\mathrm{HH}}=7.2 \mathrm{~Hz}, 9 \mathrm{H}, \mathrm{HN}\left(\mathrm{CH}_{2} \mathrm{CH}_{3}\right)_{3}\right.$.

${ }^{31} \mathrm{P}$ NMR $\left(25^{\circ} \mathrm{C}, \mathrm{CD}_{3} \mathrm{Cl}, 202.48 \mathrm{MHz}\right): \delta[\mathrm{ppm}]=113.47(\mathrm{~s})$.

Elemental analysis (\%) calcd. for $2 . \mathrm{Et}_{3} \mathrm{NHCl}$ : calcd C $41.1 \% \mathrm{H} 2.7 \% \mathrm{~N} 6.3 \%$ found C $41.5 \% \mathrm{H} 2.9 \% \mathrm{~N}$ $6.2 \%$.

LRESI-MS (-ve ion): simul (Phosphazane $\left.\cdot \mathrm{Cl}^{-}\right) 1007.00$ found 1006.90.
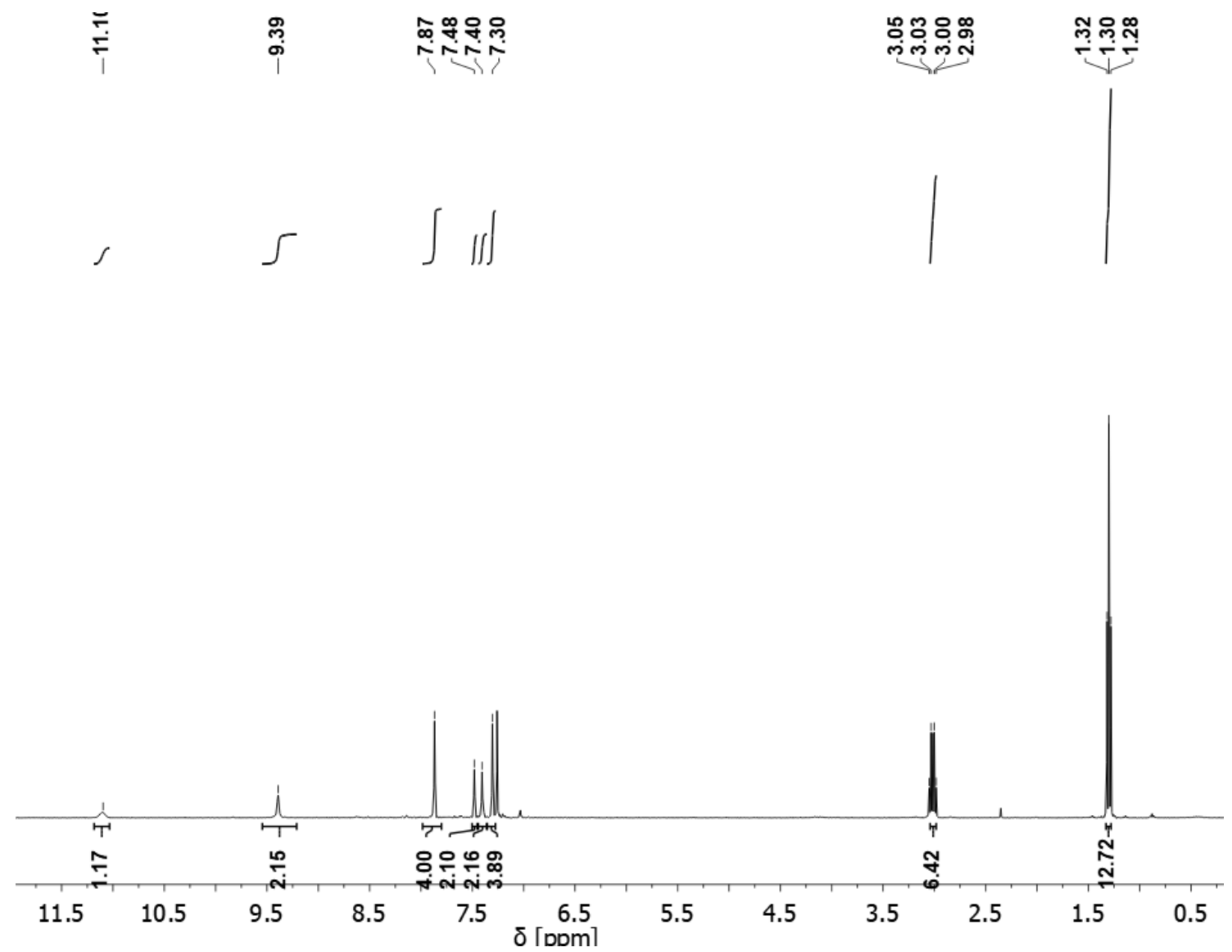

Figure $\mathrm{S} 7:{ }^{1} \mathrm{H}$ NMR spectrum $\left(25^{\circ} \mathrm{C}, \mathrm{CD}_{3} \mathrm{Cl}, 500.12 \mathrm{MHz}\right)$ of $2 \mathrm{Et}{ }_{3} \mathrm{NHCl}$. 


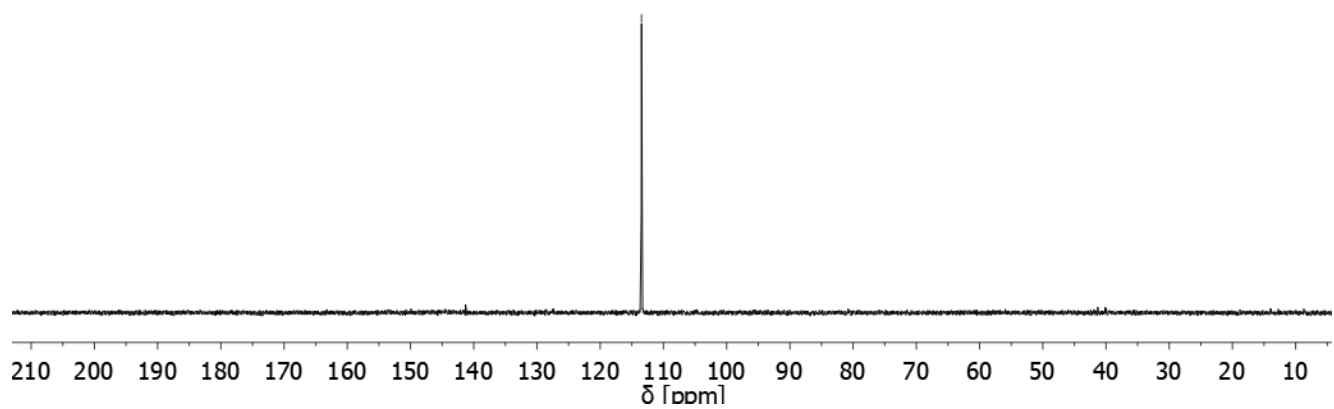

Figure S 8: ${ }^{31} \mathrm{P} N \mathrm{NR}$ spectrum $\left(25^{\circ} \mathrm{C}, \mathrm{CD}_{3} \mathrm{Cl}, 202.48 \mathrm{MHz}\right)$ of $2 \mathrm{Et}_{3} \mathrm{NHCl}$.

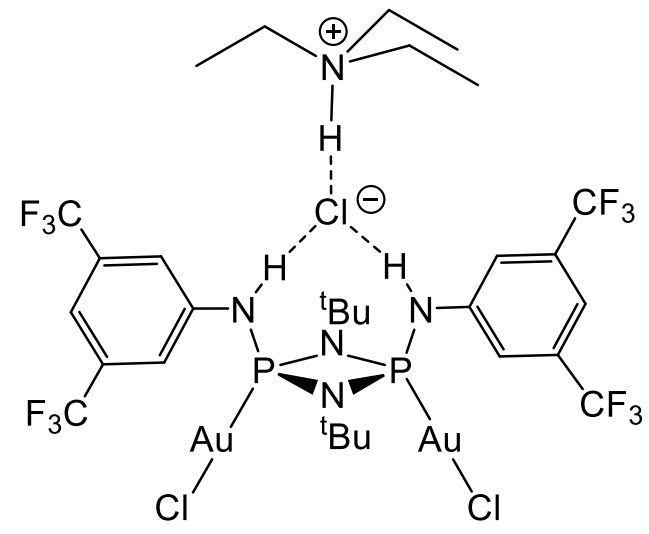

Synthesis of 1c. $(\mathrm{AuCl})_{2} \cdot \mathrm{Et}_{3} \mathrm{NHCl}$ : Inside a $\mathrm{N}_{2}$ filled glovebox a Schlenk tube was charged with A1c. $\mathrm{Et}_{3} \mathrm{NHCl}$ (100mg, $\left.0.13 \mathrm{mmol}\right)$ and $\left(\mathrm{Me}_{2} \mathrm{~S}\right) \mathrm{AuCl}(74 \mathrm{mg}, 0.26 \mathrm{mmol} 2 \mathrm{eq})$. The Schlenk tube was transferred to a Schlenk line and $2 \mathrm{ml}$ of $\mathrm{CH}_{2} \mathrm{Cl}_{2}$ were added. The resulting solution was stirred at 10 $\mathrm{min}$ at room temperature. Afterwards pentane was added dropwise until the formation then dissolution of a white precipitate was observed. The solution was stored at $4^{\circ} \mathrm{C}$ for 3 days which led to the formation of colourless crystals suitable for X-ray crystallography. The crystals were isolated by filtration and dried in vacuo to yield 1c. $(\mathrm{AuCl})_{2} \cdot \mathrm{Et}_{3} \mathrm{NHCl}$ as a colorless solid (109mg, 0.09mmol, 66\%).

${ }^{1} \mathrm{H}$ NMR (25 $\left.{ }^{\circ} \mathrm{C}, \mathrm{CD}_{3} \mathrm{Cl}, \mathbf{5 0 0 . 1 2} \mathrm{MHz}\right): \delta[\mathrm{ppm}]=10.11\left(\mathrm{~s}, 1 \mathrm{H}, \mathrm{HNEt}_{3}\right), 9.38$ (s, 2H, HNAr), 7.90 (s, 4H, oAr), $7.59(\mathrm{~s}, 2 \mathrm{H}, m-\mathrm{Ar}), 3.15\left(\mathrm{dq}, 6 \mathrm{H},{ }^{3} \mathrm{~J}_{\mathrm{H}}=2.7\right.$ and $\left.6.8 \mathrm{~Hz}, \mathrm{HN}\left(\mathrm{CH}_{2} \mathrm{CH}_{3}\right)_{3}\right), 1.59\left(\mathrm{~s}, 18 \mathrm{H},{ }^{\mathrm{t}} \mathrm{Bu}\right), 1.40(\mathrm{t}, 9 \mathrm{H}$, $\left.{ }^{3} \mathrm{~J}_{\mathrm{H}}=6.8 \mathrm{~Hz}, \mathrm{HN}\left(\mathrm{CH}_{2} \mathrm{CH}_{3}\right)_{3}\right)$.

${ }^{31} \mathrm{P}$ NMR $\left(25^{\circ} \mathrm{C}, \mathrm{CD}_{3} \mathrm{Cl}, 202.48 \mathrm{MHz}\right): \delta[\mathrm{ppm}]=81.97(\mathrm{~s})$.

Elemental analysis (\%) calcd. for 1c. $(\mathrm{AuCl})_{2}$. Et ${ }_{3} \mathrm{NHCl}$ : calcd C $28.5 \% \mathrm{H} \mathrm{3.3 \%} \mathrm{N} \mathrm{5.6 \% ,} \mathrm{found} \mathrm{C} 28.3 \% \mathrm{H}$ $3.4 \%$ N 5.5\%. 
LRESI-MS (-ve ion): simul ([1c. $\left.\left.\left(\mathrm{AuCl}_{2}\right)_{2} \cdot \mathrm{Et}_{3} \mathrm{NHCl}\right] \cdot \mathrm{Cl}^{-}\right) 1158.98$ found 1158.90.
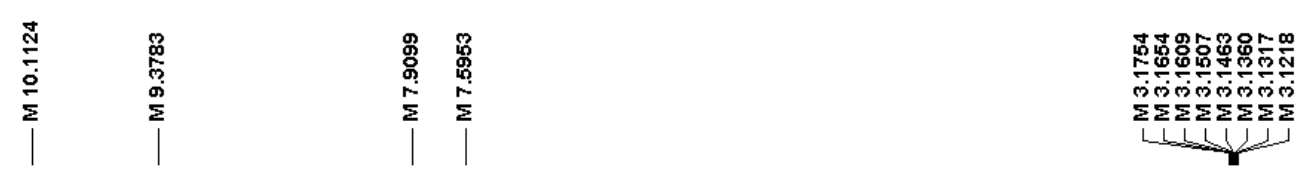

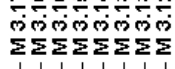

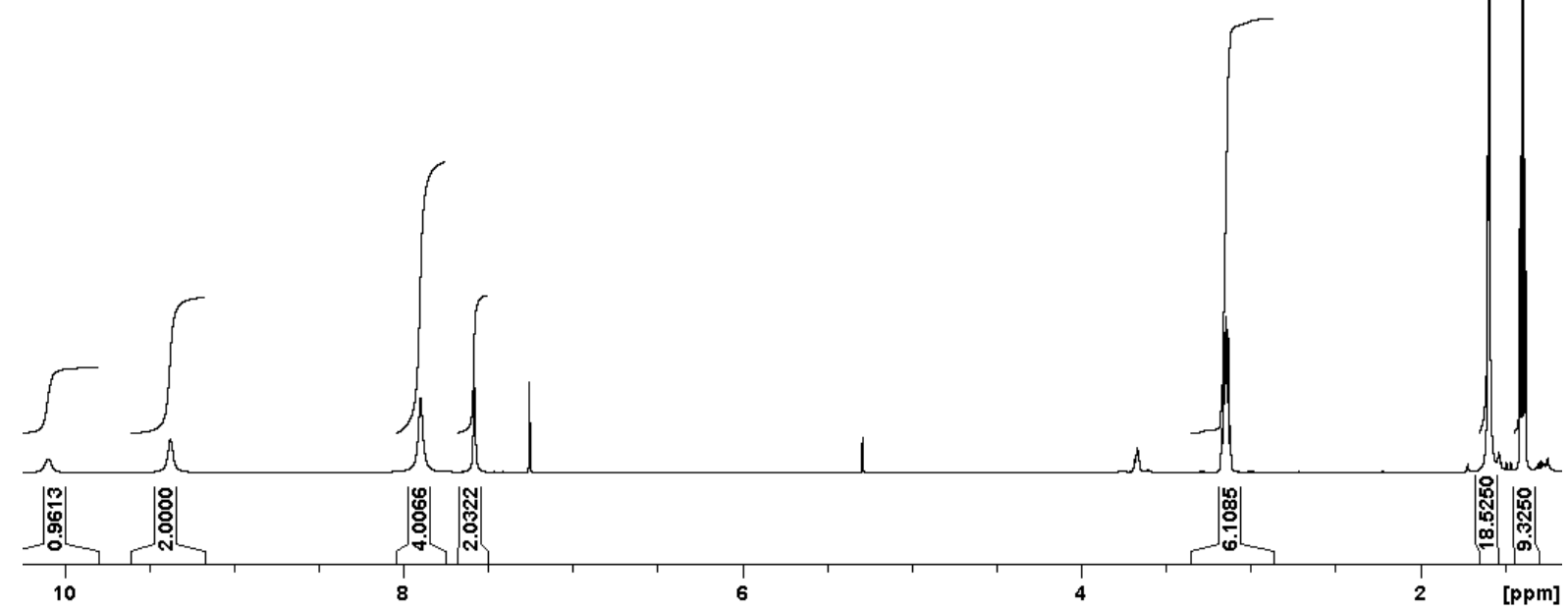

Figure S 9: ${ }^{1} \mathrm{H}$ NMR spectrum $\left(25^{\circ} \mathrm{C}, \mathrm{CD}_{3} \mathrm{Cl}, 500.12 \mathrm{MHz}\right)$ of $1 \mathrm{C} \cdot(\mathrm{AuCl})_{2} \cdot \mathrm{Et}{ }_{3} \mathrm{NHCl}$.

$$
\text { 六 }
$$

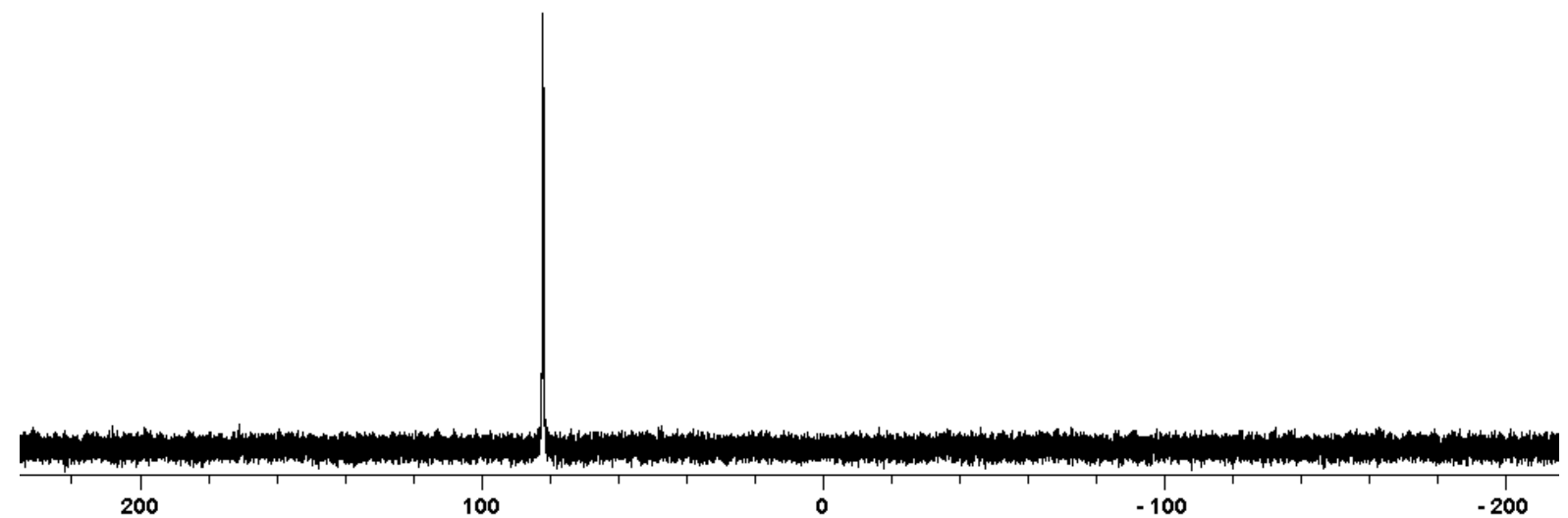

Figure S 10: ${ }^{31} \mathrm{P} N \mathrm{NR}$ spectrum $\left(25^{\circ} \mathrm{C}, \mathrm{CD}_{3} \mathrm{Cl}, 202.48 \mathrm{MHz}\right)$ of $1 \mathrm{C} \cdot(\mathrm{AuCl})_{2} \cdot \mathrm{Et} \mathrm{t}_{3} \mathrm{NHCl}$. 


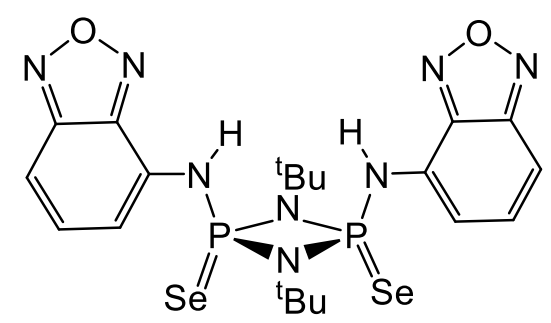

Synthesis of 4: Inside a $\mathrm{N}_{2}$ filled glovebox a Schlenk tube was charged with $\left[\mathrm{P}\left(\mu-\mathrm{N}^{\mathrm{t}} \mathrm{Bu}\right) \mathrm{Cl}\right]_{2}(275 \mathrm{mg}$, $1 \mathrm{mmol}$ ) and 4-amino-benzoxadiazole (316 $\mathrm{mg}, 4 \mathrm{mmol}$, 2 equivalents) and transferred to a Schlenk line. $20 \mathrm{ml}$ of THF and $5 \mathrm{ml}$ dry $\mathrm{NEt}_{3}$ were added and the resulting suspension was stirred overnight at $50^{\circ} \mathrm{C}$. Afterwards Selenium (316mg, $4 \mathrm{mmol}, 4$ equivalents) was added and the mixture was stirred or $72 \mathrm{~h}$ at room temperature. The solvent was removed in vacuo and resulting solid mixture was extracted with $20 \mathrm{ml} \mathrm{CH}_{2} \mathrm{Cl}_{2}$. The solvent was removed in vacuo to yield 4 as a yellow powder (587mg, $0.93 \mathrm{mmol}, 97 \%)$.

${ }^{1} \mathrm{H}$ NMR $\left(25^{\circ} \mathrm{C}, \mathrm{CD}_{3} \mathrm{Cl}, 500.12 \mathrm{MHz}\right): \delta[\mathrm{ppm}]=7.85\left(\mathrm{~d},{ }^{3} \mathrm{~J}_{\mathrm{HH}}=6.8 \mathrm{~Hz}, 2 \mathrm{H}, \mathrm{Ar}\right), 7.63-7.45(\mathrm{~m}, 4 \mathrm{H}, \mathrm{Ar})$, $6.74(\mathrm{~s}, 2 \mathrm{H}, \mathrm{NH}), 1.61\left(\mathrm{~s}, 18 \mathrm{H},{ }^{\mathrm{t}} \mathrm{Bu}\right)$.

${ }^{31} \mathrm{P}$ NMR $\left(25^{\circ} \mathrm{C}, \mathrm{CD}_{3} \mathrm{Cl}, 202.48 \mathrm{MHz}\right): \delta[\mathrm{ppm}]=27.7$ (s, with two satellite doublets arising from $\left.\left[\left({ }^{77} \mathrm{Se}=\right) \mathrm{HRN}-\mathrm{P}\left(\mu-\mathrm{N}^{\mathrm{t} B u}\right) \mathrm{P}-\mathrm{NRH}(=\mathrm{Se})\right],{ }^{1} \mathrm{~J}_{\mathrm{PS}}=929 \mathrm{~Hz},{ }^{2} \mathrm{~J}_{\mathrm{PP}}=25 \mathrm{~Hz}\right)$.

Elemental analysis (\%) calcd. for 4: calcd C 39.9\% H 4.3\% N 14.0\%, found C 37.7\% H 4.6\% N 15.5\%: Despite repeated attempts, we were unable to obtain satisfactory $\mathrm{N}$ and $\mathrm{C}$ contents. This is a common observation for phosphazane compounds. ${ }^{3}$
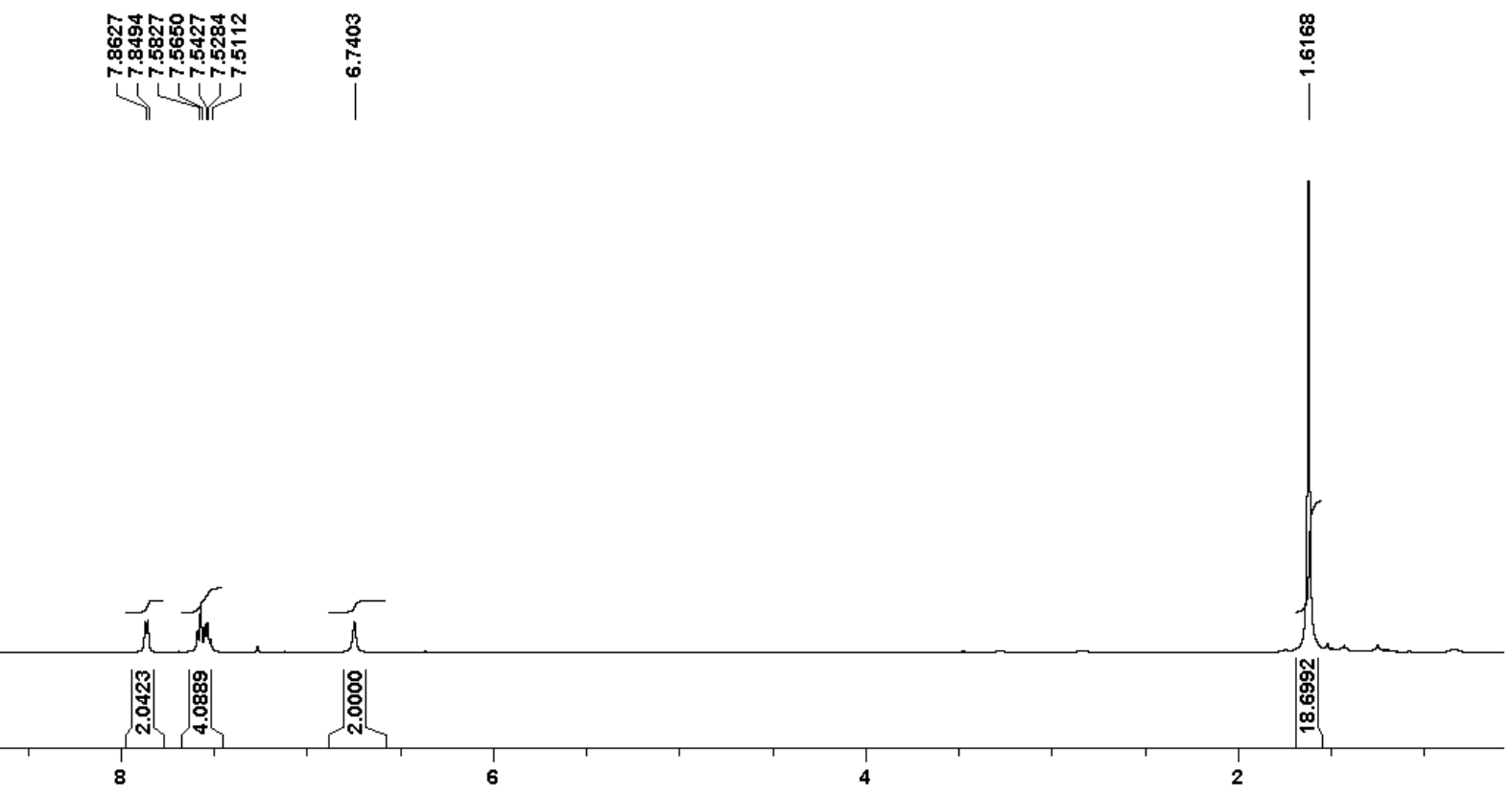

Figure $\mathrm{S} 11:{ }^{1} \mathrm{H}$ NMR spectrum $\left(25^{\circ} \mathrm{C}, \mathrm{CD}_{3} \mathrm{Cl}, 500.12 \mathrm{MHz}\right)$ of 4 . 


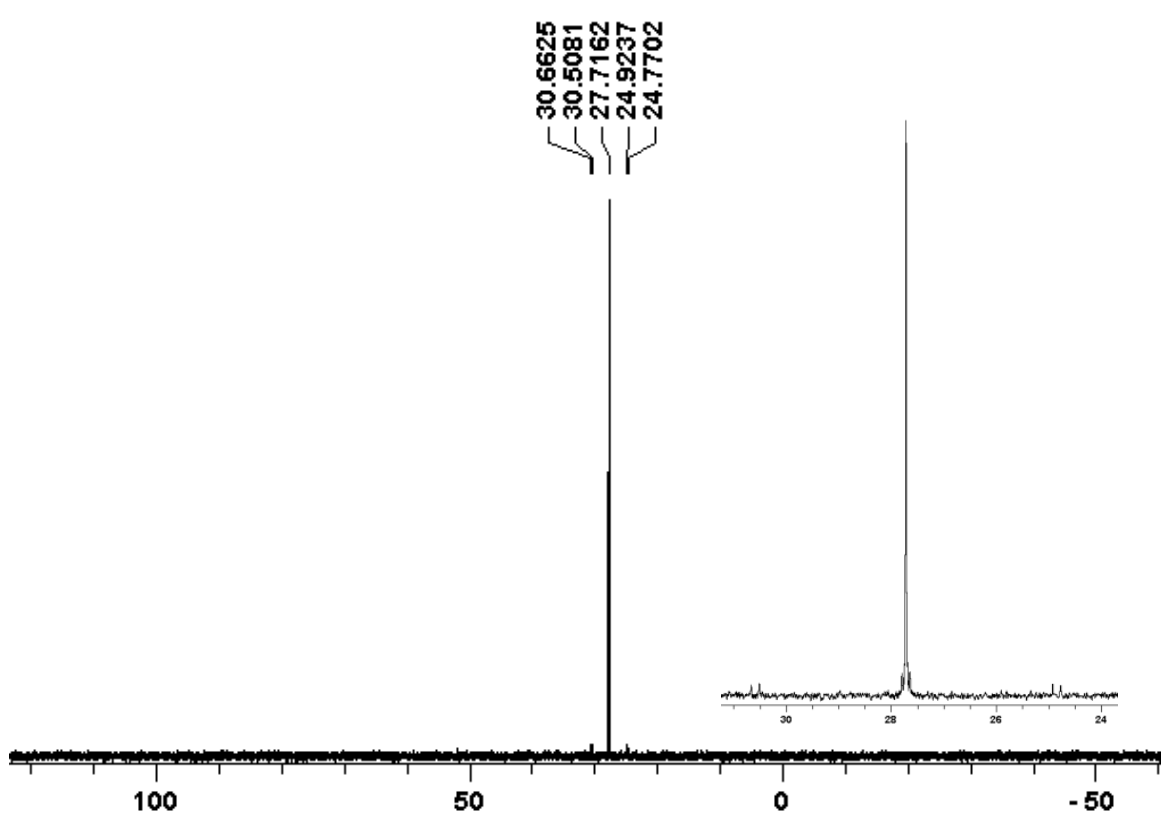

Figure S 12: ${ }^{31} \mathrm{P} N \mathrm{NR}$ spectrum $\left(25^{\circ} \mathrm{C}, \mathrm{CD}_{3} \mathrm{Cl}, 202.48 \mathrm{MHz}\right)$ of 4.

\section{References Synthesis}

(1) Chivers, T.; Krahn, M.; Parvez, M.; G. Schatte Inorg. Chem. 2001, 40, 2547-2553.

(2) Roth, T.; Wadepohl, H.; Wright, D. S.; Gade, L. H. Chem. Eur. J. 2013, 19, 13823-13837.

(3) Benson, C. G. M.; Vasilenko, V.; García-Rodríguez, R.; Bond, A. D.; González Calera, S.; Gade, L. H.; Wright, D. S.; Doyle, E. L.; Riera, L.; Wright, D. S. Dalton Trans. 2015, 44, 14242-14247.

(4) Lief, G. R.; Carrow, C. C.; Moser, D. F.; Stahl, L. Phosphorus. Sulfur. Silicon Relat. Elem. 2001, 168, 157-162.

(5) Oi, S.; Kashiwagi, K.; Inoue, Y. A. Tetrahedron Lett. 1998, 39, 6253-6256.

(6) Manzur, J.; Vega, A.; García, A. M.; Acuña, C.; Sieger, M.; Sarkar, B.; Niemeyer, M.; Lissner, F.; Schleid, T.; Kaim, W. Eur. J. Inorg. Chem. 2007, 5500-5510. 


\section{Binding Constants and NMR Titrations}

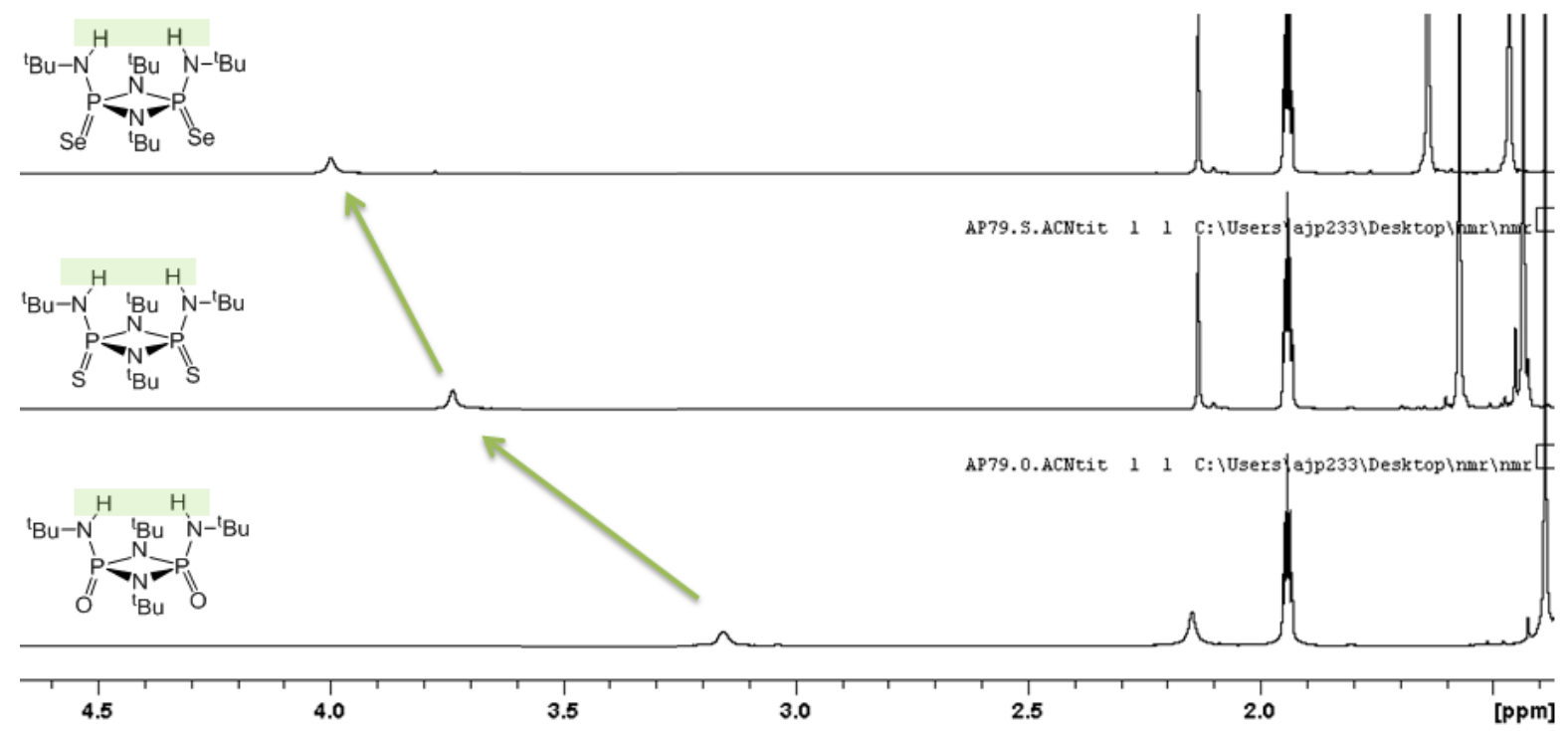

Figure S 13: ${ }^{1} \mathrm{H}$ NMR spectra of $3 a, 3 b, 3 c\left(25^{\circ} \mathrm{C}, \mathrm{CD}_{3} \mathrm{CN}, 500.12 \mathrm{MHz}, 6.6 \mathrm{mM}\right)$. The down-field trend in the $\mathrm{N}-\mathrm{H}$ chemical shift in highlighted.
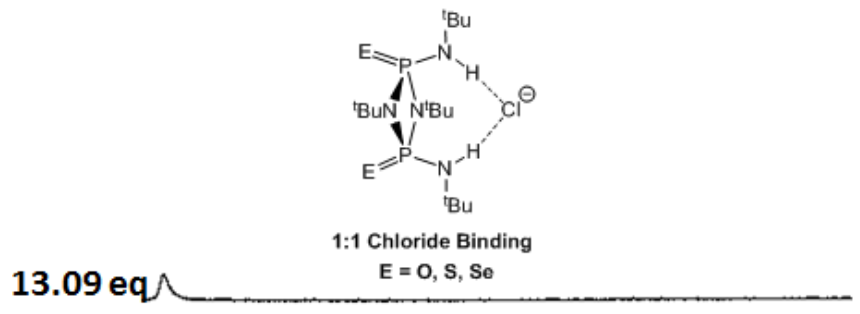

\section{$9.24 \mathrm{eq} \wedge$}

$6.16 \mathrm{eq}$

$3.01 \mathrm{eq}$
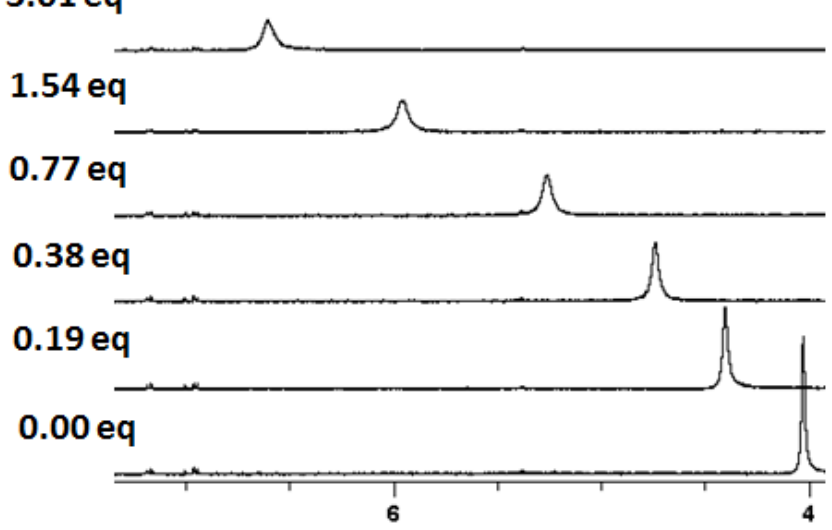

Figure S 14: Titration of tetrabutylammoniumchloride into a $6.6 \mathrm{mM}$ solution of $3 \mathrm{c}$ in $C D_{3} \mathrm{CN}$. Zoomed in on the NH peak in ${ }^{1} \mathrm{H}$ NMR spectrum $\left(25^{\circ} \mathrm{C}, \mathrm{CD}_{3} \mathrm{CN}, 500.12 \mathrm{MHz}\right)$. For $\mathrm{E}=\mathrm{O}, \mathrm{S}$ similar shift range was observed. 

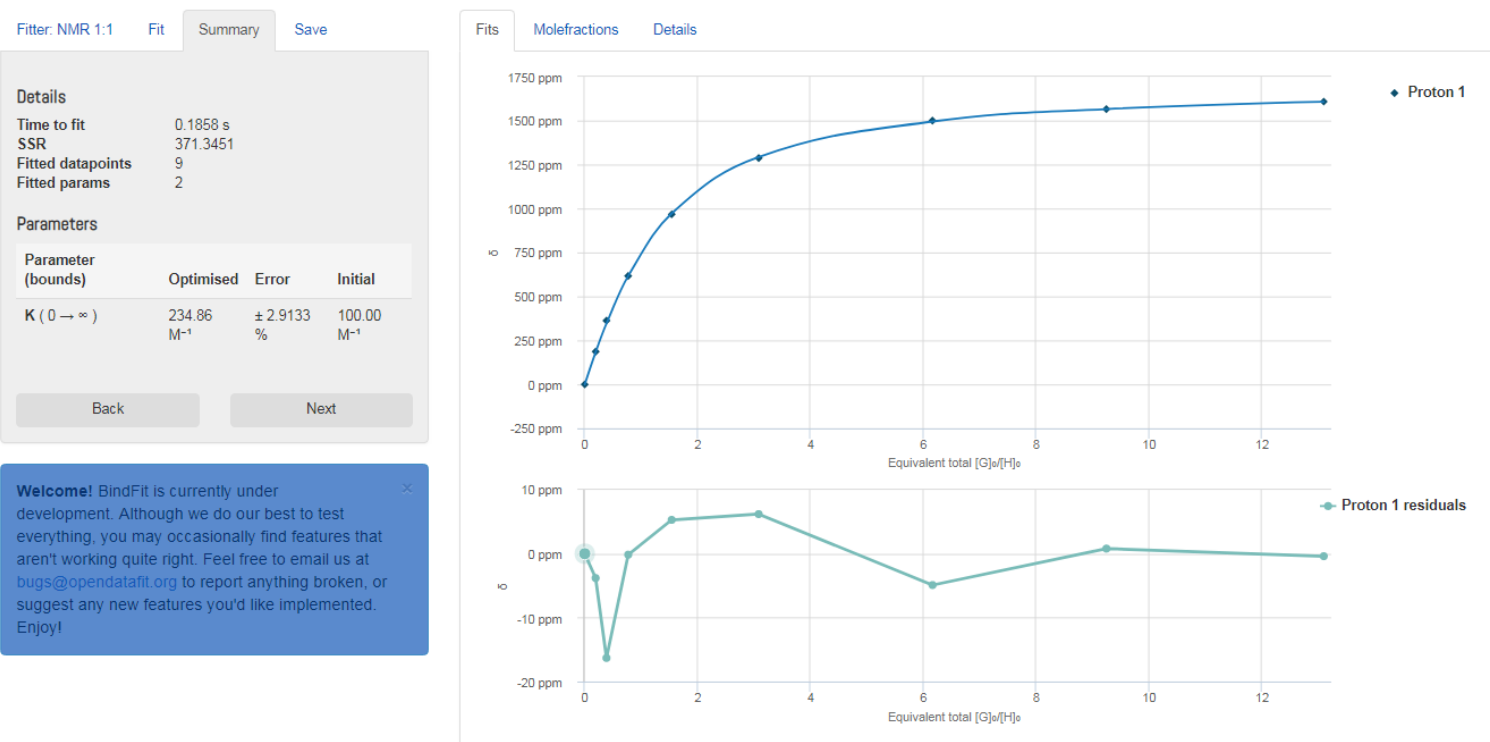

Figure S 15: Binding isotherm (1:1 system) fitted to the ${ }^{1} \mathrm{H}$ NMR chemical shift of the NH protons in 3c (y Axis in $\mathrm{Hz}$ not ppm) vs. the equivalents of ${ }^{n} \mathrm{BuNCl}$ added (top). The residual plot from the fit (bottom).
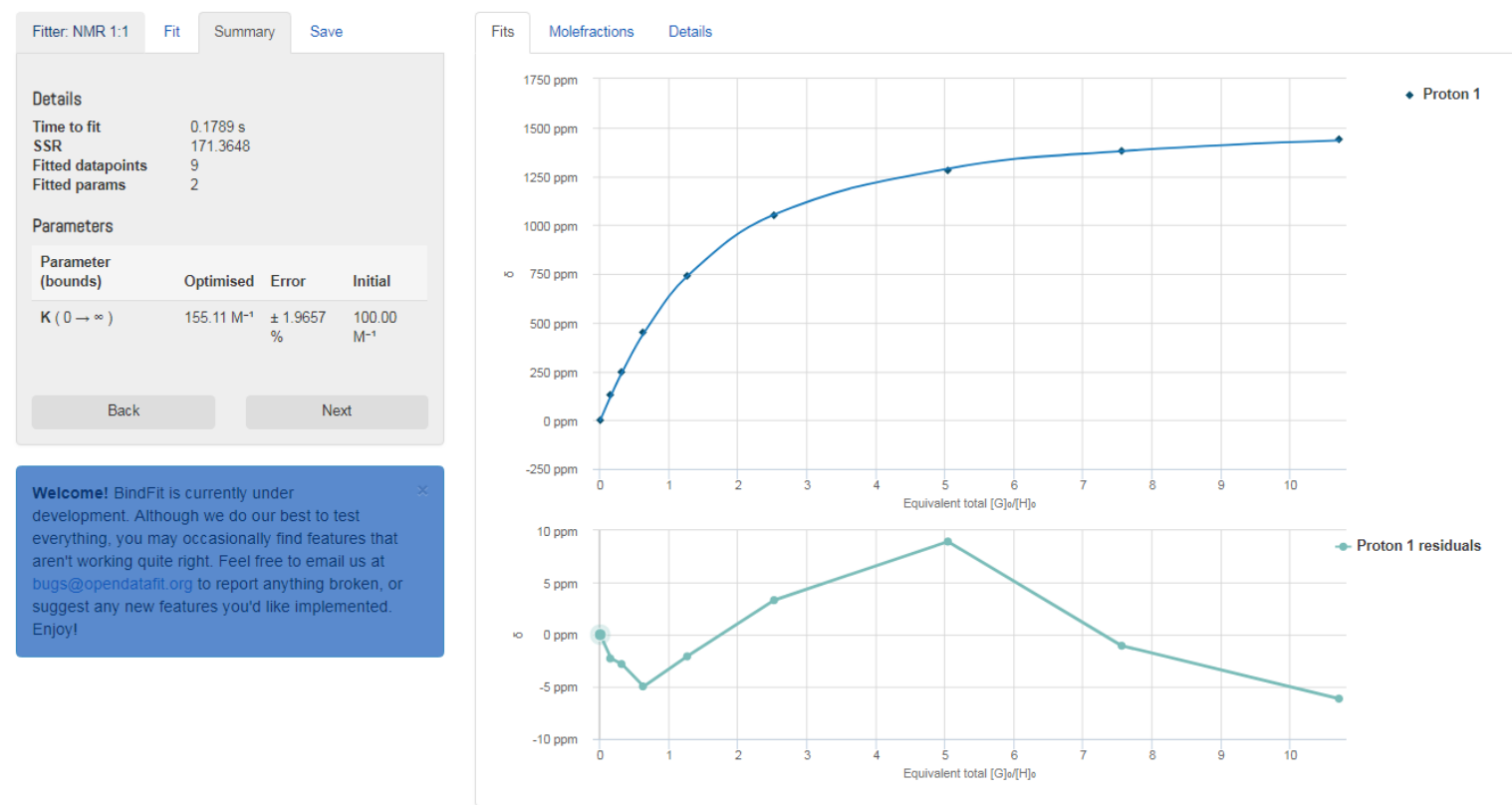

Figure S 16: Binding isotherm (1:1 system) fitted to the ${ }^{1} \mathrm{H}$ NMR chemical shift of the NH protons in $3 \boldsymbol{b}$ (y Axis in Hz not ppm) vs. the equivalents of ${ }^{n} \mathrm{BuNCl}$ added (top). The residual plot from the fit (bottom). 

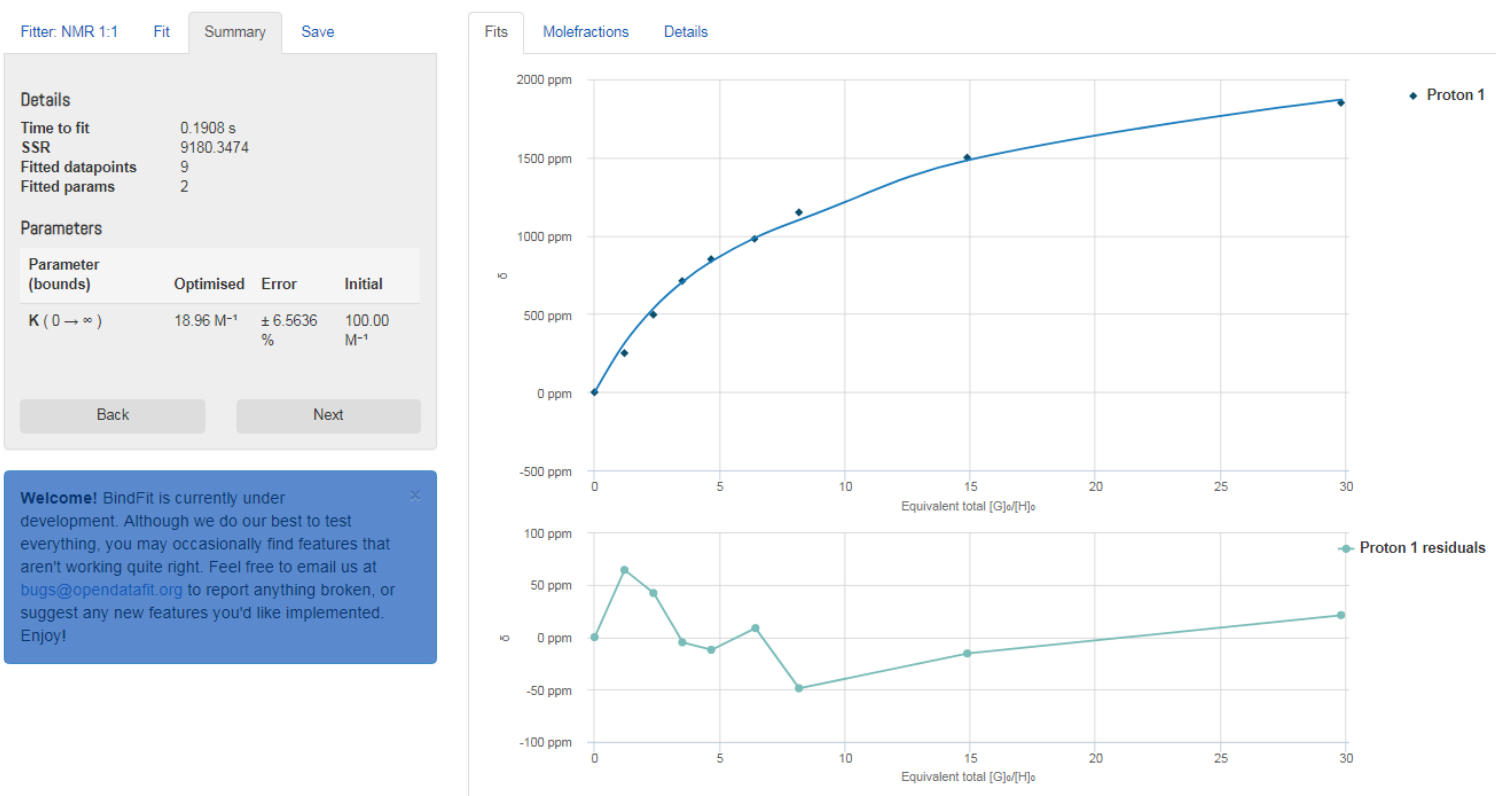

Figure S 17: Binding isotherm (1:1 system) fitted to the ${ }^{1} \mathrm{H} N \mathrm{NM}$ chemical shift of NH protons in $3 a$ ( $y$ Axis in $\mathrm{Hz}$ not ppm) vs. the equivalents of ${ }^{n} \mathrm{BuNCl}$ added to determine (top). The residual plot from the fit (bottom).

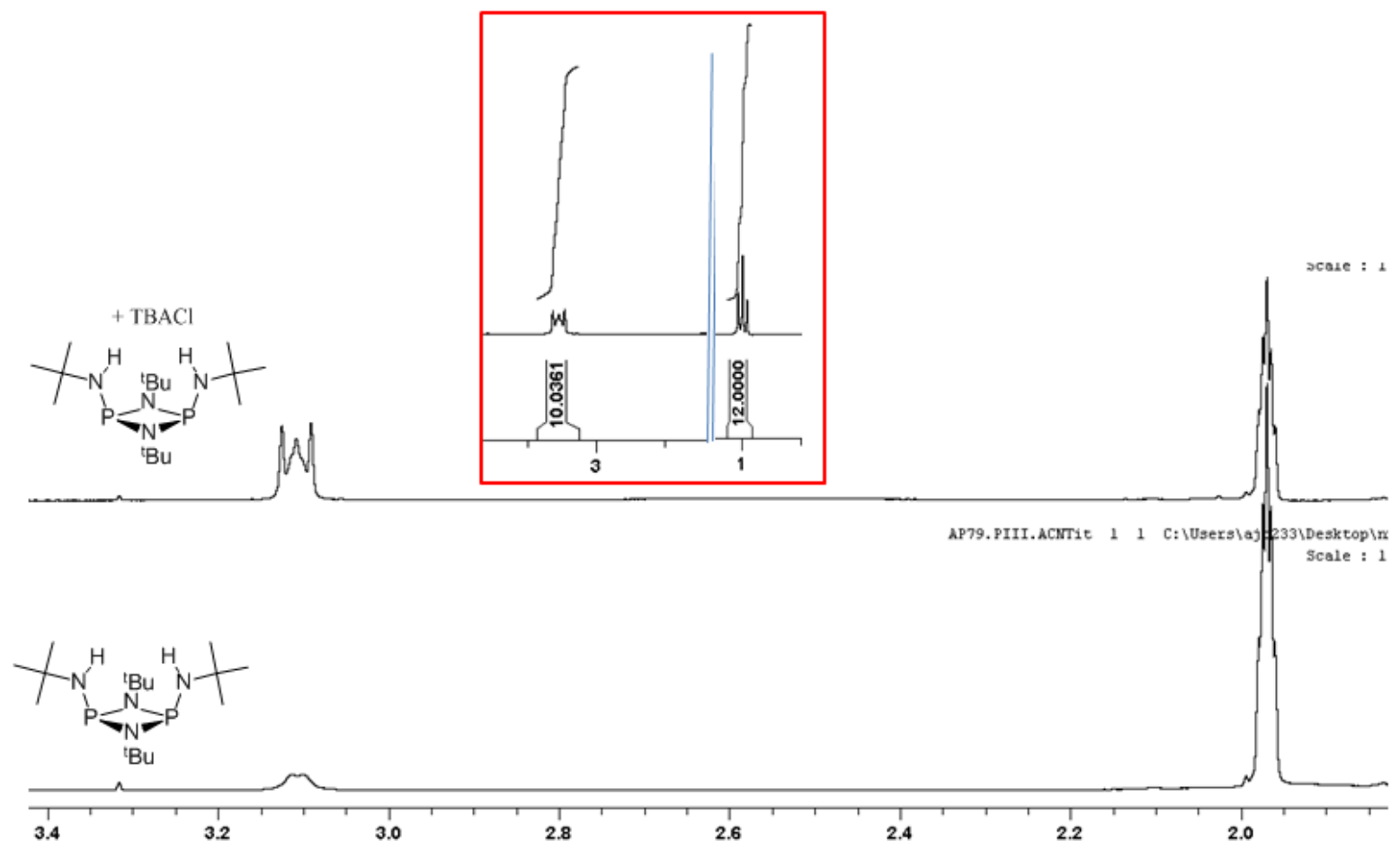

Figure S 18: ${ }^{1} \mathrm{H} N M R$ spectra of $\left[\mathrm{P}\left(\mu-\mathrm{N}^{t} \mathrm{Bu}\right) \mathrm{NH}^{t} \mathrm{Bu}\right]_{2}\left(\mathrm{CD}_{3} \mathrm{CN}, 25^{\circ} \mathrm{C}, 400 \mathrm{MHz}\right)$ upon addition of 1 eqTBACl. TBA methyelene peak overlaps with $\mathrm{NH}$ peak, which was confirmed via integration (see inlayed box) supporting minimal interaction between $\left[P\left(\mu-N^{t} B u\right) N^{t} B u\right]_{2}$ and chloride. 


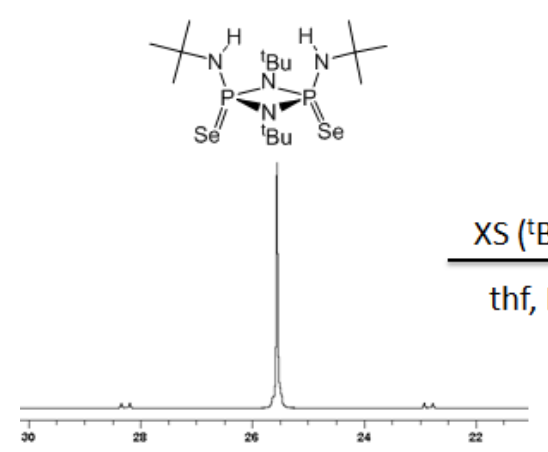

$\left({ }^{\mathrm{t}} \mathrm{Bu}\right)_{3} \mathrm{P}=\mathrm{Se}$
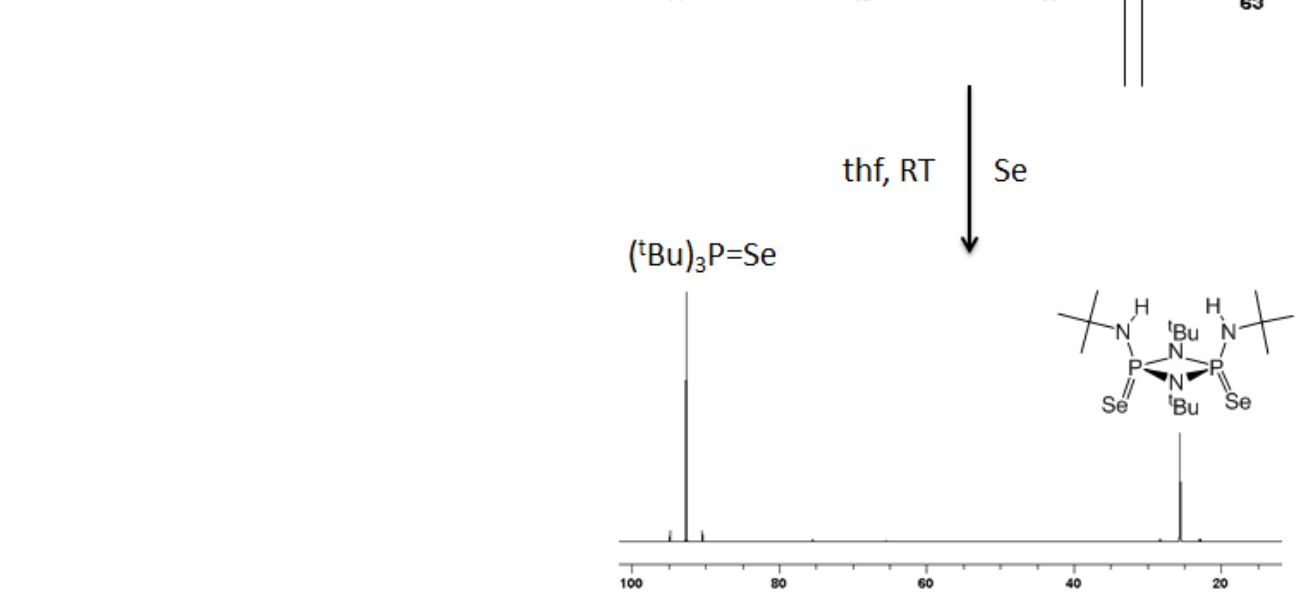

Figure S 19: Reduction/oxidation cycle of $3 c$ with ${ }^{t} B u_{3} P$ then selenium added, monitored by ${ }^{31} P$ NMR spectroscopy $\left(25^{\circ} \mathrm{C}, d_{8^{-}}\right.$ thf, $202.48 \mathrm{MHz}$ ) in the presence of chloride (in the form of $\mathrm{LiCl}$ ).

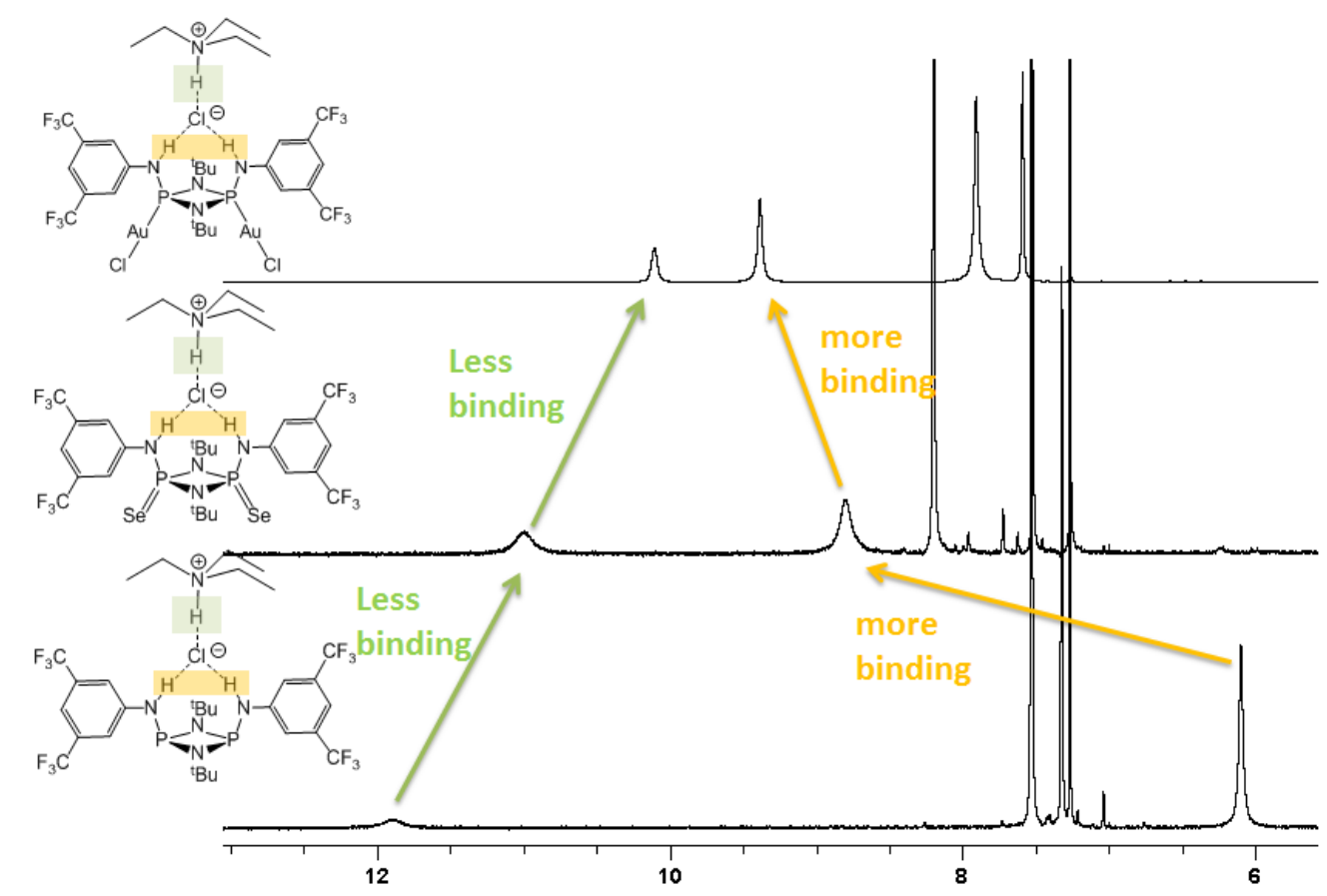

Figure S 20: ${ }^{1} \mathrm{H}$ NMR spectra of A-1.Et ${ }_{3} \mathrm{NHCl}, 1 \mathrm{c} \cdot \mathrm{Et}_{3} \mathrm{NHCl}$ and $1 \mathrm{c} \cdot(\mathrm{AuCl}){ }_{2} \cdot \mathrm{Et}_{3} \mathrm{NHCl}\left(25^{\circ} \mathrm{C}, \mathrm{CD}_{3} \mathrm{Cl}, 500 \mathrm{MHz}\right)$. 


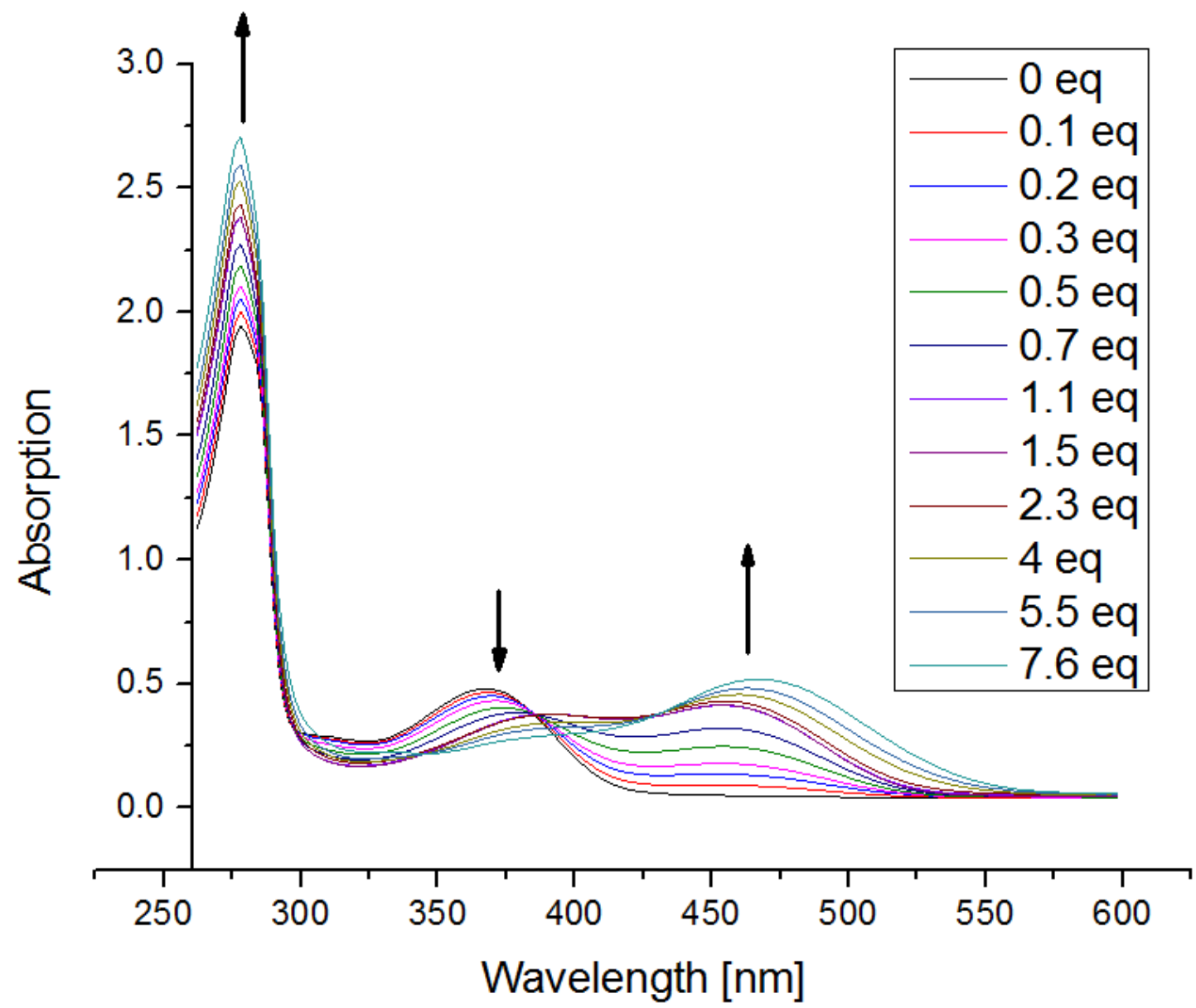

Figure S 21: UV-VIS titration of a $27.5 \mu \mathrm{M}$ solution of 4 in $\mathrm{CH}_{3} \mathrm{CN}$ with Tetrabutylammoniumflouride.

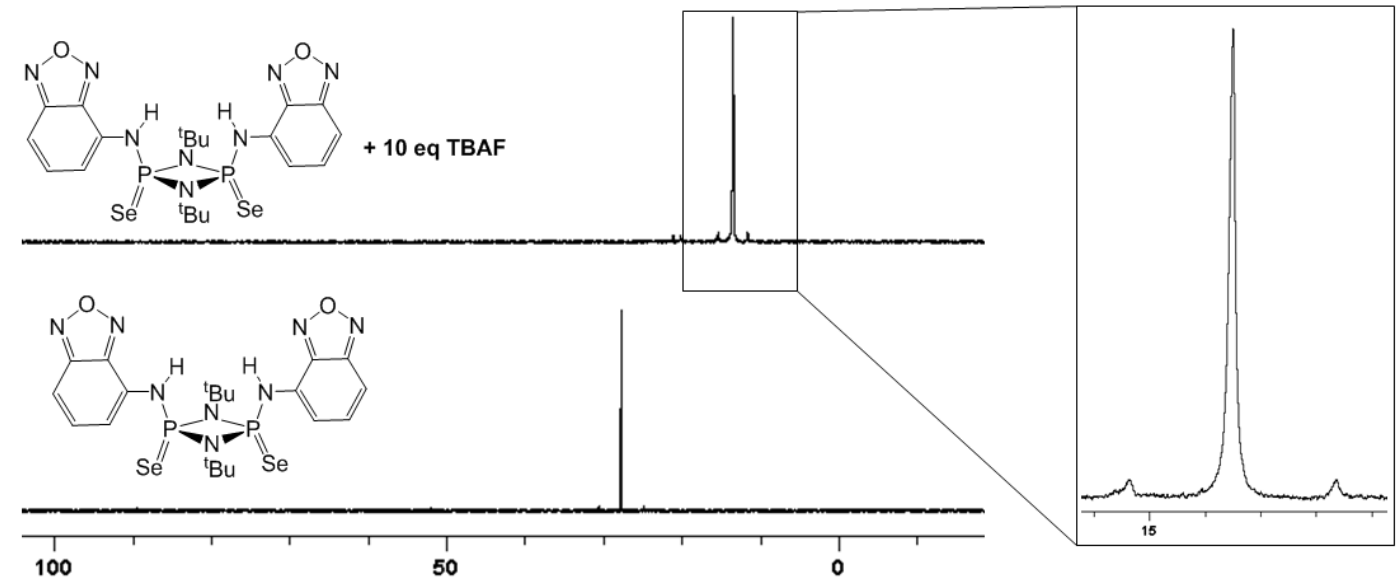

Figure S 22: ${ }^{31} \mathrm{P} N \mathrm{MR}$ spectra $\left(25^{\circ} \mathrm{C}, \mathrm{CDCl}_{3}, 202.48 \mathrm{MHz}\right.$ ) of 4 before and after the addition of 10 eq TBAF (applied as a $1 \mathrm{M}$ stock solution in THF). 


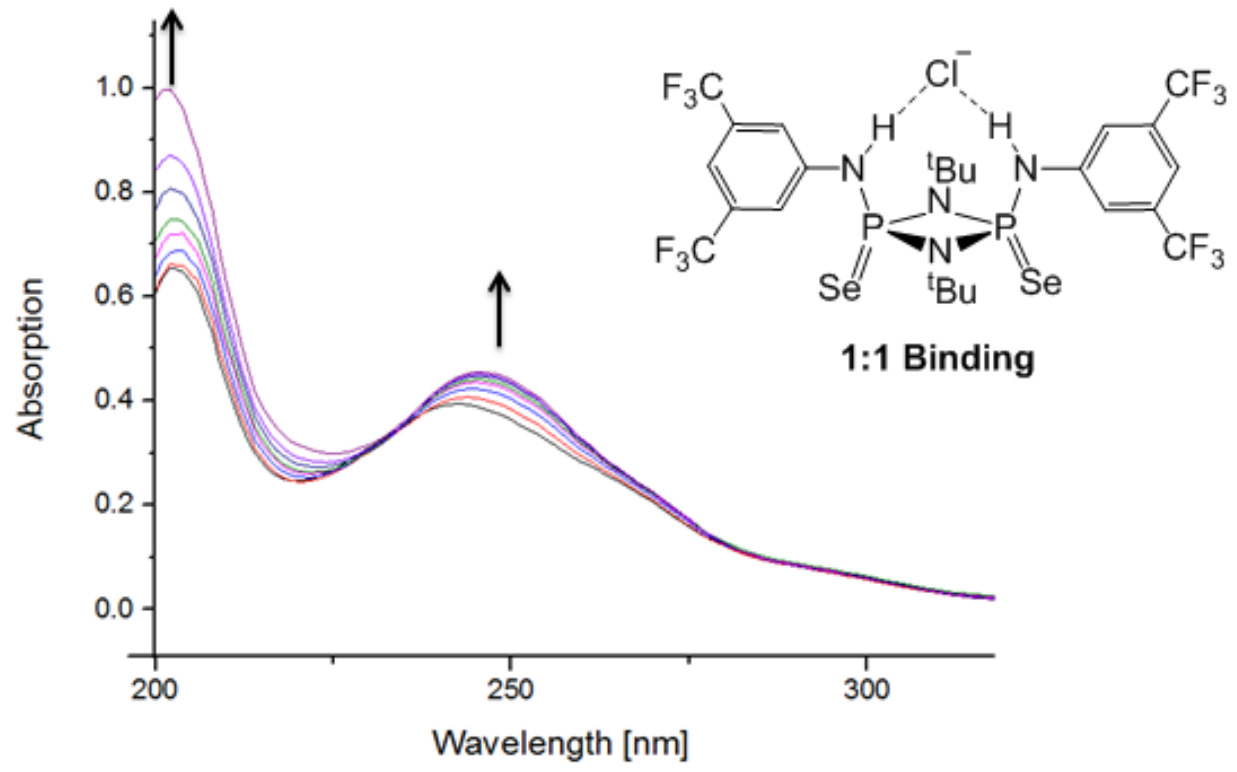

Figure S 23: UV-Vis titration of ${ }^{n} \mathrm{Bu}_{4} \mathrm{NCl}$ into a $1.46 * 10^{-5} \mathrm{M}$ solution of $1 \mathrm{c}$ in $\mathrm{CH}_{3} \mathrm{CN}$ at $298 \mathrm{~K}$ : only every second spectrum recorded is shown for clarity.
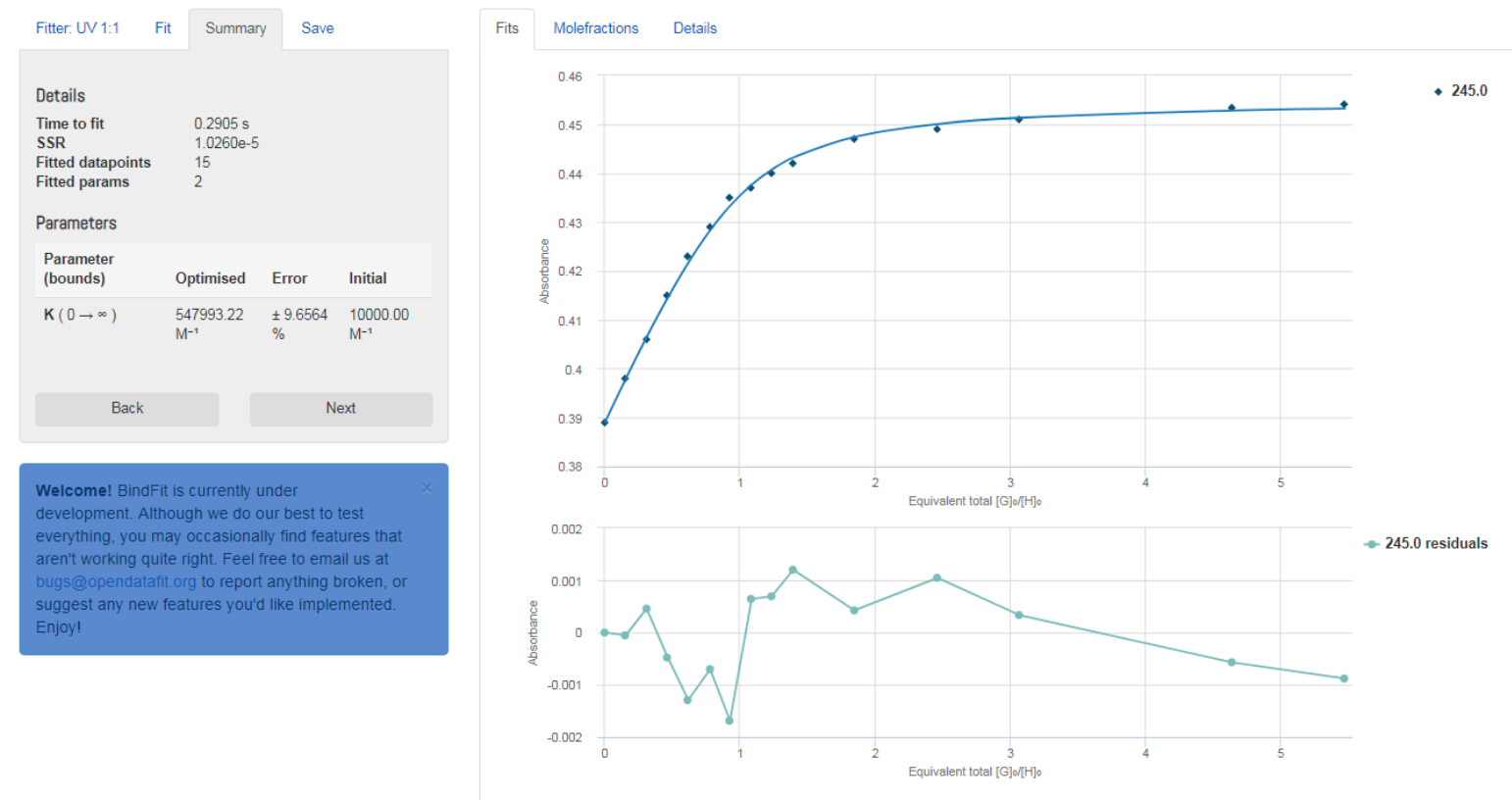

Figure S 24: Binding isotherm (1:1 system) fitted to the absorbance of the band at $250 \mathrm{~nm}$ in 1c vs. the equivalents of ${ }^{n} \mathrm{Bu}_{4} \mathrm{NCl}$ added (top). The residual plot from the fit (bottom). 


\title{
3. Ion-Transport Studies
}

\author{
Abbreviations \\ POPC: 2-oleoyl-1-palmitoyl-sn-glycero-3-phosphocholine; \\ HPTS: 8-hydroxypyrene-1,3,6-trisulfonic acid; \\ PB: phosphate buffer; \\ SUVs: small unilamellar vesicles; \\ FI: fluorescence intensity.
}

\section{Experiment de tails}

\section{Mate rials}

POPC for vesicle preparation were purchased from Avanti Polar Lipids. HPTS, lucigenin and Sephadex G-50 were purchased from Sigma. Fluorescence measurements were performed on a Cary Eclipse Fluorescence Spectrophotometer (Agilent).

\section{2. $\mathrm{Cl}^{-}$trans port activity studied by lucige nin assay}

\subsection{Preparation of POPC-SUVs $\supset$ lucigenin}

A thin lipid film in a glass vial was obtained by evaporating $0.4 \mathrm{~mL}$ of POPC $(20 \mathrm{mg} / \mathrm{mL}$ in chloroform) under reduced pressure on a rotary evaporator at $45{ }^{\circ} \mathrm{C}$ and then in high vacuum under room temperature for $1 \mathrm{~h}$. For cholesterol test, $0.4 \mathrm{~mL}$ of 7:3 mixture of POPC and cholesterol in chloroform was used instead of pure POPC. $0.4 \mathrm{~mL}$ of PB (phosphate buffer) with lucigenin (1 mM lucigenin, $5 \mathrm{mM}$ sodium phosphate, $225 \mathrm{mM} \mathrm{NaNO}_{3}, \mathrm{pH} 7.5$ ) was added to rehydrate the lipid film. The resulting suspension was subjected to 5 freeze/thaw cycles and extruded through a polycarbonate membrane (pore size $200 \mathrm{~nm}$ ) for 29 times. Unencapsulated lucigenin was removed by a Sephadex (G-50) column, and finally about $0.9 \mathrm{~mL}$ of POPC-SUVs lucigenin solution $(\sim 11.6 \mathrm{mM}$ POPC; solution in the liposomes: $1 \mathrm{mM}$ lucigenin, $5 \mathrm{mM}$ sodium phosphate, $225 \mathrm{mM} \mathrm{NaNO}_{3}, \mathrm{pH}=7.5$ ) was gained.

For the preparation of $\mathrm{NaCl}$ contained POPC-SUVs $\supset$ lucigenin, $0.4 \mathrm{~mL}$ of $\mathrm{PB}$ with $\mathrm{NaCl}$ and lucigenin (1 mM lucigenin, $5 \mathrm{mM}$ sodium phosphate, $100 \mathrm{mM} \mathrm{NaCl}, \mathrm{pH} 7.5$ ) was used to rehydrate the lipid film. The other procedure was the same as above and a final volume of around $0.9 \mathrm{~mL}$ of POPC-SUVs $\supset$ lucigenin solution $(\sim 11.6 \mathrm{mM}$ POPC; solution in the liposomes: $1 \mathrm{mM}$ lucigenin, 5 $\mathrm{mM}$ sodium phosphate, $100 \mathrm{mM} \mathrm{NaCl}, \mathrm{pH}=7.5$ ) was gained. 


\section{2 $\mathrm{Cl}^{-}$transport across POPC-SUVs $\supset$ lucigenin}

The schematic diagram of lucigenin assay is shown in Scheme SXX. $30 \mu \mathrm{L}$ of vesicle solution mixed with $970 \mu \mathrm{L}$ of $\mathrm{PB}\left(5 \mathrm{mM}\right.$ sodium phosphate, $\mathrm{pH}=7.5,225 \mathrm{mM} \mathrm{NaNO}_{3}$ or $100 \mathrm{mM}$ other salt $)$ were mixed in a dry cuvette. $5 \mu \mathrm{L}$ of $4 \mathrm{M} \mathrm{NaCl}$ was added to the extravesicular buffer to induce a $20 \mathrm{mM}$ chloride gradient across the lipid membrane at $t=0.5 \mathrm{~min}$ after the start of the recording, and $10 \mu \mathrm{L}$ anion carrier molecule in acetonitrile was added at $t=1.5 \mathrm{~min}$ to initiate the transport. $20 \mu \mathrm{L}$ of 10 wt $\%$ Triton X-100 was added to lyse the vesicles for calibration at $t=6 \mathrm{~min}$. The change of fluorescence intensity of the lucigenin with time was recorded at $505 \mathrm{~nm}$ with the excitation wavelength of $455 \mathrm{~nm}$. Fluorescence time courses of lucigenin were also normalized to fractional emission intensity $I_{\mathrm{t}}$ according to equation [E1]:

$$
I_{\mathrm{t}}=\left(F_{\mathrm{t}}-F_{\infty}\right) /\left(F_{0}-F_{\infty}\right) \quad[\mathrm{E} 1],
$$

where $F_{\mathrm{t}}$ is fluorescence intensity at time $\mathrm{t}, F_{0}=F_{\mathrm{t}}$ before addition of $\mathrm{NaCl}$ and $F_{\infty}=F_{\mathrm{t}}$ after complete leakage with Triton X-100.

\section{Ion transport activity studied by HPTS ass ay}

\subsection{Pre paration of POPC-SUVs $\supset$ HPTS}

A thin lipid film was gained by evaporating $0.4 \mathrm{~mL}$ of POPC $(20 \mathrm{mg} / \mathrm{mL}$ in chloroform) under reduced pressure on a rotary evaporator at $45{ }^{\circ} \mathrm{C}$ and then in high vacuum under room temperature for 1h. After that the lipid film was rehydrated with $0.4 \mathrm{~mL}$ HEPES buffer containing HPTS ( $1 \mathrm{mM}$ HPTS, $10 \mathrm{mM}$ HEPES, $100 \mathrm{mM} \mathrm{NaCl}$, pH 6.7) by vortexing and then sonicated for $15 \mathrm{~min}$. Subsequently, the resulting suspension was subjected to 5 freeze/thaw cycles and extruded through a polycarbonate membrane (pore size $200 \mathrm{~nm}$ ) for 29 times. Finally, the unencapsulated HPTS was removed by a Sephadex (G-50) column and a final volume of around $0.9 \mathrm{~mL}$ of POPC-SUVs solution ( 11.6 mM POPC; solution inside liposomes: $1 \mathrm{mM}$ HPTS, $10 \mathrm{mM}$ HEPES, $100 \mathrm{mM} \mathrm{NaCl}$, $\mathrm{pH}=6.7$; solution outside liposomes: $10 \mathrm{mM}$ HEPES, $100 \mathrm{mM} \mathrm{NaCl}, \mathrm{pH}=6.7$ ) was obtained.

\subsection{Ion trans port activity studied across POPC-SUVs $\supset$ HPTS}

The schematic diagram of HPTS assay is shown in Scheme S34. $10 \mu \mathrm{L}$ of POPC-SUVs $\supset$ HPTS solution prepared as described above and $990 \mu \mathrm{L}$ of HEPES buffer (10 mM HEPES, $100 \mathrm{mM} \mathrm{NaCl}$, $\mathrm{pH}$ 6.7) were mixed in a dry cuvette. $8.5 \mu \mathrm{L}$ of $0.5 \mathrm{M} \mathrm{NaOH}$ was added into the extravesicular buffer to induce a $\mathrm{pH}$ gradient $(\Delta \mathrm{pH}=0.8)$ across the lipid membrane at $t=0.5$ min after the start of the recording, anion carrier molecule ( $20 \mu \mathrm{L}$ in acetonitrile at varied concentration) was added to initiate the ion transport at $t=1.5 \mathrm{~min}$, and $20 \mu \mathrm{L}$ of $10 \mathrm{wt} \%$ Triton $\mathrm{X}-100$ was added to lyse the vesicles for calibration at $t=6 \mathrm{~min}$. The change of fluorescence intensity of the HPTS with time was recorded at $510 \mathrm{~nm}$ with the excitation wavelength of $450 \mathrm{~nm}$. Fluorescence time courses were normalized to fractional emission intensity $I_{\mathrm{t}}^{\prime}$ according to equation [E2].

$$
I_{\mathrm{t}}^{\prime}=\left(F_{\mathrm{t}}-F_{0}\right) /\left(F_{\infty}-F_{0}\right) \quad \text { [E2], }
$$

where $F_{\mathrm{t}}$ is fluorescence intensity at time $\mathrm{t}, F_{0}=F_{\mathrm{t}}$ before the addition of carrier molecule and $F_{\infty}=F_{\mathrm{t}}$ at saturation after complete leakage achieved with the $10 \mathrm{wt} \%$ Triton X-100. Fractional emission intensity $I_{\mathrm{t}}$ at $6 \mathrm{~min}$ (the time point before the addition of Trition X-100) were plotted as a function of carrier molecule concentration and fitted to the Hill equation [E3] to give the effective concentration 
$E C_{50}$ (the concentration of carrier molecule showing half activity respect to the maximum) and the Hill coefficient $n$.

$$
I=I_{\infty}+\left(I_{0}-I_{\infty}\right) /\left[1+\left(c / E C_{50}\right)^{n}\right] \quad[\mathrm{E} 3],
$$

Where $c$ is the concentration of carrier molecule, $I_{0}$ is fractional emission intensity without carrier molecule, and $I_{\infty}$ is fractional emission intensity with excess of carrier molecule.

As shown in Scheme S35, we changed the buffer solution inside or outside of the vesicles to study the transport mechanism and test its selectivity for different ions.

\section{Figures}

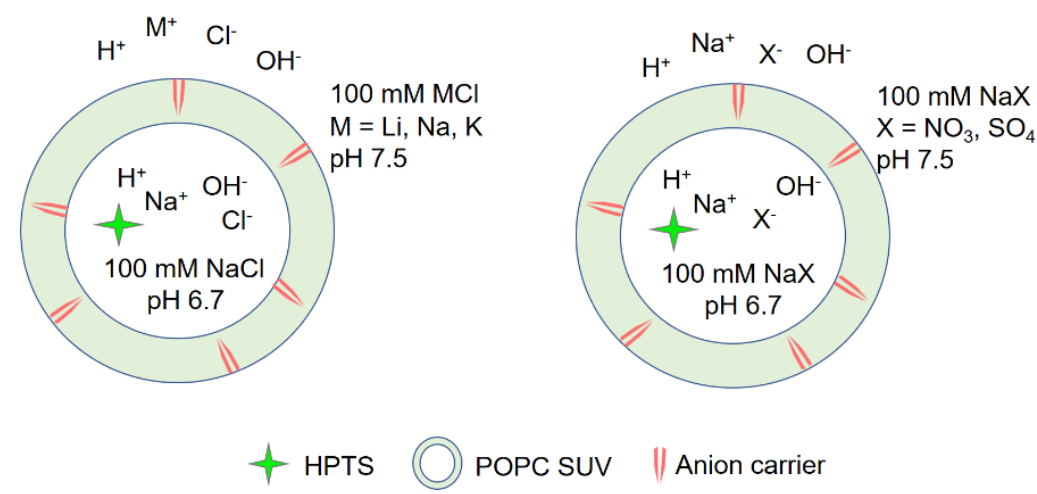

Figure S 25. Schematic diagram of the HPTS assay used to test the selectivity of carrier molecule for transport of cations (left) and anions (right) across the membrane.

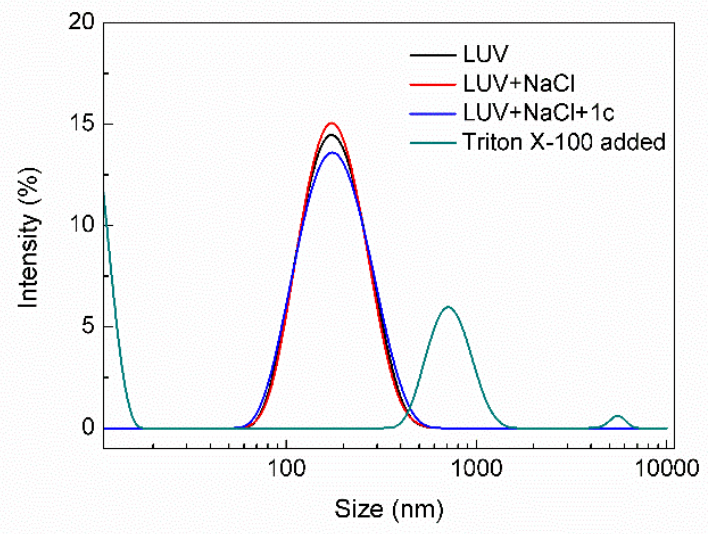

Figure S 26. Dynamic light scattering (DLS) spectra of POPC-LUVs Jlucigenin under different conditions. DLS spectra were collected after each addition ( $20 \mathrm{mM} \mathrm{NaCl}, 0.1 \mu \mathrm{MB}-1 \mathrm{c}, 0.2 \mathrm{wt} \%$ Triton X-100) into the extravesicular solution. Each data is from three repeated measurements. 


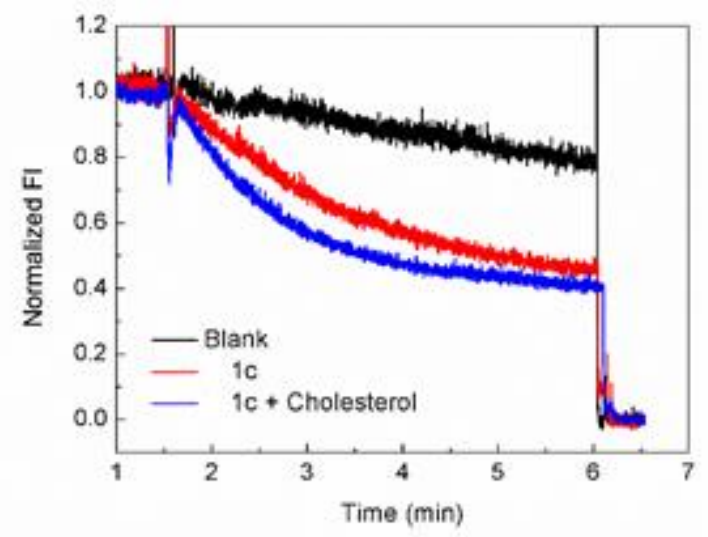

Figure S 27. Chloride influx into POPC-SUVs Jlucigenin with (blue curve) and without (red curve) cholesterol mediated by 0.1 MM AP121 as monitored by lucigenin assay. Unconclusive cholesterol essays for mobile carrier mechanism have been reported previously. ${ }^{7}$

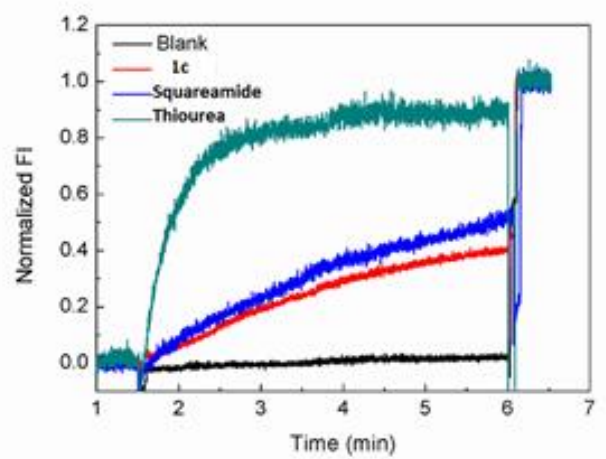

Figure S 28. Ion transport activity of different carrier molecules (10 nM) across POPC-SUVs دHPTS monitored by HPTS assay. $1 \mathrm{mMHPTS}$ was encapsulated in the SUVs and $\mathrm{NaOH}$ was added at $0.5 \mathrm{~min}$ to induce a $\mathrm{pH}$ gradient $(\Delta \mathrm{pH}=0.8)$ across the lipid membrane. Triton X-100 was added at 6 min to lyse the vesicles.
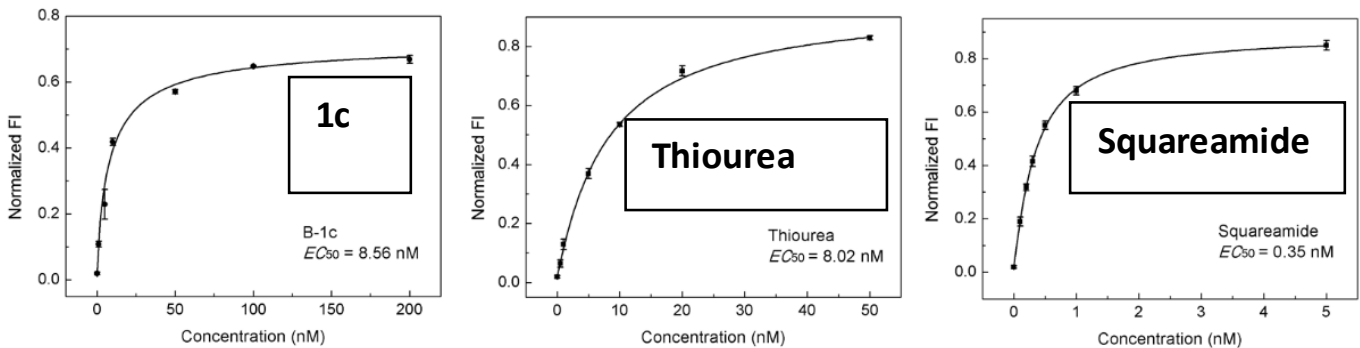

Figure S 29. Change of the normalized fluorescence intensity of HPTS at 6 min as a function of carrier molecule concentrations across POPC-SUVS $\mathrm{HHPTS}$. The data was collected from three repeated measurements. EC50 value for each carrier molecule gained from the Hill plot is given in the figure. 
a)

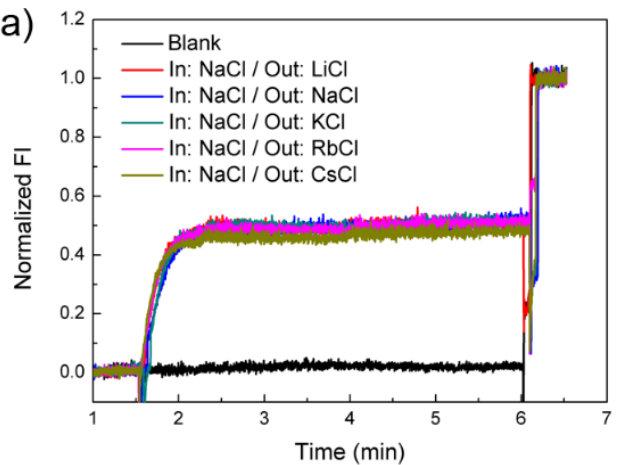

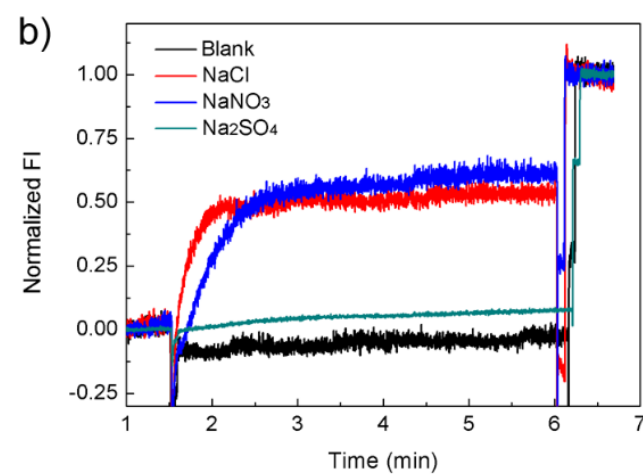

Figure S 30. Ion transport activity of $1 c(0.1 \mu \mathrm{M})$ across POPC-LUVs $\supset H P T S$ compared in different intravesicular and extravesicular solution conditions. a) Cation investigation. Inside: $100 \mathrm{mM} \mathrm{NaCl}, \mathrm{pH}$ 6.7, HEPES buffer; outside: $100 \mathrm{mM}$ $\mathrm{MCl}(\mathrm{M}=\mathrm{Li}, \mathrm{Na}, \mathrm{K}, \mathrm{Rb}, \mathrm{Cs}), \mathrm{pH} 7.5, \mathrm{HEPES}$ buffer. b) Anion investigation. Inside: $100 \mathrm{mMNaX}\left(\mathrm{X}=\mathrm{Cl}, \mathrm{NO}_{3}, \mathrm{SO}_{4}\right), \mathrm{pH}$ 6.7, HEPES buffer; outside: $100 \mathrm{mM} \mathrm{NaX,} \mathrm{pH} \mathrm{7.5,} \mathrm{HEPES} \mathrm{buffer.}$

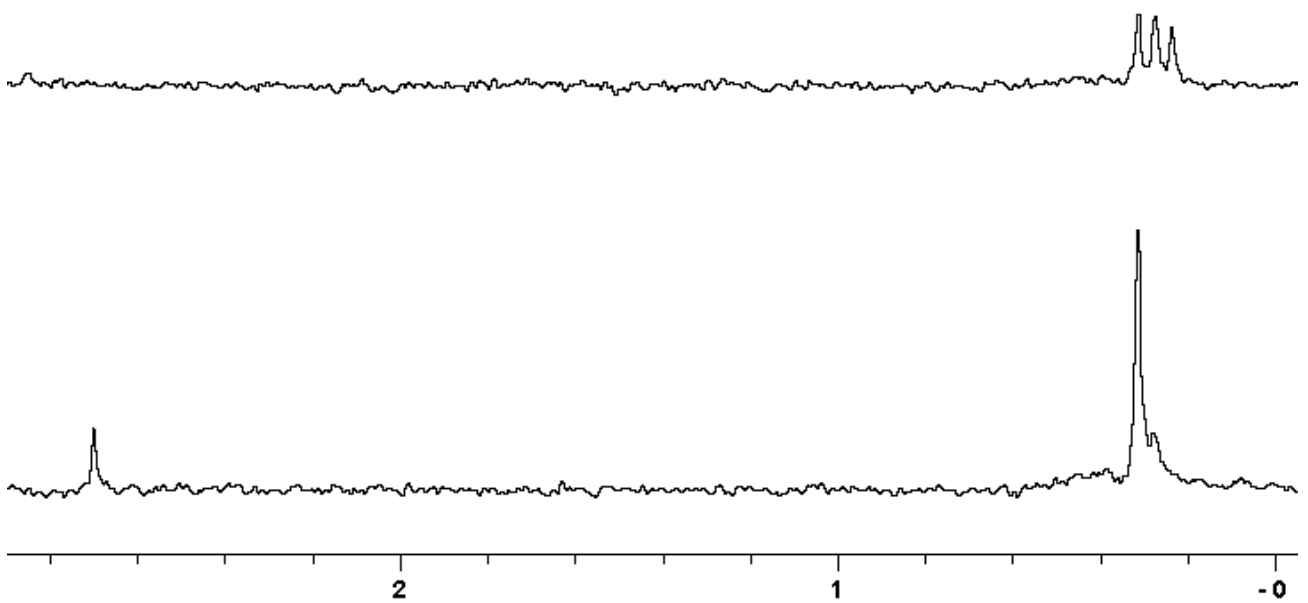

Figure S 31: Bottom: ${ }^{31} \mathrm{P}$ NMR $\left(202 \mathrm{Mhz}, 25^{\circ} \mathrm{C}\right)$ spectrum of 1 a after 10min in $\left.\mathrm{D}_{2} \mathrm{O}\right)$ showing partial hydrolysis, Top: after $16 \mathrm{~h}$ showing full hydrolysis and incorporation of deuterium. The Selenium and Sulphur derivate do not show hydrolysis in pure $\mathrm{D}_{2} \mathrm{O}$ 


\section{Crystallographic Details}

1c. $\mathrm{Et}_{3} \mathrm{NHCl}$ : One $\mathrm{CF}_{3}$ group is modelled as rotationally disordered with 3 sets of $\mathrm{F}$ atoms. All $\mathrm{C}---\mathrm{F}$ distances are restrained to a common refined value and all F...F distances are restrained to 1.633 times that value. All $F$ atoms are refined with isotropic ADPs and the site occupancies of the three groups are very tightly restrained to sum to 1.0 using a SUMP instruction. The other $\mathrm{CF}_{3}$ groups have tolerable displacement ellipsoids with just one set of $\mathrm{F}$ atom positions. The $\mathrm{H}$ atoms of the $\mathrm{NH}$ groups of the main residue are refined with isotropic ADPs and $\mathrm{N}-\mathrm{H}$ restrained to $0.90(1)$ angstrom. The $\mathrm{H}$ atom of the triethylammonium cation is placed geometrically and refined as riding. A molecule of diethylether is disordered across the inversion centre at $1 / 2,1 / 2,1 / 2$. It was difficult to produce any physically reasonable model for the molecule, so SQUEEZE was applied. SQUEEZE corrects for 42 electrons in this void, which corresponds exactly to $\mathrm{C}_{4} \mathrm{H}_{10} \mathrm{O}$.

A-1.Et ${ }_{3} \mathbf{N H C l}$ : Two of the four independent $\mathrm{CF}_{3}$ groups are modelled as two components. All C--- $\mathrm{F}$ distances are restrained to a common refined value and all F...F distances are restrained to 1.633 times that value. All F atoms are refined with anisotropic ADPs, restrained with an ISOR instruction. This approach provides a reasonable fit in each case, without seriously distorted ADPs. The other two $\mathrm{CF}_{3}$ groups are modelled as just one component with no special treatment. The $\mathrm{H}$ atoms of the $\mathrm{NH}$ groups of the main residue are refined with isotropic ADPs and $\mathrm{N}-\mathrm{H}$ restrained to $0.90(1)$ angstrom. The $\mathrm{H}$ atom of the triethylammonium cation is placed geometrically and refined as riding.

$1 \mathrm{c}(\mathrm{AuCl})_{2} . \mathrm{Et}_{3} \mathrm{NHCl}$ : Two of the four independent $\mathrm{CF}_{3}$ groups are modelled as two components. All C--F distances are restrained to a common refined value and all $F$...F distances are restrained to 1.633 times that value. All $\mathrm{F}$ atoms are refined with anisotropic ADPs, but the disordered atoms are restrained with a tight ISOR instruction. This approach provides a reasonable fit in each case, without seriously distorted ADPs. The other two $\mathrm{CF}_{3}$ groups are modelled as just one component with no special treatment. The $\mathrm{H}$ atoms of the $\mathrm{NH}$ groups (including the triethylammonium cation) are placed geometrically and refined as riding. They all form obvious hydrogen bonds to the chloride anion.

Table S1 Summary of Crystallographic Data

\begin{tabular}{|c|c|c|c|c|}
\hline Compound number & 1c. Et ${ }_{3} \mathrm{NHCl}$ & A-1. $\mathrm{Et}_{3} \mathrm{NHCl}$ & $1 \mathrm{c}(\mathrm{AuCl})_{2} \cdot \mathrm{Et}_{3} \mathrm{NHCl}$ & 2. $\mathrm{Et}_{3} \mathrm{NHCl}$ \\
\hline CCDC number & 1890522 & 1890516 & 1890517 & 1890521 \\
\hline Cambridge data number & DW_B1_0243 & DW_B1_0255 & DW_B1_0261 & DW_B1_0270 \\
\hline Chemical formula & $\mathrm{C}_{32} \mathrm{H}_{47} \mathrm{ClF}_{12} \mathrm{~N}_{5} \mathrm{O}_{0.5} \mathrm{P}_{2} \mathrm{Se}_{2}$ & $\mathrm{C}_{30} \mathrm{H}_{42} \mathrm{ClF}_{12} \mathrm{~N}_{5} \mathrm{P}_{2}$ & $\mathrm{C}_{30} \mathrm{H}_{42} \mathrm{Au}_{2} \mathrm{Cl}_{3} \mathrm{~F}_{12} \mathrm{~N}_{5} \mathrm{P}_{2}$ & $\mathrm{C}_{38} \mathrm{H}_{30} \mathrm{ClF}_{24} \mathrm{~N}_{5} \mathrm{P}_{2}$ \\
\hline Formula weight & 993.05 & 798.07 & 1262.91 & 1110.06 \\
\hline Temp/K & $180(2)$ & $180(2)$ & $180(2)$ & $180(2)$ \\
\hline Crystal system & triclinic & triclinic & monoclinic & triclinic \\
\hline Space group & $P-1$ & $P-1$ & $P 21 / n$ & $P-1$ \\
\hline 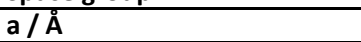 & $12.5792(4)$ & $8.5938(3)$ & $13.9922(4)$ & $12.4964(4)$ \\
\hline b/A & $12.9314(4)$ & $12.6025(5)$ & $14.1100(4)$ & $13.1178(4)$ \\
\hline c/ $\AA$ & $15.3966(5)$ & $18.7895(7)$ & $21.4076(6)$ & $15.3713(5)$ \\
\hline$\alpha /^{\circ}$ & $102.5965(14)$ & $90.270(2)$ & 90 & $87.935(2)$ \\
\hline$\beta /^{\circ}$ & $96.241(2)$ & $98.808(2)$ & $93.5574(14)$ & $82.314(2)$ \\
\hline$\gamma /^{\circ}$ & $113.5051(13)$ & $103.186(2)$ & 90 & $67.010(2)$ \\
\hline Unit-cell volume $/ \AA^{3}$ & $2187.19(12)$ & $1956.29(13)$ & $4218.4(2)$ & $2298.41(13)$ \\
\hline $\bar{Z}$ & 2 & 2 & 4 & 2 \\
\hline Calc. density $/ \mathrm{g} \mathrm{cm}^{-3}$ & 1.508 & 1.355 & 1.989 & 1.604 \\
\hline$F(000)$ & 1002 & 824 & 2416 & 1112 \\
\hline Radiation type & CuK $\alpha$ & CuK $\alpha$ & CuK $\alpha$ & CuK $\alpha$ \\
\hline Absorption coefficient $/ \mathrm{mm}^{-1}$ & 4.106 & 2.409 & 16.105 & 2.633 \\
\hline
\end{tabular}




\begin{tabular}{|c|c|c|c|c|}
\hline Crystal size $/ \mathrm{mm}^{3}$ & $0.20 \times 0.20 \times 0.07$ & $0.35 \times 0.15 \times 0.15$ & $0.10 \times 0.03 \times 0.02$ & $0.36 \times 0.24 \times 0.05$ \\
\hline 2-Theta range $/^{\circ}$ & $6.03-133.89$ & $4.76-133.40$ & $7.34-133.38$ & $5.80-133.31$ \\
\hline Completeness to max 2-theta & 0.989 & 0.992 & 0.998 & 0.992 \\
\hline No. reflections measured & 21496 & 22203 & 33340 & 26994 \\
\hline No. independent reflections & 7707 & 6854 & 7459 & 8070 \\
\hline $\mathbf{R}_{\text {int }}$ & 0.0435 & 0.0542 & 0.0543 & 0.0547 \\
\hline No. parameters / restraints & $499 / 21$ & $525 / 134$ & $553 / 96$ & $792 / 350$ \\
\hline Final $R 1$ values $(I>2 \sigma(I))$ & 0.0431 & 0.0524 & 0.0296 & 0.0632 \\
\hline Final $w R\left(\mathrm{~F}^{2}\right)$ values (all data) & 0.0598 & 0.0752 & 0.0459 & 0.0792 \\
\hline Goodness-of-fit on $\mathrm{F}^{2}$ & 1.019 & 1.038 & 1.013 & 1.037 \\
\hline Largest difference peak \& hole / e $\AA^{3}$ & $0.655,-0.555$ & $0.601,-0.309$ & $0.985,-0.659$ & $0.919,-0.653$ \\
\hline
\end{tabular}

Single-crystal XRD data were processed and refined with SHELX:

[1] Sheldrick, G. M. Acta Crystallogr. 2015, 71C, 3-8.

[2] Sheldrick, G. M. Acta Crystallogr. 2015, 71A, 3-8.

Single Crystal XRD data was processed and refined with SHELX, see:

[1] Sheldrick, G. M. Acta Crystallogr. 2015, 71C, 3-8.

[2] Sheldrick, G. M. Acta Crystallogr. 2015, 71A, 3-8.

\section{Computational Details}

All calculations were performed using the Turbomole V7.0.1 program package. ${ }^{[1]}$ Structure optimizations at DFT level have been performed by the B3LYP hybrid functional with the triple $-\zeta$ basis set def2-TZVPD at an $\mathrm{m} 5$ grid. ${ }^{[2-4]}$ Dispersion correction by Grimme (D3) and Becke-Johnson (BJ) damping was employed for the calculations as implemented. ${ }^{[5,6]}$ Minimum structures have been confirmed by frequency analysis within the harmonic approximation as implemented in the Turbomole code. For visualization the program VMD V1.9.7 was used. ${ }^{[7]}$

\section{Results}

We have optimized the structures of $\mathbf{3 a}, \mathbf{3} \mathbf{b}$ and $\mathbf{3} \mathbf{c}$ at DFT level of theory (B3LYP) and analyzed the electron density to gain a deeper understanding for the experimental results. An AIM analysis was performed based on the optimized structures. ${ }^{[8]}$ As anticipated we found bond critical points (BCPs) between the exo-N atom and the acidic proton for all three derivatives. The electron density at the $B C P$ s varies depending on the chalcogen $(\mathrm{O}, \mathrm{S}, \mathrm{Se})$ attached to the $\mathrm{P}_{2} \mathrm{~N}_{2}$ backbone of the molecule. Calculations suggest decreasing electron density at these BCPs following the atomic numbers of the chalcogens, i.e. the oxygen derivative shows the highest electron density with $\rho=0.3406 \mathrm{e} / \AA^{3}$, followed by the sulphur containing molecule with $\rho=0.3393 \mathrm{e} / \AA^{3}$ whereas the selenium homologue shows an electron density of $\rho=0.3387 \mathrm{e} / \AA^{3}$ at the BCP. This suggests that the $\mathrm{N}-\mathrm{H}$ bond is strongest for the oxygen containing molecule and is getting weaker for the heavier homologues. This is in line with experimental results, showing that the double deprotonation of the Se and $\mathrm{S}$ derivatives is possible at ambient temperature, whereas elevated temperatures are necessary for the $\mathrm{O}$ derivative.

Based on the optimized structures we have calculated the LUMOs of $\mathbf{3 a}, \mathbf{3 b}$ and $\mathbf{3} \mathbf{c}$. The main contribution is the $\sigma^{*}$ orbital of the $\mathrm{N}-\mathrm{H}$ bond. At the same time this is the receptor site for anion 
binding. The energies of the LUMOs are all negative suggesting an energy gain upon occupation. The LUMO energy of the Se derivative is most negative with $E_{\text {LUMO }}^{\text {Se }}=-0.629 \mathrm{eV}$ followed by the $\mathrm{S}$ analogue with $E_{\text {LUMO }}^{\mathrm{S}}=-0.571 \mathrm{eV}$ and the $\mathrm{O}$ homologue has an even higher energy with $\mathrm{E}_{\text {LUMO }}^{\mathrm{O}}=-$ $0.517 \mathrm{eV}$. This rationalizes the experimental finding of different anion binding strengths between $\mathbf{3 a}$, $\mathbf{3 b}$ and $\mathbf{3 c}$. The latter yields the strongest receptor-anion complex due to the highest energy release. The sulphur oxidized derivative forms under similar conditions weaker bound complexes due to the higher energy LUMO. The oxygen homologue has the highest LUMO in this series and therefore forms the weakest anion complexes. The lowering of the LUMO energies can be understood considering the chemical hardness of the chalcogens. The harness is connected to the HOMO LUMO gap, whereas a large HOMO-LUMO gap indicates a hard moiety. ${ }^{[9]}$ Figure 9 (lower panel) of the paper shows the corresponding $\mathrm{HOMO}$ and LUMO energies of the $\mathrm{O}, \mathrm{S}$ and Se analogues, indicating the selenium containing derivative is the softest due to the small HOMO LUMO gap ( $5.07 \mathrm{eV})$ in comparison to the sulphur $(5.33 \mathrm{eV})$ and the oxygen derivative $(5.72 \mathrm{eV})$. This is also visible in the electrostatic potentials (Figure 9, upper panel) which show a significant negative charge accumulation at the oxygen atoms. Going to the heavier homologues the ESP are more homogenous without significant charge on the chalcogens suggesting a better delocalization and polarisability. A similar trend is observed for the natural charges (Figure S32). Here, the oxygen is calculated to carry a negative charge of -1.085 in contrast to Sulphur $(-0.576)$ and selenium which shows the lowest with -0.489 .

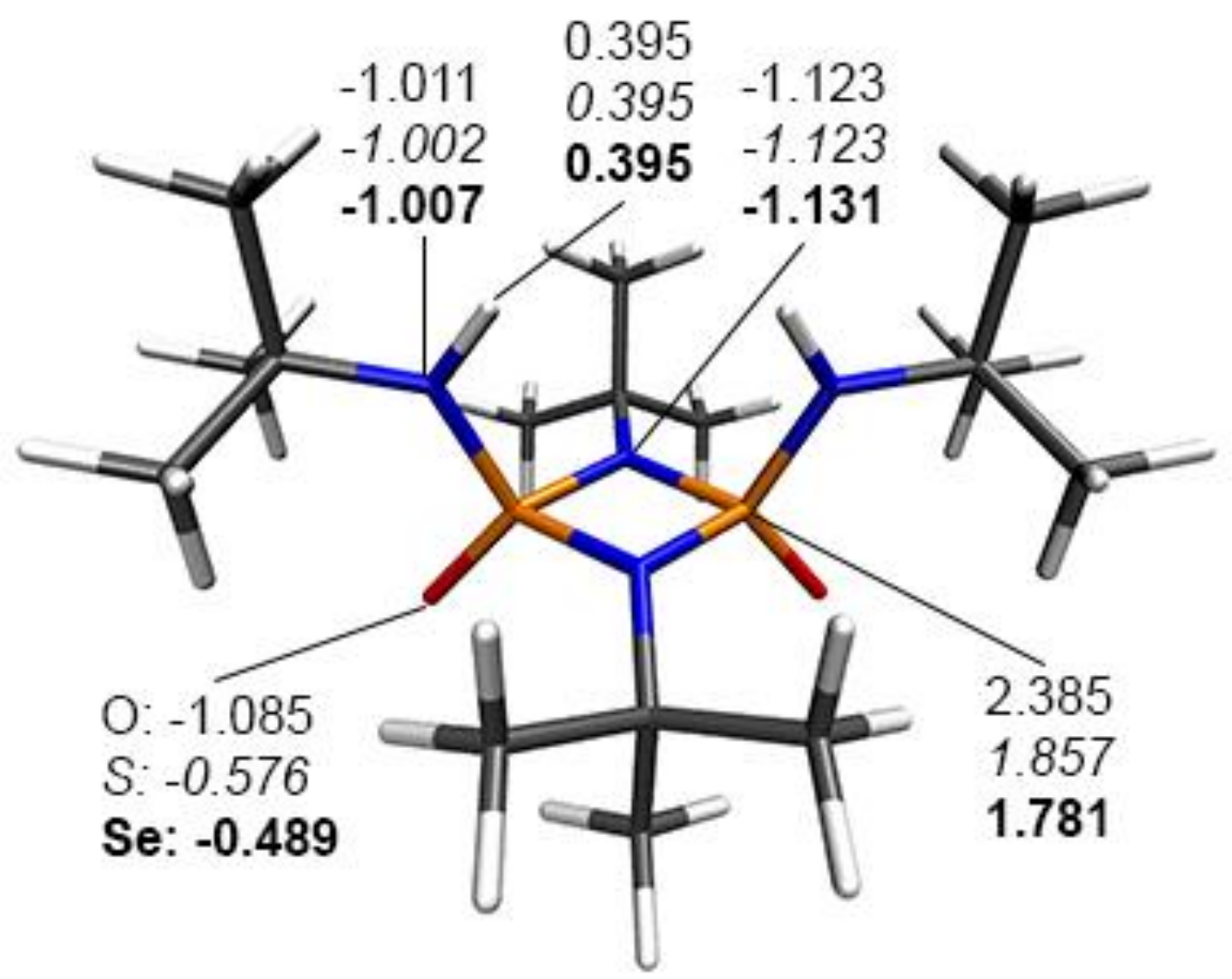

Figure S 32 NPAs of $3 a$ (regular), $3 b$ (italic) and 3c (bold), calculated on B3LYP-D3-BJ/def2-TZVPD. 
TURBOMOLE GmbH, TURBOMOLE V7.0.1, A development of University of Karlsruhe and Forschungszentrum Karlsruhe $\mathrm{GmbH}$, http://turbomole.com/, 1989-2015.

[2] Becke, A. D. J. Chem. Phys. 1993, 98, 1372.

[3] Lee, C.; Yang, W.; Parr, R. G. Phys. Rev. B 1988, 37, 785.

[4] Rappoport, D.; Furche, F. J. Chem. Phys. 2010, 133, 134105.

[5] Grimme, S.; Antony, J.; Ehrlich, S.; Krieg, H. J. Chem. Phys. 2010, 132, 154104.

[6] Grimme, S.; Ehrlich, S.; Goerigk, L. J. Comp. Chem. 2011, 32, 1456.

[7] Humphrey, W., Dalke, A.; Schulten, K. J. Molec. Graphics 1996, 14, 33.

[8] Bader, R. F. W. Encyclopedia of Computational Chem, Vol 1, ed. P. v. Schleyer, John Wiley and Sons, Chichester, 1998, 64-86.

[9] Parr, R. G.; Pearson, R.G. J. Am. Chem. Soc. 1983, 105, 7512.

\section{Appendix}

Optimized atomic coordinates of $\mathbf{2 a}$ in $x y z$ format:

$\begin{array}{cccc}\text { P } & 0.1423823 & 0.8699892 & -1.1790554 \\ \text { P } & 1.1231335 & -0.0324401 & 0.9511303 \\ \text { N } & 1.0920273 & -0.4493266 & -0.6932168 \\ \text { N } & 0.1208411 & 1.2339541 & 0.4672808 \\ \text { N } & -1.3675150 & 0.3646560 & -1.6206803 \\ H & -1.7745437 & -0.3559463 & -1.0462912 \\ \text { N } & 0.2227407 & -1.0975952 & 1.8369568 \\ H & -0.6460791 & -1.3908892 & 1.4198202 \\ \text { O } & 0.6803623 & 1.8249379 & -2.1608614 \\ \text { O } & 2.4153819 & 0.2278933 & 1.6050270 \\ \text { C } & 2.1563505 & -1.1324575 & -1.4731192 \\ \text { C } & 1.5812412 & -1.4996408 & -2.8405204 \\ H & 0.6976544 & -2.1311874 & -2.7336987 \\ H & 2.3285566 & -2.0440580 & -3.4196951 \\ H & 1.3078514 & -0.6059420 & -3.4000003 \\ \text { C } & 3.3692245 & -0.2087428 & -1.6382334 \\ H & 3.7713833 & 0.0645457 & -0.6627901 \\ H & 3.0815922 & 0.7023822 & -2.1627271 \\ \text { H } & 4.1497608 & -0.7135092 & -2.2119327 \\ \text { C } & 2.5562653 & -2.4010454 & -0.7207661 \\ H & 1.6931946 & -3.0517700 & -0.5701225 \\ H & 2.9859974 & -2.1581790 & 0.2501791 \\ \text { H } & 3.3067344 & -2.9476159 & -1.2938793 \\ \text { C } & -0.6354317 & 2.2378855 & 1.2419405 \\ \text { C } & -0.8036469 & 3.4898614 & 0.3783752 \\ H & -1.3866679 & 3.2810245 & -0.5175862\end{array}$




$\begin{array}{lrrr}\text { H } & 0.1668589 & 3.8751135 & 0.0669706 \\ H & -1.3243813 & 4.2602376 & 0.9491076 \\ \mathrm{C} & -2.0068501 & 1.6746422 & 1.6340446 \\ \mathrm{H} & -1.8910394 & 0.7805027 & 2.2478070 \\ \mathrm{H} & -2.5825612 & 1.4173326 & 0.7441067 \\ \mathrm{H} & -2.5730218 & 2.4116550 & 2.2068026 \\ \mathrm{C} & 0.1701521 & 2.5905938 & 2.4942318 \\ \mathrm{H} & 0.2967007 & 1.7256914 & 3.1439561 \\ \mathrm{H} & -0.3525504 & 3.3642040 & 3.0587499 \\ \mathrm{H} & 1.1600134 & 2.9572707 & 2.2241017 \\ \mathrm{C} & -2.1495239 & 0.6874137 & -2.8421478 \\ \mathrm{C} & -3.4511246 & -0.1090190 & -2.7283316 \\ \mathrm{H} & -4.0034466 & 0.1739883 & -1.8290381 \\ \mathrm{H} & -3.2486876 & -1.1825412 & -2.6926150 \\ \mathrm{H} & -4.0883386 & 0.0839618 & -3.5918227 \\ \mathrm{C} & -2.4630190 & 2.1854242 & -2.8915910 \\ \mathrm{H} & -3.0355571 & 2.4862904 & -2.0124267 \\ \mathrm{H} & -3.0546118 & 2.4158812 & -3.7797228 \\ \mathrm{H} & -1.5414618 & 2.7642930 & -2.9299085 \\ \mathrm{C} & -1.3989909 & 0.2713191 & -4.1105341 \\ \mathrm{H} & -1.1753681 & -0.7961478 & -4.0932685 \\ \mathrm{H} & -0.4657573 & 0.8251896 & -4.1976439 \\ \mathrm{H} & -2.0091433 & 0.4808135 & -4.9913017 \\ \mathrm{C} & 0.5802825 & -1.8262399 & 3.0814227 \\ \mathrm{C} & -0.6246818 & -2.7103846 & 3.4092003 \\ \mathrm{H} & -0.8133360 & -3.4249883 & 2.6039294 \\ \mathrm{H} & -1.5222888 & -2.1056155 & 3.5590603 \\ \mathrm{H} & -0.4407109 & -3.2753639 & 4.3234509 \\ \mathrm{C} & 0.8217664 & -0.8372454 & 4.2252855 \\ \mathrm{H} & 1.6507615 & -0.1736125 & 3.9840361 \\ \mathrm{H} & 1.0649598 & -1.3767946 & 5.1427478 \\ \mathrm{H} & -0.0717788 & -0.2377846 & 4.4084880 \\ \mathrm{C} & 1.8215669 & -2.6998487 & 2.8785401 \\ \mathrm{H} & 2.6843047 & -2.0820263 & 2.6350679 \\ \mathrm{H} & 1.6612479 & -3.4156701 & 2.0712591 \\ \mathrm{H} & 2.0408251 & -3.2553204 & 3.7924519\end{array}$

Optimized atomic coordinates of $\mathbf{2} \mathbf{b}$ in xyz format:
C $0.1727818 \quad-2.7655310 \quad-2.5918931$
C $0.1584141-2.5628361 \quad-1.0718501$
C $1.4446408-3.1195910-0.4604283$
$\begin{array}{llll}\text { N } & 0.0673734 & -1.1199223 & -0.7388172\end{array}$
$\begin{array}{llll}\text { P } & 1.2655827 & 0.0811454 & -0.8058359\end{array}$
S $\quad 2.4676535 \quad 0.2064163 \quad-2.3136472$
$\begin{array}{llll}\text { C } & -1.0481643 & -3.2739980 & -0.4591187\end{array}$
$\begin{array}{llll}\text { P } & -1.2660635 & -0.0628277 & -0.8075068\end{array}$

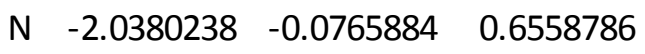
$\begin{array}{llll}\text { C } & -3.4622282 & -0.1968657 & 1.0733315\end{array}$
$\begin{array}{llll}C & -3.4358935 & -0.1880376 & 2.6046507\end{array}$
$\begin{array}{llll}\text { N } & -0.0679173 & 1.1364908 & -0.7103319\end{array}$ 


\begin{tabular}{|c|c|c|c|}
\hline C & 6948 & 3817 & 1968 \\
\hline & -1.4444661 & 3.1296483 & -0.3846658 \\
\hline & -2.4681526 & -0.1544307 & -2.3177133 \\
\hline & 1.0485532 & 3.2829285 & -0.3809105 \\
\hline & -0.1736250 & 2.8252468 & -2.5243587 \\
\hline & 2.0378616 & 0.0633544 & 0.6571831 \\
\hline & 3.4624120 & 0.1716330 & 1.0770572 \\
\hline & 3.4362228 & 0.1290369 & 2.6078036 \\
\hline & 4.0781141 & 1.4971693 & 0.6226705 \\
\hline$c$ & 4.2894556 & -1.0061961 & 0.5520037 \\
\hline C & -4.2918906 & 0.9904811 & 0.5743059 \\
\hline C & -4.0749820 & -1.5134121 & 0.5900009 \\
\hline H & -0.7350432 & -2.3636473 & -3.0392913 \\
\hline 1 & 0.2365011 & -3.8312855 & -2.8223315 \\
\hline 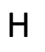 & 1.0284431 & -2.2590865 & -3.0366251 \\
\hline $\mathrm{H}$ & -1.0844858 & -3.1198708 & 0.6202505 \\
\hline H & -0.9774278 & -4.3448054 & -0.6559751 \\
\hline $\mathrm{H}$ & -1.9782926 & -2.9124743 & -0.8952134 \\
\hline $\mathrm{H}$ & 2.3233126 & -2.6394922 & -0.8890819 \\
\hline 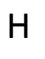 & 1.5098003 & -4.1887156 & -0.6679830 \\
\hline 7 & 1.4596611 & -2.9749519 & 0.6208305 \\
\hline I & 4.2936763 & -1.0188612 & -0.5362224 \\
\hline$H$ & 3.8829709 & -1.9520175 & 0.9118875 \\
\hline 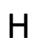 & 5.3203027 & -0.9205074 & 0.9013236 \\
\hline 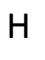 & 4.4501025 & 0.2017362 & 3.0021247 \\
\hline H & 3.0039036 & -0.8092942 & 2.9652595 \\
\hline H & -4.0756112 & -1.5660788 & -0.4968030 \\
\hline $\mathrm{H}$ & -5.1066842 & -1.5867889 & 0.9391066 \\
\hline $\mathrm{H}$ & -3.5178009 & -2.3639757 & 0.9830169 \\
\hline $\mathrm{H}$ & -4.4495868 & -0.2709173 & 2.9974557 \\
\hline$H$ & 1.4153568 & -0.1538111 & 1.4214398 \\
\hline $\mathrm{H}$ & -1.4175820 & 0.1366051 & 1.4229083 \\
\hline $\mathrm{H}$ & -1.0297626 & 2.3299157 & -2.9805539 \\
\hline $\mathrm{H}$ & -0.2368873 & 3.8961627 & -2.7296123 \\
\hline $\mathrm{H}$ & 0.7337766 & 2.4335748 & -2.9815697 \\
\hline $\mathrm{H}$ & -1.4589480 & 2.9604698 & 0.6930528 \\
\hline $\mathrm{H}$ & -1.5095070 & 4.2032616 & -0.5676214 \\
\hline $\mathrm{H}$ & -2.3235102 & 2.6597068 & -0.8237041 \\
\hline $\mathrm{H}$ & 1.9783101 & 2.9311380 & -0.8257086 \\
\hline $\mathrm{H}$ & 0.9783012 & 4.3580733 & -0.5527256 \\
\hline $\mathrm{H}$ & 1.0853175 & 3.1037385 & 0.6945883 \\
\hline $\mathrm{H}$ & 4.0782221 & 1.5737636 & -0.4627177 \\
\hline $\mathrm{H}$ & 3.5231727 & 2.3402154 & 1.0346965 \\
\hline $\mathrm{H}$ & 5.1101753 & 1.5604410 & 0.9726971 \\
\hline $\mathrm{H}$ & 2.8541124 & 0.9612037 & 3.0104066 \\
\hline $\mathrm{H}$ & -4.2962410 & 1.0268714 & -0.5133890 \\
\hline 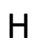 & -5.3225155 & 0.8952436 & 0.9218284 \\
\hline . & -3.8872328 & 1.9290911 & 0.9546387 \\
\hline I & -3.0050889 & 0.7429482 & 2.9826616 \\
\hline & 2.8521 & -1.0277 & 2.9886 \\
\hline
\end{tabular}


Optimized atomic coordinates of $\mathbf{2 c}$ in xyz format:
C $\quad 0.0202649-2.6421610-2.7781575$
C $0.0160905-2.5045977-1.2512228$
$\begin{array}{llll}N & 0.0033135 & -1.0732225 & -0.8552561\end{array}$
P $\quad-1.2704304 \quad 0.0606383-0.8426345$
$\begin{array}{llll}\text { N } & -0.0037881 & 1.1828639 & -0.6970714\end{array}$
C $-0.0166415 \quad 2.6552698-0.8915579$
C $1.2257982 \quad 3.2383311-0.2182729$
C $\quad-1.2268235 \quad-3.1750806 \quad-0.6658939$
$\begin{array}{lrrr}C & 1.2699850 & -3.1578309 & -0.6676829\end{array}$
$\begin{array}{llll}\text { P } & 1.2699671 & 0.0581046 & -0.8430232\end{array}$
$\begin{array}{llll}N & 2.0131936 & -0.1137466 & 0.6260653\end{array}$
$\begin{array}{llll}\text { C } & 3.4258895 & -0.0963057 & 1.0994148\end{array}$
C $4.1133187 \quad 1.2269805 \quad 0.7577450$
C $4.2197337-1.2747954 \quad 0.5266656$
$\begin{array}{llll}\text { C } & 3.3381283 & -0.2370977 & 2.6221417\end{array}$
Se $2.5911737 \quad 0.2255137 \quad-2.4569597$
Se $-2.5922193 \quad 0.1189504 \quad-2.4637489$
$\begin{array}{llll}N & -2.0130285 & 0.0269587 & 0.6364017\end{array}$
C $-3.4253152 \quad-0.0583341 \quad 1.1034479$
C $-4.2208388 \quad 1.1876331 \quad 0.7011694$
C $\quad-4.1115122 \quad-1.3218523 \quad 0.5809520$
$\begin{array}{llll}\text { C } & -3.3365945 & -0.1313870 & 2.6308532\end{array}$
$\begin{array}{llll}\text { C } & -0.0199136 & 3.0027730 & -2.3847889\end{array}$
C $-1.2711322 \quad 3.2213430-0.2242432$
H $\quad-0.8643579 \quad-2.1742617 \quad-3.2071370$
H $\quad 0.0274203 \quad-3.6991127 \quad-3.0532107$
H $\quad 0.9019915-2.1639004 \quad-3.2025479$
H $\quad-1.2506994 \quad-3.07223120 .4199316$
H $\quad-1.2160299 \quad-4.2373581 \quad-0.9144940$
H $\quad-2.1367050 \quad-2.7421094 \quad-1.0792739$
H $\quad 2.1747750 \quad-2.7064835 \quad-1.0729769$
H $\quad 1.2766177 \quad-4.2173575 \quad-0.9279655$
H $\quad 1.2906317 \quad-3.06916830 .4195170$
H $\quad 4.2665903 \quad-1.2170474 \quad-0.5592313$
H $3.7575204 \quad-2.2219903 \quad 0.8071870$
H $\quad 5.2386817 \quad-1.2607903 \quad 0.9183816$
H $4.3382169-0.2404231 \quad 3.0562749$
H $2.8495241 \quad-1.1749297 \quad 2.9000655$
$\begin{array}{llll}H & -4.1625803 & -1.3178250 & -0.5059537\end{array}$
H $\quad-5.1291654-1.3714647 \quad 0.9725295$
H $-3.5745415-2.2134599 \quad 0.9048291$
$\begin{array}{llll}H & -4.3362889 & -0.1914999 & 3.0617054\end{array}$
H $1.3654904 \quad-0.4115200 \quad 1.3416214$
$\begin{array}{llll}H & -1.3654002 & 0.2250372 & 1.3857532\end{array}$
$\begin{array}{llll}H & -0.9008432 & 2.5869649 & -2.8720417\end{array}$
$\begin{array}{llll}\mathrm{H} & -0.0282374 & 4.0876165 & -2.5108896\end{array}$
H $\quad 0.8654695 \quad 2.5998402-2.8739175$
$\begin{array}{llll}H & -1.2923826 & 2.9835414 & 0.8403064\end{array}$
H $-1.2780822 \quad 4.3066220 \quad-0.3359496$
H $\quad-2.1754841 \quad 2.8298802 \quad-0.6885884$ 


$\begin{array}{rrrr}H & 2.1360345 & 2.8664569 & -0.6867677 \\ H & 1.2152229 & 4.3247651 & -0.3177892 \\ H & 1.2488174 & 2.9864132 & 0.8429548 \\ H & 4.1643843 & 1.3740344 & -0.3191766 \\ H & 3.5770858 & 2.0653761 & 1.2024445 \\ H & 5.1310328 & 1.2207035 & 1.1522645 \\ H & 2.7793482 & 0.5939308 & 3.0582808 \\ H & -4.2695678 & 1.2810355 & -0.3821505 \\ H & -5.2390947 & 1.1187168 & 1.0889170 \\ H & -3.7585637 & 2.0871003 & 1.1095317 \\ H & -2.8502093 & 0.7596324 & 3.0370164 \\ H & -2.7752408 & -1.0136826 & 2.9462065\end{array}$

AIM analysis of 2a:

\begin{tabular}{|c|c|c|c|c|c|c|c|c|c|c|}
\hline Point & $x$ & $Y$ & Z & ty & Lap & $\operatorname{ian} G(r) / D(r$ & r) $K(r) / D(r)$ & $\mathrm{EV}(1)$ & $\mathrm{EV}(2)$ & \\
\hline$P$ & 1 & 0.269 & 1.644 & & & 07 & 00 & -03 & +07 & - \\
\hline$P$ & 2 & 2.122 & -0.061 & 1.7972 & $3 \mathrm{E}+03$ & & $3.069 \mathrm{E}+00$ & $9.717 E+03$ & $-2.724 \mathrm{E}+07-2.724 \mathrm{E}+07$ & $-2.724 \mathrm{E}+07$ \\
\hline $\mathrm{N}$ & 3 & 2.064 & -0.849 & -1.310 & & $212 E+06$ & & & $75 E+05-7.375 E+05$ & $-7.374 \mathrm{E}+05$ \\
\hline $\mathrm{N}$ & 4 & 0.228 & 2.332 & 0.8831 & $1.981 \mathrm{E}+02$ & $12 \mathrm{E}+06$ & 1.477 & & $\mathrm{E}+05$ & $73 \mathrm{E}+05$ \\
\hline $\mathrm{N}$ & 5 & -2.584 & 0.689 & -3.063 & $1.980 \mathrm{E}+02$ & $-2.210 \mathrm{E}+06$ & $1.48 \mathrm{~s}$ & & $3 E+05-7$ & $7 \mathrm{E}+05$ \\
\hline $\mathrm{H}$ & 6 & -3.339 & -0.647 & & -01 & $5 \mathrm{E}+01$ & 4.16 & $E+01$ & $+00-8.873 E+00$ & $1 \mathrm{E}+00$ \\
\hline $\mathrm{N}$ & 7 & 0.421 & -2.074 & 711 & $1.980 \mathrm{E}+02$ & $-2.210 \mathrm{E}+06$ & 1.4 & +03 & $68 \mathrm{E}+05-7.368 \mathrm{E}+05$ & $7 \mathrm{E}+05$ \\
\hline $\mathrm{H}$ & 8 & -1.190 & -2.618 & & & & 4.1 & & $E+00-8$. & $\mathrm{E}+00$ \\
\hline 0 & 9 & 1.286 & 3.449 & 833 & $E+02$ & $-4.509 E+06$ & 2.5 & +03 & $06-1$ & $=06$ \\
\hline $\mathrm{O}$ & 10 & 4.564 & & & & $-4.509 E+06$ & & & +06 & $E+06$ \\
\hline C & 11 & 4.075 & -2.140 & & & & & & $3 E+05-3$ & $3 \mathrm{E}+05$ \\
\hline C & 12 & 2.988 & -2.834 & -5.368 & $1.219 \mathrm{E}+02$ & $-9.671 E+05$ & 7.46 & 1.98 & $3-3.224 E+05-3.224 E+05$ & $4 \mathrm{E}+05$ \\
\hline $\mathrm{H}$ & 13 & 1.340 & -4.012 & 68 & $4.4 €$ & $-2.698 \mathrm{E}+01$ & 1.6 & 1. & $00-9$. & $\mathrm{E}+00$ \\
\hline H & 14 & 382 & -3. & & 1 & & & & 00 & $9 \mathrm{E}+00$ \\
\hline H & 15 & 2.478 & -1.167 & & $\mathrm{E}-01$ & $E+01$ & & & $E+00-9.1$ & $-8.490 E+00$ \\
\hline C & 16 & 6.367 & -0.394 & 96 & $1.219 \mathrm{E}+02$ & & & & $05-3$. & $4 \mathrm{E}+05$ \\
\hline $\mathrm{H}$ & 17 & 7.117 & 15 & -1.277 & 4.4 & $-2.671 E+01$ & 1.6 & & $00-9$ & $E+00$ \\
\hline H & 18 & 5.830 & 04 & & 4.43 & $-2.671 E+01$ & & & $=00-9$ & $1 E+00$ \\
\hline $\mathrm{H}$ & 19 & 7.823 & & & & & & & $=00-9$. & $E+00$ \\
\hline C & 20 & 4.831 & 37 & & 1.21 & & & & $05-3$ & $E+05$ \\
\hline $\mathrm{H}$ & 21 & 3.220 & 51 & -1.081 & 4.467E-01 & $-2.698 E+01$ & 1.6 & 1. & $E+00-9$ & $E+00$ \\
\hline H & 22 & 32 & 34 & & 4.45 & & & & $-00-9$ & $E+00$ \\
\hline $\mathrm{H}$ & 23 & 31 & 57 & 31 & 4.4 & 01 & & & $-00-9$ & $E+00$ \\
\hline C & 24 & -1.201 & & 2.347 & 1.215 & $-9.669 \mathrm{E}+05$ & & & $+05-3$. & $E+05$ \\
\hline C & 25 & & & & 1.21 & & & & $+05-3$. & $E+05$ \\
\hline H & 26 & -2.606 & & & $E-01$ & $-2.698 \mathrm{E}+01$ & & & $E+00-9$ & $E+00$ \\
\hline $\mathrm{H}$ & 27 & 0.291 & 13 & 0.135 & 10 & $E+01$ & & & $E+00$ & $E+00$ \\
\hline H & 28 & -2.490 & & & & $-2.695 \mathrm{E}+01$ & & & $+00-9$. & $E+00$ \\
\hline C & 29 & -3.792 & 3.165 & 3.088 & $1.219 \mathrm{E}+02$ & $-9.672 E+05$ & 7.461 & $1.983 \mathrm{E}+03$ & $-3.224 \mathrm{E}+05-3.224 \mathrm{E}+05$ & $-3.224 \mathrm{E}+05$ \\
\hline $\mathrm{H}$ & 30 & & & & $4.466 \mathrm{E}-01$ & $-2.695 E+01$ & & & $-9.214 E+00-9.212 E+00$ & $6 \mathrm{E}+00$ \\
\hline $\mathrm{H}$ & 31 & -4.866 & 85 & 1.428 & $4.466 \mathrm{E}-01$ & +01 & 1.6 & +01 & $-9.213 E+00-9.2$ & $E+00$ \\
\hline $\mathrm{H}$ & 32 & -4.848 & 4.540 & 4.156 & $4.456 \mathrm{E}-01$ & $-2.692 \mathrm{E}+01$ & $1.662 \mathrm{E}-02$ & $1.511 \mathrm{E}+01$ & $-9.203 E+00-9.201 E+00$ & $-8.519 E+00$ \\
\hline C & 33 & 0.322 & 4.896 & 4.713 & $1.219 \mathrm{E}+02$ & $-9.671 E+05$ & $7.473 \mathrm{E}-02$ & $1.983 E+03$ & $-3.224 \mathrm{E}+05-3.224 \mathrm{E}+05$ & $-3.224 \mathrm{E}+05$ \\
\hline $\mathrm{H}$ & 34 & & & & 4.47 & $-2.698 \mathrm{E}+01$ & & +01 & $-9.225 E+00-9.223 E+00$ & $-8.529 E+00$ \\
\hline H & 35 & -0.654 & 39 & 5.766 & 4.46 & $-2.695 \mathrm{E}+01$ & 1.6 & +01 & $-9.213 E+00-9.212 E+00$ & $-8.529 E+00$ \\
\hline H & 36 & 2.167 & 80 & 4.209 & $4.441 \mathrm{E}-01$ & $-2.678 \mathrm{E}+01$ & 1.61 & $1.508 \mathrm{E}+01$ & $-9.163 E+00-9.161 E+00$ & $-8.458 \mathrm{E}+00$ \\
\hline C & 37 & -4.062 & 299 & -5.371 & $1.219 \mathrm{E}+02$ & $-9.669 E+05$ & $7.080 \mathrm{E}-02$ & $1.983 E+03$ & $3-3.223 E+05-3.223 E+05$ & $-3.223 E+05$ \\
\hline C & 38 & -6.522 & -0.206 & -5.156 & $1.219 \mathrm{E}+02$ & $-9.672 E+05$ & $7.452 \mathrm{E}-02$ & $1.983 \mathrm{E}+$ & $3-3.224 E+05-3.224 E+05$ & $-3.224 E+05$ \\
\hline H & 39 & -7.552 & 0.322 & -3.478 & 4.457E-01 & $-2.694 \mathrm{E}+01$ & $1.654 \mathrm{E}-02$ & $1.511 \mathrm{E}+01$ & $1-9.207 E+00-9.204 E+00$ & $-8.525 E+00$ \\
\hline H & 40 & -6.144 & -2.209 & -5.089 & 4.457E-01 & $-2.694 \mathrm{E}+01$ & $1.658 \mathrm{E}-02$ & $1.511 \mathrm{E}+01$ & $1-9.208 E+00-9.205 E+00$ & $-8.529 E+00$ \\
\hline $\mathrm{H}$ & 41 & -7.710 & 0.154 & -6.767 & $4.452 \mathrm{E}-01$ & $-2.689 E+01$ & $1.635 \mathrm{E}-02$ & $1.510 \mathrm{E}+01$ & $1-9.194 E+00-9.192 E+00$ & $-8.500 E+00$ \\
\hline C & 42 & -4.654 & 4.130 & -5.464 & $1.219 E+02$ & $-9.671 E+05$ & $7.468 \mathrm{E}-02$ & $1.983 E+03$ & $3-3.224 E+05-3.224 E+05$ & $-3.224 \mathrm{E}+05$ \\
\hline
\end{tabular}


$\begin{array}{cccc}\mathrm{H} & 43 & -5.723 & 4.691 \\ \mathrm{H} & 44 & -5.758 & 4.559 \\ \mathrm{H} & 45 & -2.936 & 5.209 \\ \mathrm{C} & 46 & -2.644 & 0.513 \\ \mathrm{H} & 47 & -2.227 & -1.479 \\ \mathrm{H} & 48 & -0.904 & 1.545 \\ \mathrm{H} & 49 & -3.782 & 0.904 \\ \mathrm{C} & 50 & 1.097 & -3.451 \\ \mathrm{C} & 51 & -1.180 & -5.122 \\ \mathrm{H} & 52 & -1.532 & -6.455 \\ \mathrm{H} & 53 & -2.855 & -3.993 \\ \mathrm{H} & 54 & -0.837 & -6.176 \\ \mathrm{C} & 55 & 1.553 & -1.582 \\ \mathrm{H} & 56 & 3.098 & -0.345 \\ \mathrm{H} & 57 & 2.006 & -2.589 \\ \mathrm{H} & 58 & -0.114 & -0.464 \\ \mathrm{C} & 59 & 3.442 & -5.102 \\ \mathrm{H} & 60 & 5.051 & -3.950 \\ \mathrm{H} & 61 & 3.143 & -6.437 \\ \mathrm{H} & 62 & 3.851 & -6.138\end{array}$

BCP 1

BCP 20.989

BCP $3 \quad 2.149$

BCP $4 \quad 1.371$

BCP $5 \quad-0.846$

BCP $6 \quad-3.150$

BCP $7 \quad 1.459$

BCP $8 \quad-0.786$

BCP 90.684

BCP $10 \quad 3.117$

BCP $11 \quad 3.281$

BCP 12

BCP 13

BCP 14

BCP 15

BCP 16

BCP 17

BCP 18

BCP 19

BCP 20

BCP 21

BCP 22

BCP 23

BCP 24

BCP 25

BCP 26

BCP 27

BCP 28

BCP 29

BCP 30

BCP 31

$-4.480$

$-4.467$

BCP $34 \quad 0.469$

BCP $35-0.313$

BCP $36 \quad 1.518$

BCP $37 \quad-3.462$

BCP $38 \quad-5.298$

ВСР $39 \quad-7.179$

BCP $40 \quad-6.271$

BCP $41-7.285$
$-3.824 \quad 4.472 \mathrm{E}-01-2.702 \mathrm{E}+01 \quad 1.668 \mathrm{E}-02 \quad 1.510 \mathrm{E}+01-9.234 \mathrm{E}+00 \quad-9.231 \mathrm{E}+00-8.553 \mathrm{E}+00$ $-7.121 \quad 4.462 \mathrm{E}-01-2.697 \mathrm{E}+01 \quad 1.664 \mathrm{E}-02 \quad 1.511 \mathrm{E}+01-9.216 \mathrm{E}+00-9.214 \mathrm{E}+00-8.535 \mathrm{E}+00$

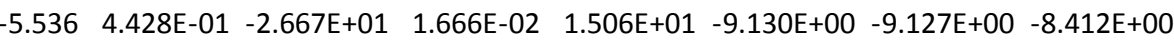

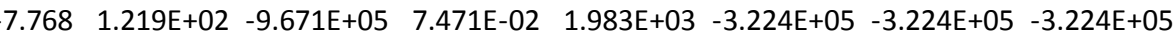
$-7.735 \quad 4.471 \mathrm{E}-01-2.700 \mathrm{E}+01 \quad 1.662 \mathrm{E}-02 \quad 1.510 \mathrm{E}+01-9.231 \mathrm{E}+00-9.228 \mathrm{E}+00-8.546 \mathrm{E}+00$ $-7.930 \quad 4.435 \mathrm{E}-01-2.672 \mathrm{E}+01 \quad 1.672 \mathrm{E}-02 \quad 1.506 \mathrm{E}+01-9.145 \mathrm{E}+00-9.142 \mathrm{E}+00-8.429 \mathrm{E}+00$ $-9.411 \quad 4.464 \mathrm{E}-01-2.698 \mathrm{E}+01 \quad 1.668 \mathrm{E}-02 \quad 1.511 \mathrm{E}+01-9.220 \mathrm{E}+00-9.219 \mathrm{E}+00-8.540 \mathrm{E}+00$

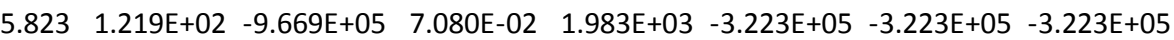
$6.442 \quad 1.219 E+02-9.672 E+05 \quad 7.452 E-02 \quad 1.983 E+03-3.224 E+05-3.224 E+05-3.224 E+05$ 4.940 4.457E-01 -2.694E+01 1.658E-02 1.511E+01 $-9.208 \mathrm{E}+00-9.205 \mathrm{E}+00-8.529 \mathrm{E}+00$ $6.722 \quad 4.457 \mathrm{E}-01-2.694 \mathrm{E}+01 \quad 1.654 \mathrm{E}-02 \quad 1.511 \mathrm{E}+01-9.207 \mathrm{E}+00-9.204 \mathrm{E}+00-8.525 \mathrm{E}+00$

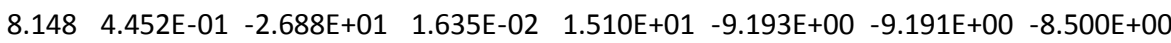

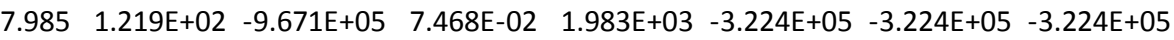
$7.535 \quad 4.427 \mathrm{E}-01-2.667 \mathrm{E}+01 \quad 1.665 \mathrm{E}-02 \quad 1.506 \mathrm{E}+01 \quad-9.129 \mathrm{E}+00-9.127 \mathrm{E}+00-8.411 \mathrm{E}+00$ $9.696 \quad 4.462 \mathrm{E}-01 \quad-2.696 \mathrm{E}+01 \quad 1.664 \mathrm{E}-02 \quad 1.511 \mathrm{E}+01-9.215 \mathrm{E}+00-9.214 \mathrm{E}+00 \quad-8.535 \mathrm{E}+00$

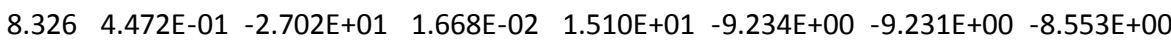

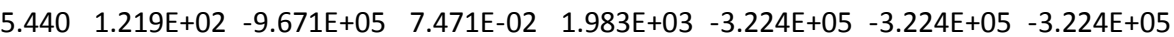
$4.986 \quad 4.435 \mathrm{E}-01-2.672 \mathrm{E}+01 \quad 1.673 \mathrm{E}-02 \quad 1.506 \mathrm{E}+01-9.145 \mathrm{E}+00-9.143 \mathrm{E}+00-8.429 \mathrm{E}+00$ $3.934 \quad 4.471 \mathrm{E}-01-2.701 \mathrm{E}+01 \quad 1.662 \mathrm{E}-02 \quad 1.510 \mathrm{E}+01-9.231 \mathrm{E}+00-9.228 \mathrm{E}+00-8.546 \mathrm{E}+00$

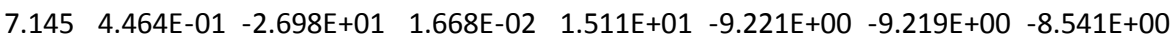

1.956 0.668 $-0.400$ 0.885 1.262 $-0.312$ $-0.858$ $-2.482$ 2.380 0.140 $-1.620$ $-2.489$ $-3.592$ $-3.489$ $-1.750$ $-1.243$ $-0.069$ 0.707 $-1.007$ $-3.354$ $-5.315$ $-4.238$ $-5.189$ 3.475 5.430 6.334 7.058 7.515 3.687 2.090 2.090
2.857 4.055 4.560 3.848 5.825 5.341 1.058 0.537 0.138 $-1.494$ 0.031

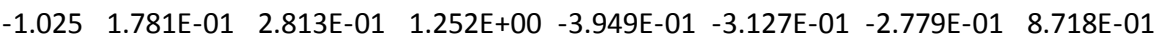
$\begin{array}{llllllll}-1.925 & 1.772 \mathrm{E}-01 & 2.374 \mathrm{E}-01 & 1.205 \mathrm{E}+00 & -3.348 \mathrm{E}-01 & -3.086 \mathrm{E}-01 & -2.753 \mathrm{E}-01 & 8.213 \mathrm{E}-01\end{array}$ $\begin{array}{llllllll}0.594 & 1.772 \mathrm{E}-01 & 2.374 \mathrm{E}-01 & 1.205 \mathrm{E}+00 & -3.349 \mathrm{E}-01 & -3.085 \mathrm{E}-01 & -2.753 \mathrm{E}-01 & 8.212 \mathrm{E}-01\end{array}$ $\begin{array}{llllllll}1.502 & 1.782 \mathrm{E}-01 & 2.819 \mathrm{E}-01 & 1.253 \mathrm{E}+00 & -3.956 \mathrm{E}-01 & -3.130 \mathrm{E}-01 & -2.782 \mathrm{E}-01 & 8.731 \mathrm{E}-01\end{array}$ $-2.560 \quad 1.881 \mathrm{E}-01 \quad 3.842 \mathrm{E}-01 \quad 1.358 \mathrm{E}+00 \quad-5.106 \mathrm{E}-01 \quad-3.582 \mathrm{E}-01 \quad-2.846 \mathrm{E}-01 \quad 1.027 \mathrm{E}+00$ $-2.265 \quad 3.406 \mathrm{E}-01-1.663 \mathrm{E}+00 \quad 1.819 \mathrm{E}-01 \quad 1.220 \mathrm{E}+00 \quad-1.296 \mathrm{E}+00 \quad-1.237 \mathrm{E}+00 \quad 8.702 \mathrm{E}-01$ $2.448 \quad 1.882 \mathrm{E}-01 \quad 3.845 \mathrm{E}-01 \quad 1.359 \mathrm{E}+00 \quad-5.109 \mathrm{E}-01 \quad-3.582 \mathrm{E}-01 \quad-2.846 \mathrm{E}-01 \quad 1.027 \mathrm{E}+00$ $2.891 \quad 3.406 \mathrm{E}-01-1.663 \mathrm{E}+00 \quad 1.819 \mathrm{E}-01 \quad 1.220 \mathrm{E}+00 \quad-1.296 \mathrm{E}+00 \quad-1.237 \mathrm{E}+00 \quad 8.702 \mathrm{E}-01$ $\begin{array}{llllllll}-2.984 & 2.447 \mathrm{E}-01 & 1.368 \mathrm{E}+00 & 2.176 \mathrm{E}+00 & -1.398 \mathrm{E}+00 & -4.519 \mathrm{E}-01 & -4.270 \mathrm{E}-01 & 2.247 \mathrm{E}+00\end{array}$

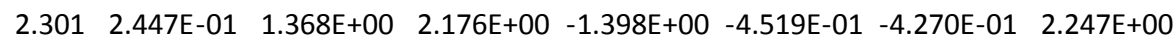
$\begin{array}{llllllll}-2.197 & 2.439 \mathrm{E}-01 & -5.765 \mathrm{E}-01 & 4.648 \mathrm{E}-01 & 5.910 \mathrm{E}-01 & -4.785 \mathrm{E}-01 & -4.679 \mathrm{E}-01 & 3.699 \mathrm{E}-01\end{array}$

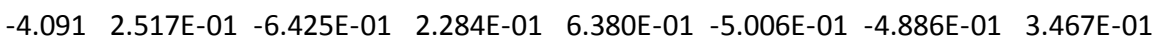

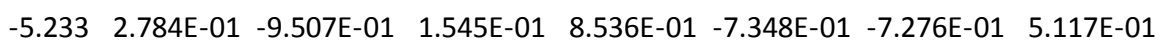

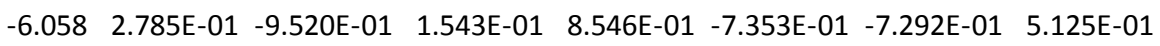
-6.038 2.816E-01 -9.712E-01 $1.492 \mathrm{E}-01 \quad 8.622 \mathrm{E}-01 \quad-7.508 \mathrm{E}-01 \quad-7.437 \mathrm{E}-01 \quad 5.233 \mathrm{E}-01$ $\begin{array}{llllllll}-2.941 & 2.492 \mathrm{E}-01 & -6.268 \mathrm{E}-01 & 2.305 \mathrm{E}-01 & 6.289 \mathrm{E}-01 & -4.932 \mathrm{E}-01 & -4.800 \mathrm{E}-01 & 3.464 \mathrm{E}-01\end{array}$ -1.910 2.813E-01 -9.724E-01 $1.457 \mathrm{E}-01 \quad 8.640 \mathrm{E}-01 \quad-7.527 \mathrm{E}-01 \quad-7.459 \mathrm{E}-01 \quad 5.263 \mathrm{E}-01$ -3.734 2.813E-01 -9.722E-01 $1.458 \mathrm{E}-01 \quad 8.639 \mathrm{E}-01 \quad-7.525 \mathrm{E}-01 \quad-7.458 \mathrm{E}-01 \quad 5.261 \mathrm{E}-01$

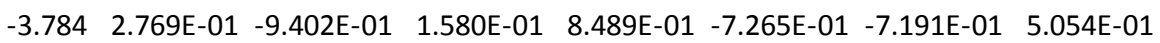

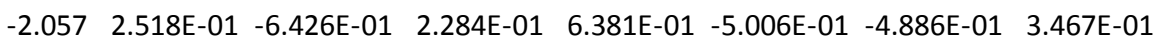

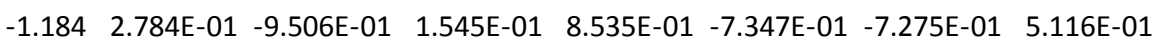

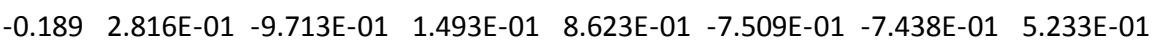

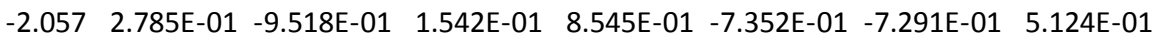

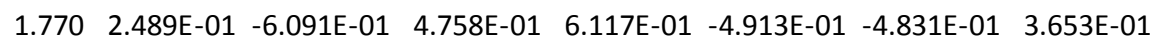

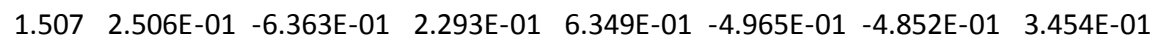

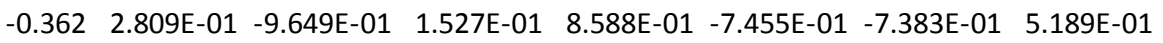
$0.343 \quad 2.811 \mathrm{E}-01 \quad-9.712 \mathrm{E}-01 \quad 1.458 \mathrm{E}-01 \quad 8.637 \mathrm{E}-01 \quad-7.521 \mathrm{E}-01 \quad-7.454 \mathrm{E}-01 \quad 5.263 \mathrm{E}-01$

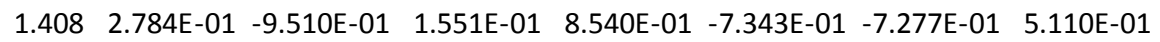
$2.718 \quad 2.495 \mathrm{E}-01 \quad-6.307 \mathrm{E}-01 \quad 2.269 \mathrm{E}-01 \quad 6.319 \mathrm{E}-01 \quad-4.963 \mathrm{E}-01 \quad-4.820 \mathrm{E}-01 \quad 3.476 \mathrm{E}-01$ $3.825 \quad 2.793 \mathrm{E}-01 \quad-9.555 \mathrm{E}-01 \quad 1.540 \mathrm{E}-01 \quad 8.554 \mathrm{E}-01 \quad-7.376 \mathrm{E}-01 \quad-7.319 \mathrm{E}-01 \quad 5.140 \mathrm{E}-01$

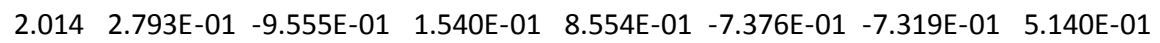
$\begin{array}{llllllll}3.776 & 2.781 \mathrm{E}-01 & -9.489 \mathrm{E}-01 & 1.544 \mathrm{E}-01 & 8.532 \mathrm{E}-01 & -7.329 \mathrm{E}-01 & -7.276 \mathrm{E}-01 & 5.115 \mathrm{E}-01\end{array}$

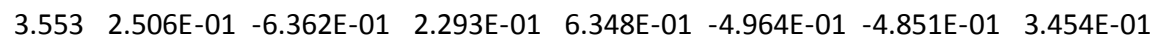

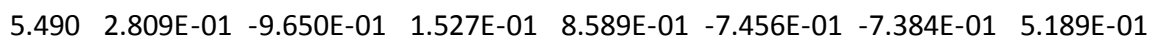

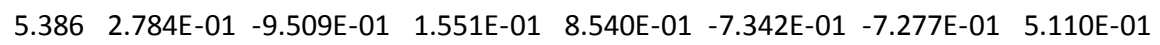
$4.379 \quad 2.811 \mathrm{E}-01 \quad-9.713 \mathrm{E}-01 \quad 1.458 \mathrm{E}-01 \quad 8.637 \mathrm{E}-01 \quad-7.521 \mathrm{E}-01 \quad-7.454 \mathrm{E}-01 \quad 5.263 \mathrm{E}-01$

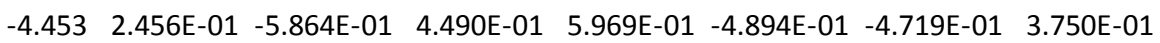
$\begin{array}{llllllll}-5.253 & 2.507 \mathrm{E}-01 & -6.371 \mathrm{E}-01 & 2.278 \mathrm{E}-01 & 6.354 \mathrm{E}-01 & -4.964 \mathrm{E}-01 & -4.866 \mathrm{E}-01 & 3.459 \mathrm{E}-01\end{array}$ $-4.072 \quad 2.778 \mathrm{E}-01 \quad-9.465 \mathrm{E}-01 \quad 1.537 \mathrm{E}-01 \quad 8.518 \mathrm{E}-01 \quad-7.330 \mathrm{E}-01 \quad-7.253 \mathrm{E}-01 \quad 5.118 \mathrm{E}-01$

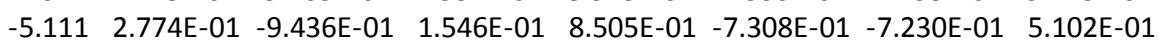

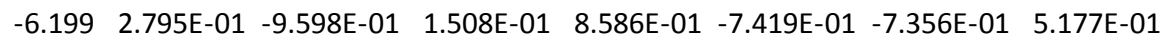


ВCP $42 \quad-4.361$ BCP $43-5.341$ BCP $44 \quad-5.365$ BCP $45-3.532$ BCP $46-3.335$ BCP $47-2.380$ ВCP $48-1.510$ BCP $49-3.383$ BCP $50 \quad 0.837$ BCP $51-0.056$ BCP $52-1.403$ BCP $53-2.256$ BCP $54 \quad-0.953$ BCP 551.326 BCP $56 \quad 2.561$ $-0.776$ $\begin{array}{llll}\text { BCP } 57 & 1.843 & -2.238\end{array}$ $\begin{array}{lll}\text { BCP } 58 & 0.477 & -0.867\end{array}$ $\begin{array}{lll}\text { BCP } 59 & 2.290 & -4.290\end{array}$

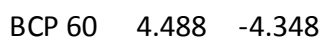
$\begin{array}{lll}\text { BCP } 61 & 3.242 & -5.959\end{array}$ BCP $62 \quad 3.698-5.766$
$2.740 \quad-5.411 \quad 2.505 \mathrm{E}-01 \quad-6.354 \mathrm{E}-01 \quad 2.280 \mathrm{E}-01 \quad 6.343 \mathrm{E}-01 \quad-4.988 \mathrm{E}-01 \quad-4.840 \mathrm{E}-01 \quad 3.473 \mathrm{E}-01$ $\begin{array}{lllllllll}4.483 & -4.407 & 2.781 \mathrm{E}-01 & -9.480 \mathrm{E}-01 & 1.563 \mathrm{E}-01 & 8.522 \mathrm{E}-01 & -7.326 \mathrm{E}-01 & -7.244 \mathrm{E}-01 & 5.091 \mathrm{E}-01\end{array}$ $\begin{array}{lllllllll}4.398 & -6.532 & 2.778 \mathrm{E}-01 & -9.466 \mathrm{E}-01 & 1.558 \mathrm{E}-01 & 8.518 \mathrm{E}-01 & -7.317 \mathrm{E}-01 & -7.243 \mathrm{E}-01 & 5.094 \mathrm{E}-01\end{array}$ $\begin{array}{lllllllll}4.831 & -5.510 & 2.827 \mathrm{E}-01 & -9.823 \mathrm{E}-01 & 1.430 \mathrm{E}-01 & 8.687 \mathrm{E}-01 & -7.603 \mathrm{E}-01 & -7.544 \mathrm{E}-01 & 5.324 \mathrm{E}-01\end{array}$ $\begin{array}{lllllllll}0.895 & -6.586 & 2.504 \mathrm{E}-01 & -6.342 \mathrm{E}-01 & 2.285 \mathrm{E}-01 & 6.334 \mathrm{E}-01 & -4.981 \mathrm{E}-01 & -4.836 \mathrm{E}-01 & 3.475 \mathrm{E}-01\end{array}$ $\begin{array}{lllllllll}-0.770 & -7.740 & 2.788 \mathrm{E}-01 & -9.526 \mathrm{E}-01 & 1.550 \mathrm{E}-01 & 8.543 \mathrm{E}-01 & -7.361 \mathrm{E}-01 & -7.282 \mathrm{E}-01 & 5.116 \mathrm{E}-01\end{array}$ $1.187 \quad-7.870 \quad 2.827 \mathrm{E}-01 \quad-9.813 \mathrm{E}-01 \quad 1.441 \mathrm{E}-01 \quad 8.679 \mathrm{E}-01 \quad-7.592 \mathrm{E}-01 \quad-7.533 \mathrm{E}-01 \quad 5.312 \mathrm{E}-01$ $\begin{array}{lllllllll}0.766 & -8.819 & 2.777 \mathrm{E}-01 & -9.456 \mathrm{E}-01 & 1.564 \mathrm{E}-01 & 8.513 \mathrm{E}-01 & -7.308 \mathrm{E}-01 & -7.238 \mathrm{E}-01 & 5.090 \mathrm{E}-01\end{array}$ $\begin{array}{lllllllll}-2.899 & 4.881 & 2.456 \mathrm{E}-01 & -5.867 \mathrm{E}-01 & 4.491 \mathrm{E}-01 & 5.971 \mathrm{E}-01 & -4.896 \mathrm{E}-01 & -4.720 \mathrm{E}-01 & 3.750 \mathrm{E}-01\end{array}$ $\begin{array}{lllllllll}-4.289 & 6.126 & 2.507 \mathrm{E}-01 & -6.374 \mathrm{E}-01 & 2.278 \mathrm{E}-01 & 6.355 \mathrm{E}-01 & -4.966 \mathrm{E}-01 & -4.868 \mathrm{E}-01 & 3.460 \mathrm{E}-01\end{array}$

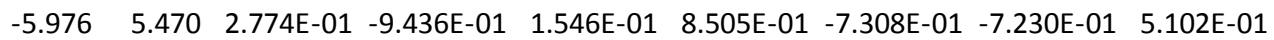
$\begin{array}{lllllllll}-4.389 & 6.619 & 2.778 \mathrm{E}-01 & -9.464 \mathrm{E}-01 & 1.537 \mathrm{E}-01 & 8.518 \mathrm{E}-01 & -7.330 \mathrm{E}-01 & -7.253 \mathrm{E}-01 & 5.118 \mathrm{E}-01\end{array}$ $\begin{array}{lllllllll}-5.800 & 7.545 & 2.795 \mathrm{E}-01 & -9.598 \mathrm{E}-01 & 1.508 \mathrm{E}-01 & 8.586 \mathrm{E}-01 & -7.419 \mathrm{E}-01 & -7.356 \mathrm{E}-01 & 5.177 \mathrm{E}-01\end{array}$ 6.919 2.504E-01 -6.353E-01 2.280E-01 6.342E-01 -4.987E-01 -4.839E-01 3.473E-01

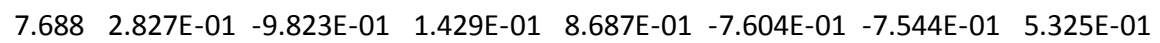

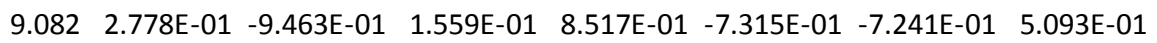
8.199 2.781E-01 -9.478E-01 1.563E-01 8.521E-01 -7.325E-01 -7.243E-01 5.090E-01

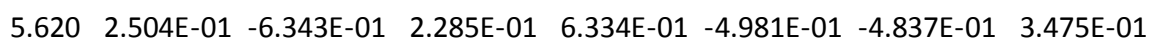
$\begin{array}{llllllll}5.144 & 2.826 \mathrm{E}-01 & -9.812 \mathrm{E}-01 & 1.442 \mathrm{E}-01 & 8.679 \mathrm{E}-01 & -7.591 \mathrm{E}-01 & -7.532 \mathrm{E}-01 & 5.311 \mathrm{E}-01\end{array}$ $4.470 \quad 2.788 \mathrm{E}-01 \quad-9.526 \mathrm{E}-01 \quad 1.550 \mathrm{E}-01 \quad 8.543 \mathrm{E}-01 \quad-7.361 \mathrm{E}-01 \quad-7.282 \mathrm{E}-01 \quad 5.117 \mathrm{E}-01$

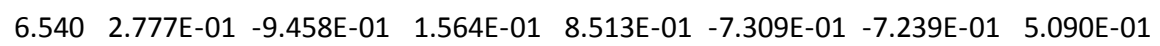

RCP $1-3.102$ RCP $2 \quad-1.519$ RCP $3 \quad 0.765$ RCP $4 \quad 4.757$ RCP $5 \quad 3.615$ RCP $6 \quad 5.208$ RCP $7 \quad-2.794$ RCP 80.873 RCP $9 \quad-1.723 \quad 3.475$ RCP $10-0.777 \quad 1.796$ RCP $11 \quad 2.752 \quad-0.644$ RCP $12 \quad 3.658-2.292$

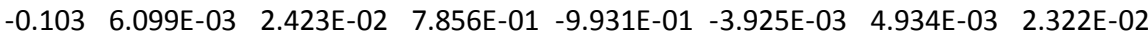
$\begin{array}{llllllll}3.331 & 6.115 \mathrm{E}-03 & 2.435 \mathrm{E}-02 & 7.876 \mathrm{E}-01 & -9.956 \mathrm{E}-01 & -3.920 \mathrm{E}-03 & 5.024 \mathrm{E}-03 & 2.325 \mathrm{E}-02\end{array}$ $\begin{array}{llllllll}-6.145 & 4.359 \mathrm{E}-03 & 1.572 \mathrm{E}-02 & 7.081 \mathrm{E}-01 & -9.015 \mathrm{E}-01 & -1.972 \mathrm{E}-03 & 6.601 \mathrm{E}-03 & 1.109 \mathrm{E}-02\end{array}$ $2.528 \quad 4.393 \mathrm{E}-03 \quad 1.579 \mathrm{E}-02 \quad 7.069 \mathrm{E}-01 \quad-8.988 \mathrm{E}-01 \quad-1.989 \mathrm{E}-03 \quad 6.748 \mathrm{E}-03 \quad 1.103 \mathrm{E}-02$

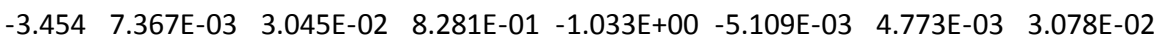
$\begin{array}{llllllll}0.014 & 7.396 \mathrm{E}-03 & 3.061 \mathrm{E}-02 & 8.295 \mathrm{E}-01 & -1.035 \mathrm{E}+00 & -5.132 \mathrm{E}-03 & 4.884 \mathrm{E}-03 & 3.085 \mathrm{E}-02\end{array}$

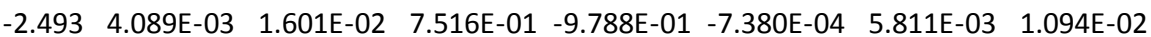
$5.534 \quad 4.090 \mathrm{E}-03 \quad 1.603 \mathrm{E}-02 \quad 7.515 \mathrm{E}-01 \quad-9.795 \mathrm{E}-01 \quad-8.093 \mathrm{E}-04 \quad 5.806 \mathrm{E}-03 \quad 1.103 \mathrm{E}-02$

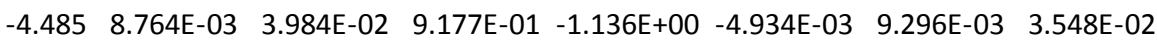

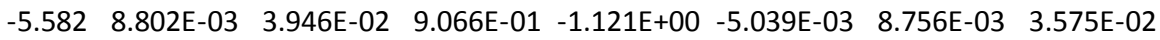
$\begin{array}{llllllll}5.216 & 8.770 \mathrm{E}-03 & 3.986 \mathrm{E}-02 & 9.178 \mathrm{E}-01 & -1.136 \mathrm{E}+00 & -4.950 \mathrm{E}-03 & 9.319 \mathrm{E}-03 & 3.549 \mathrm{E}-02\end{array}$

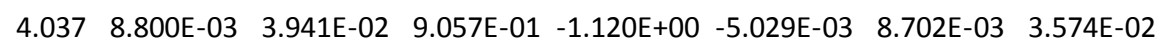

AIM analysis of $\mathbf{2 b}$ :

Point $\quad X \quad Y \quad Z \quad$ Density Laplacian $\quad G(r) / D(r) \quad K(r) / D(r) \quad E V(1) \quad E V(2) \quad E V(3)$

\begin{tabular}{|c|c|c|c|c|c|c|c|c|c|c|c|}
\hline & 1 & 0.327 & 226 & .898 & $219 E+02$ & $-9.671 E+05$ & $481 \mathrm{E}-02$ & כטדTS & & $4 \mathrm{E}+0$ & +05 \\
\hline & 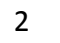 & & & & +02 & $E+05$ & 02 & +03 & $=+05$ & $=+U 3$ & +05 \\
\hline & 3 & & & & & $E+05$ & & & & & \\
\hline & 4 & & & & & & & & & & +05 \\
\hline & 5 & 2.392 & 0.153 & .523 & $E+03$ & $4 \mathrm{E}+07$ & $E+00$ & $E+03$ & $E+07$ & $\mathrm{E}+07$ & $E+07$ \\
\hline & 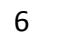 & 663 & 0 & & & +08 & -00 & & & +07 & +07 \\
\hline & 7 & & & & & & & & & 05 & +05 \\
\hline & 8 & -2.393 & 9 & & & +07 & +00 & +03 & +07 & +07 & $E+07$ \\
\hline & 9 & -3.851 & & & & +06 & 01 & & & & $=05$ \\
\hline & 10 & -6.543 & -0.372 & 28 & 02 & $E+05$ & -02 & +03 & & TUS & $E+05$ \\
\hline & 11 & -6.493 & -0.355 & 22 & & $2 \mathrm{E}+05$ & $E-02$ & +03 & J & $=05$ & $E+05$ \\
\hline & 12 & & & & & +06 & $=-01$ & & & & $E+05$ \\
\hline & 13 & -0.300 & 4.888 & & & $=05$ & -02 & & & +05 & $E+05$ \\
\hline & 14 & -2.730 & 5.914 & -0.727 & $9 \mathrm{E}+02$ & $2 \mathrm{E}+05$ & $\mathrm{E}-02$ & $1.983 E+03$ & $E+05$ & $E+05$ & $E+05$ \\
\hline & 15 & 664 & 292 & 80 & +03 & $3 E+08$ & $E+00$ & $E+04$ & 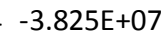 & $5 E+07$ & $\mathrm{E}+07$ \\
\hline & 16 & 1.981 & 6.204 & & $E+02$ & $E+05$ & $=-02$ & +03 & $E+05$ & $E+05$ & $\mathrm{E}+05$ \\
\hline & 17 & -0.328 & 5.339 & -4.770 & $9 \mathrm{E}+02$ & $E+05$ & $E-02$ & $83 \mathrm{E}+03$ & $\mathrm{E}+05$ & $4 \mathrm{E}+05$ & $4 \mathrm{E}+05$ \\
\hline & 18 & 3.851 & 0.120 & 42 & $1.980 \mathrm{E}+02$ & $E+06$ & $5 E-01$ & $E+03$ & $E+05$ & $9 \mathrm{E}+05$ & $8 \mathrm{E}+05$ \\
\hline & 19 & 6.543 & 0.324 & 2.035 & $1.219 \mathrm{E}+02$ & $-9.669 E+05$ & 7.070E-02 & $1.983 \mathrm{E}+03$ & $-3.223 E+05$ & $-3.223 E+05$ & $-3.223 E+05$ \\
\hline
\end{tabular}




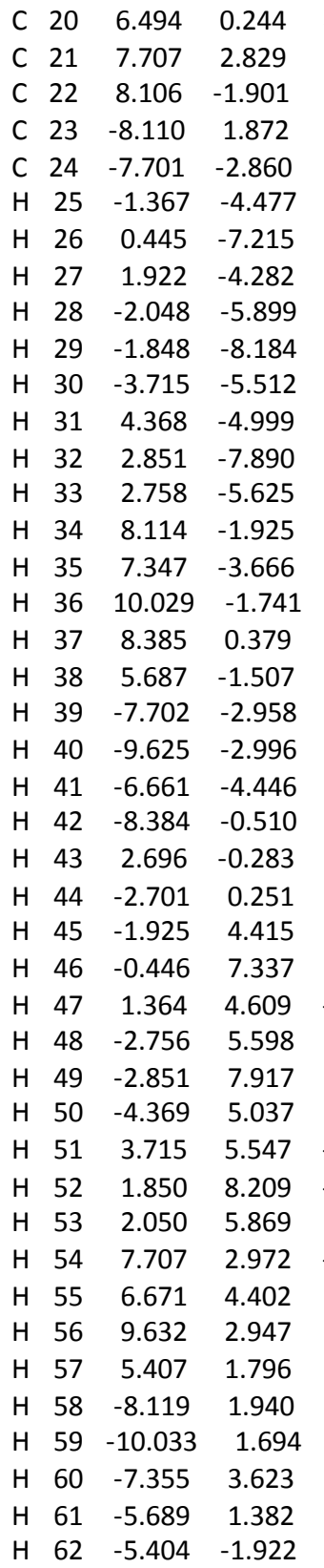

$\begin{array}{llll}\text { BCP } & 1 & 0.313 & -5.033\end{array}$

$\begin{array}{llll}B C P & 2 & 1.534 & -5.366\end{array}$

$\begin{array}{lll}\text { BCP } 3 & 0.231 & -3.765\end{array}$

$\begin{array}{lll}\text { BCP } 4 & 1.553 & -0.777\end{array}$

$\begin{array}{lll}\text { BCP } 5 & 3.294 & 0.249\end{array}$

$\begin{array}{lll}\text { BCP } 6 & -0.861 & -5.516\end{array}$

$\begin{array}{lll}\text { BCP } 7 & -1.451 & -0.949\end{array}$

$\begin{array}{lll}\text { BCP } 8 & -2.985 & -0.128\end{array}$

$\begin{array}{llll}\text { BCP } 9 & -5.474 & -0.281\end{array}$

BCP $10-6.505-0.362$

$\begin{array}{lll}\text { BCP } 11 & 1.450 & 0.983\end{array}$

$\begin{array}{lll}\text { BCP } 12 & -1.554 & 0.811\end{array}$

$\begin{array}{lll}\text { BCP } 13 & -0.232 & 3.805\end{array}$

$\begin{array}{lll}\text { BCP } 14 & -1.534 & 5.398\end{array}$

BCP $15-3.295$

BCP $16 \quad 0.861$

BCP $17 \quad-0.314$

BCP $18 \quad 2.984$

BCP $19 \quad 5.474$

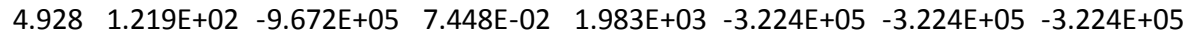

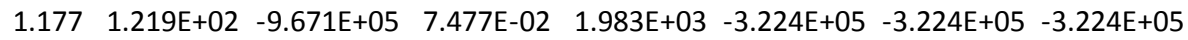
$\begin{array}{llllllll}1.043 & 1.219 E+02 & -9.671 E+05 & 7.474 E-02 & 1.983 E+03 & -3.224 E+05 & -3.224 E+05 & -3.224 E+05\end{array}$ $\begin{array}{llllllll}1.085 & 1.219 \mathrm{E}+02 & -9.671 \mathrm{E}+05 & 7.473 \mathrm{E}-02 & 1.983 \mathrm{E}+03 & -3.224 \mathrm{E}+05 & -3.224 \mathrm{E}+05 & -3.224 \mathrm{E}+05\end{array}$

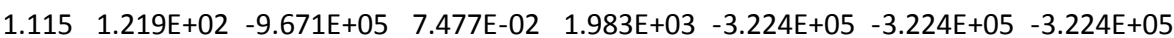

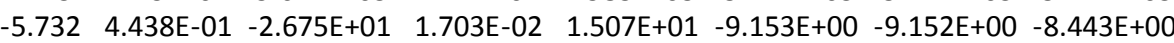
$-5.327 \quad 4.462 \mathrm{E}-01-2.697 \mathrm{E}+01 \quad 1.680 \mathrm{E}-02 \quad 1.511 \mathrm{E}+01-9.217 \mathrm{E}+00-9.215 \mathrm{E}+00-8.541 \mathrm{E}+00$ $-5.727 \quad 4.439 \mathrm{E}-01-2.676 \mathrm{E}+01 \quad 1.694 \mathrm{E}-02 \quad 1.507 \mathrm{E}+01-9.156 \mathrm{E}+00-9.154 \mathrm{E}+00-8.448 \mathrm{E}+00$

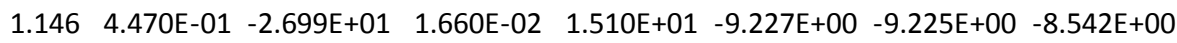
$-1.235 \quad 4.457 \mathrm{E}-01-2.692 \mathrm{E}+01 \quad 1.654 \mathrm{E}-02 \quad 1.510 \mathrm{E}+01-9.204 \mathrm{E}+00-9.202 \mathrm{E}+00 \quad-8.517 \mathrm{E}+00$ $-1.681 \quad 4.458 \mathrm{E}-01-2.688 \mathrm{E}+01 \quad 1.706 \mathrm{E}-02 \quad 1.507 \mathrm{E}+01-9.195 \mathrm{E}+00-9.193 \mathrm{E}+00-8.490 \mathrm{E}+00$

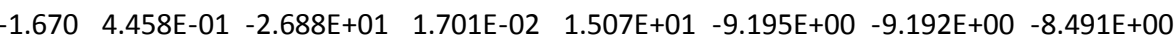
$-1.257 \quad 4.457 \mathrm{E}-01-2.693 \mathrm{E}+01 \quad 1.654 \mathrm{E}-02 \quad 1.510 \mathrm{E}+01-9.205 \mathrm{E}+00-9.203 \mathrm{E}+00-8.518 \mathrm{E}+00$ $1.147 \quad 4.473 \mathrm{E}-01-2.701 \mathrm{E}+01 \quad 1.663 \mathrm{E}-02 \quad 1.510 \mathrm{E}+01-9.233 \mathrm{E}+00-9.231 \mathrm{E}+00-8.550 \mathrm{E}+00$

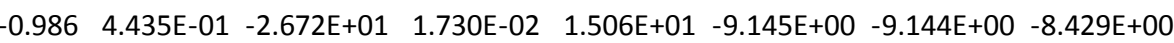
$\begin{array}{llllllll}1.715 & 4.474 \mathrm{E}-01 & -2.702 \mathrm{E}+01 & 1.669 \mathrm{E}-02 & 1.510 \mathrm{E}+01 & -9.236 \mathrm{E}+00 & -9.234 \mathrm{E}+00 & -8.551 \mathrm{E}+00\end{array}$ $1.695 \quad 4.462 \mathrm{E}-01-2.697 \mathrm{E}+01 \quad 1.672 \mathrm{E}-02 \quad 1.511 \mathrm{E}+01-9.217 \mathrm{E}+00-9.215 \mathrm{E}+00-8.537 \mathrm{E}+00$ $5.663 \quad 4.452 \mathrm{E}-01-2.688 \mathrm{E}+01 \quad 1.636 \mathrm{E}-02 \quad 1.510 \mathrm{E}+01-9.193 \mathrm{E}+00-9.191 \mathrm{E}+00-8.499 \mathrm{E}+00$ $5.595 \quad 4.458 \mathrm{E}-01-2.695 \mathrm{E}+01 \quad 1.659 \mathrm{E}-02 \quad 1.511 \mathrm{E}+01-9.210 \mathrm{E}+00 \quad-9.206 \mathrm{E}+00-8.531 \mathrm{E}+00$ $-0.911 \quad 4.438 \mathrm{E}-01-2.673 \mathrm{E}+01 \quad 1.740 \mathrm{E}-02 \quad 1.506 \mathrm{E}+01-9.150 \mathrm{E}+00-9.148 \mathrm{E}+00-8.432 \mathrm{E}+00$

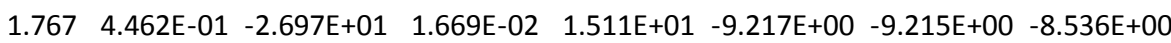

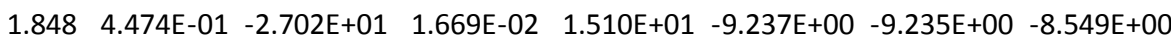
$5.654 \quad 4.452 \mathrm{E}-01-2.688 \mathrm{E}+01 \quad 1.636 \mathrm{E}-02 \quad 1.510 \mathrm{E}+01-9.193 \mathrm{E}+00-9.191 \mathrm{E}+00-8.499 \mathrm{E}+00$ $\begin{array}{llllllll}2.659 & 4.360 \mathrm{E}-01 & -2.552 \mathrm{E}+01 & 4.181 \mathrm{E}-02 & 1.463 \mathrm{E}+01 & -8.880 \mathrm{E}+00 & -8.860 \mathrm{E}+00 & -7.776 \mathrm{E}+00\end{array}$ $\begin{array}{llllllll}2.662 & 4.360 \mathrm{E}-01 & -2.552 \mathrm{E}+01 & 4.182 \mathrm{E}-02 & 1.463 \mathrm{E}+01 & -8.880 \mathrm{E}+00 & -8.860 \mathrm{E}+00 & -7.776 \mathrm{E}+00\end{array}$ $-5.621 \quad 4.439 \mathrm{E}-01-2.676 \mathrm{E}+01 \quad 1.694 \mathrm{E}-02 \quad 1.507 \mathrm{E}+01-9.156 \mathrm{E}+00-9.154 \mathrm{E}+00-8.448 \mathrm{E}+00$

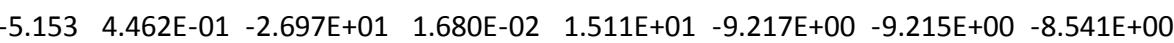

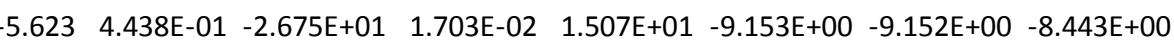

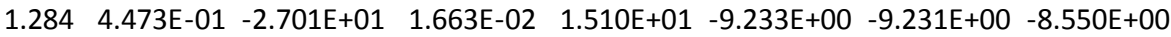

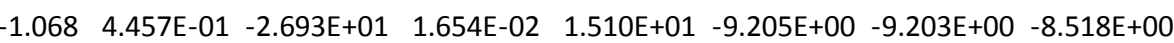
$-1.546 \quad 4.458 \mathrm{E}-01 \quad-2.688 \mathrm{E}+01 \quad 1.701 \mathrm{E}-02 \quad 1.507 \mathrm{E}+01 \quad-9.194 \mathrm{E}+00-9.192 \mathrm{E}+00-8.490 \mathrm{E}+00$ $-1.549 \quad 4.458 \mathrm{E}-01-2.688 \mathrm{E}+01 \quad 1.706 \mathrm{E}-02 \quad 1.507 \mathrm{E}+01-9.195 \mathrm{E}+00-9.192 \mathrm{E}+00-8.490 \mathrm{E}+00$

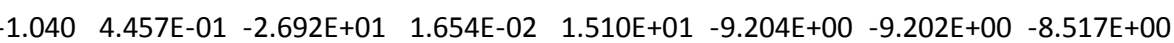

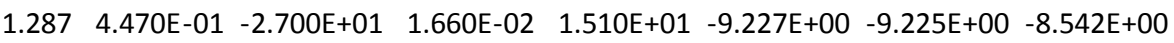
$-0.847 \quad 4.437 \mathrm{E}-01-2.673 \mathrm{E}+01 \quad 1.740 \mathrm{E}-02 \quad 1.506 \mathrm{E}+01-9.149 \mathrm{E}+00-9.147 \mathrm{E}+00-8.432 \mathrm{E}+00$

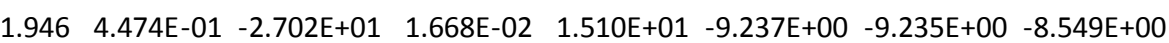

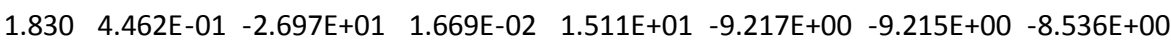

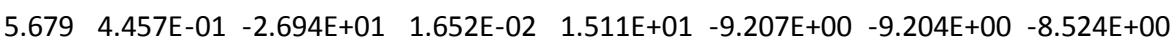
$-0.943 \quad 4.435 \mathrm{E}-01-2.672 \mathrm{E}+01 \quad 1.730 \mathrm{E}-02 \quad 1.506 \mathrm{E}+01-9.145 \mathrm{E}+00 \quad-9.143 \mathrm{E}+00-8.429 \mathrm{E}+00$

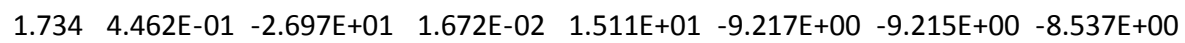
$1.795 \quad 4.473 \mathrm{E}-01-2.702 \mathrm{E}+01 \quad 1.669 \mathrm{E}-02 \quad 1.510 \mathrm{E}+01-9.236 \mathrm{E}+00-9.234 \mathrm{E}+00-8.551 \mathrm{E}+00$ $5.627 \quad 4.458 \mathrm{E}-01-2.695 \mathrm{E}+01 \quad 1.660 \mathrm{E}-02 \quad 1.511 \mathrm{E}+01-9.210 \mathrm{E}+00-9.207 \mathrm{E}+00-8.532 \mathrm{E}+00$

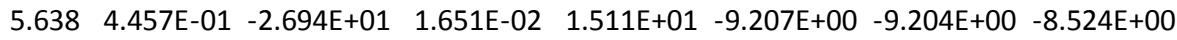

-3.498 2.491E-01 -6.270E-01 2.304E-01 6.292E-01 -4.936E-01 -4.798E-01 3.463E-01

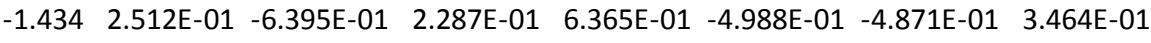
-1.784 2.443E-01 -5.830E-01 4.757E-01 5.966E-01 -4.789E-01 -4.674E-01 3.634E-01 $\begin{array}{llllllll}-1.497 & 1.756 \mathrm{E}-01 & 2.411 \mathrm{E}-01 & 1.209 \mathrm{E}+00 & -3.432 \mathrm{E}-01 & -2.970 \mathrm{E}-01 & -2.632 \mathrm{E}-01 & 8.013 \mathrm{E}-01\end{array}$ -2.649 1.788E-01 -3.342E-01 5.053E-01 4.673E-01 -2.031E-01 -1.829E-01 5.186E-02 $\begin{array}{llllllll}-1.433 & 2.514 \mathrm{E}-01 & -6.404 \mathrm{E}-01 & 2.288 \mathrm{E}-01 & 6.369 \mathrm{E}-01 & -4.994 \mathrm{E}-01 & -4.876 \mathrm{E}-01 & 3.465 \mathrm{E}-01\end{array}$ $\begin{array}{llllllll}-1.498 & 1.740 \mathrm{E}-01 & 2.279 \mathrm{E}-01 & 1.193 \mathrm{E}+00 & -3.273 \mathrm{E}-01 & -2.922 \mathrm{E}-01 & -2.607 \mathrm{E}-01 & 7.808 \mathrm{E}-01\end{array}$ $\begin{array}{llllllll}-0.452 & 1.866 \mathrm{E}-01 & 3.815 \mathrm{E}-01 & 1.357 \mathrm{E}+00 & -5.110 \mathrm{E}-01 & -3.436 \mathrm{E}-01 & -2.766 \mathrm{E}-01 & 1.002 \mathrm{E}+00\end{array}$

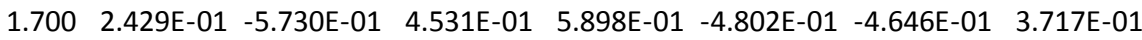
$\begin{array}{llllllll}3.487 & 2.502 \mathrm{E}-01 & -6.342 \mathrm{E}-01 & 2.277 \mathrm{E}-01 & 6.337 \mathrm{E}-01 & -4.951 \mathrm{E}-01 & -4.852 \mathrm{E}-01 & 3.461 \mathrm{E}-01\end{array}$ $\begin{array}{llllllll}-1.474 & 1.740 \mathrm{E}-01 & 2.272 \mathrm{E}-01 & 1.192 \mathrm{E}+00 & -3.264 \mathrm{E}-01 & -2.920 \mathrm{E}-01 & -2.606 \mathrm{E}-01 & 7.797 \mathrm{E}-01\end{array}$ $\begin{array}{llllllll}-1.478 & 1.756 \mathrm{E}-01 & 2.405 \mathrm{E}-01 & 1.208 \mathrm{E}+00 & -3.425 \mathrm{E}-01 & -2.969 \mathrm{E}-01 & -2.632 \mathrm{E}-01 & 8.006 \mathrm{E}-01\end{array}$ $\begin{array}{llllllll}-1.692 & 2.442 \mathrm{E}-01 & -5.828 \mathrm{E}-01 & 4.756 \mathrm{E}-01 & 5.965 \mathrm{E}-01 & -4.789 \mathrm{E}-01 & -4.674 \mathrm{E}-01 & 3.635 \mathrm{E}-01\end{array}$ $\begin{array}{llllllll}-1.304 & 2.512 \mathrm{E}-01 & -6.395 \mathrm{E}-01 & 2.287 \mathrm{E}-01 & 6.364 \mathrm{E}-01 & -4.988 \mathrm{E}-01 & -4.871 \mathrm{E}-01 & 3.464 \mathrm{E}-01\end{array}$ $\begin{array}{llllllll}-2.654 & 1.788 \mathrm{E}-01 & -3.341 \mathrm{E}-01 & 5.054 \mathrm{E}-01 & 4.672 \mathrm{E}-01 & -2.031 \mathrm{E}-01 & -1.829 \mathrm{E}-01 & 5.192 \mathrm{E}-02\end{array}$ $\begin{array}{lllllllll}5.546 & -1.300 & 2.514 \mathrm{E}-01 & -6.404 \mathrm{E}-01 & 2.288 \mathrm{E}-01 & 6.369 \mathrm{E}-01 & -4.994 \mathrm{E}-01 & -4.876 \mathrm{E}-01 & 3.465 \mathrm{E}-01\end{array}$ $\begin{array}{lllllllll}5.113 & -3.376 & 2.491 \mathrm{E}-01 & -6.270 \mathrm{E}-01 & 2.304 \mathrm{E}-01 & 6.292 \mathrm{E}-01 & -4.936 \mathrm{E}-01 & -4.797 \mathrm{E}-01 & 3.463 \mathrm{E}-01\end{array}$ $\begin{array}{lllllllll}0.139 & -0.449 & 1.867 \mathrm{E}-01 & 3.820 \mathrm{E}-01 & 1.357 \mathrm{E}+00 & -5.117 \mathrm{E}-01 & -3.437 \mathrm{E}-01 & -2.767 \mathrm{E}-01 & 1.002 \mathrm{E}+00\end{array}$

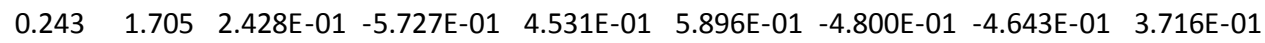


BCP $20 \quad 6.506$

BCP $21 \quad 7.128$

BCP $22 \quad 7.332$

BCP $23 \quad-7.335$

BCP $24 \quad-7.125$

BCP $25 \quad-0.778$

BCP $26 \quad 0.403$

BCP $27 \quad 1.367$

BCP $28-2.019$

BCP $29-1.888$

BCP $30 \quad-3.102$

BCP $31 \quad 3.788$

BCP 32

BCP 33

BCP 34

BCP 35

BCP 36

BCP 37

BCP 38

BCP 39

BCP 40

BCP 41

BCP 42

BCP 4

BCP 44

BCP 45

BCP 46

BCP 47

BCP 48

BCP 49

BCP 50

BCP 51

BCP 52

BCP 53

BCP 54

BCP 55

BCP 56

BCP 57

BCP 58

BCP 59

BCP 60

BCP $61-5.972$

BCP $62 \quad-5.788$

RCP 12.181

RCP $2-1.813$

RCP $3 \quad 4.976$

RCP $4 \quad-5.136$

$\begin{array}{ll}\text { RCP } 5 & -4.981\end{array}$

$\begin{array}{ll}\text { RCP } & 1.812\end{array}$

$\begin{array}{ll}\text { RCP } 7 & -2.183\end{array}$

RCP 85.138

RCP 95.963

RCP $10 \quad 5.751$

RCP $11-5.966$

RCP $12 \quad-5.748$
0.282 1.605 $-0.813$

0.775

$-1.644$

$-4.739$

$-6.505$

$-4.612$

$-5.998$

$-7.474$

$-5.744$

$-5.309$

$-7.181$

$-5.718$

$-1.914$

$-3.033$

$-1.791$

0.332

$-0.885$

$-2.920$

$-2.940$

$-3.877$

$-0.455$

$-0.182$

0.152

4.738

6.624

4.864

5.708

7.205

5.341

5.773

7.496

5.985

2.919

3.837

2.897

1.246

1.913

1.750

2.995

0.764

$-1.367$

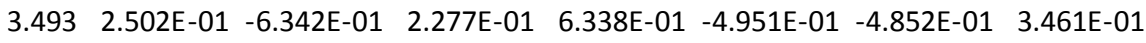
$\begin{array}{llllllll}1.593 & 2.505 \mathrm{E}-01 & -6.358 \mathrm{E}-01 & 2.288 \mathrm{E}-01 & 6.345 \mathrm{E}-01 & -4.984 \mathrm{E}-01 & -4.840 \mathrm{E}-01 & 3.466 \mathrm{E}-01\end{array}$ $\begin{array}{llllllll}1.526 & 2.501 \mathrm{E}-01 & -6.329 \mathrm{E}-01 & 2.284 \mathrm{E}-01 & 6.328 \mathrm{E}-01 & -4.975 \mathrm{E}-01 & -4.827 \mathrm{E}-01 & 3.472 \mathrm{E}-01\end{array}$ $\begin{array}{llllllll}1.545 & 2.500 \mathrm{E}-01 & -6.328 \mathrm{E}-01 & 2.284 \mathrm{E}-01 & 6.327 \mathrm{E}-01 & -4.974 \mathrm{E}-01 & -4.826 \mathrm{E}-01 & 3.473 \mathrm{E}-01\end{array}$

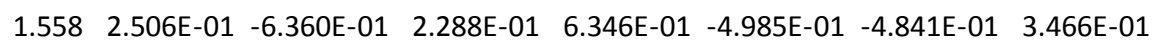

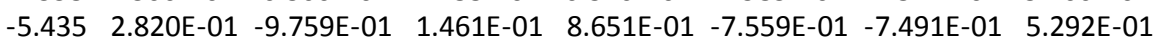

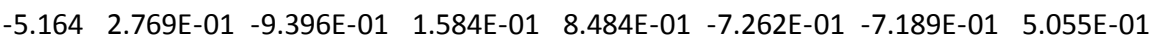

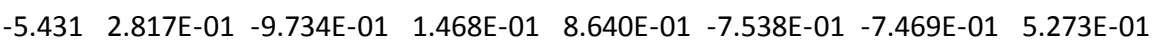
$0.429 \quad 2.788 \mathrm{E}-01 \quad-9.530 \mathrm{E}-01 \quad 1.543 \mathrm{E}-01 \quad 8.545 \mathrm{E}-01 \quad-7.364 \mathrm{E}-01 \quad-7.293 \mathrm{E}-01 \quad 5.127 \mathrm{E}-01$ $\begin{array}{llllllll}-1.108 & 2.785 \mathrm{E}-01 & -9.520 \mathrm{E}-01 & 1.542 \mathrm{E}-01 & 8.545 \mathrm{E}-01 & -7.353 \mathrm{E}-01 & -7.295 \mathrm{E}-01 & 5.128 \mathrm{E}-01\end{array}$

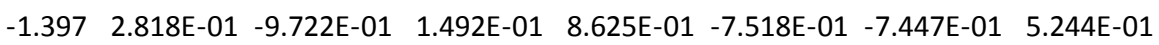

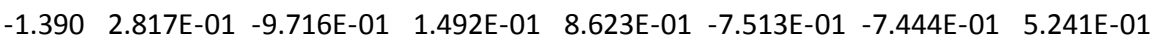

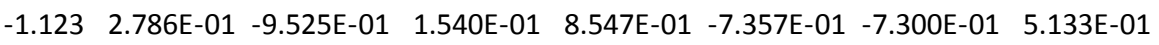

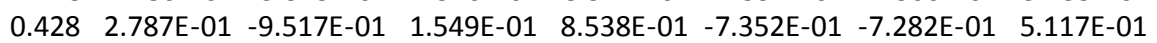

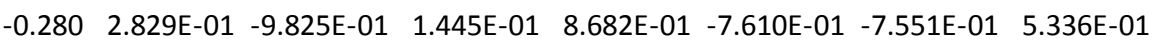
$\begin{array}{llllllll}1.480 & 2.790 \mathrm{E}-01 & -9.534 \mathrm{E}-01 & 1.552 \mathrm{E}-01 & 8.544 \mathrm{E}-01 & -7.368 \mathrm{E}-01 & -7.287 \mathrm{E}-01 & 5.121 \mathrm{E}-01\end{array}$

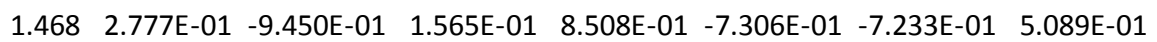
$5.397 \quad 2.796 \mathrm{E}-01 \quad-9.608 \mathrm{E}-01 \quad 1.505 \mathrm{E}-01 \quad 8.590 \mathrm{E}-01 \quad-7.427 \mathrm{E}-01 \quad-7.364 \mathrm{E}-01 \quad 5.183 \mathrm{E}-01$ 5.349 2.772E-01 $-9.426 \mathrm{E}-01 \quad 1.549 \mathrm{E}-01 \quad 8.500 \mathrm{E}-01 \quad-7.301 \mathrm{E}-01 \quad-7.220 \mathrm{E}-01 \quad 5.095 \mathrm{E}-01$

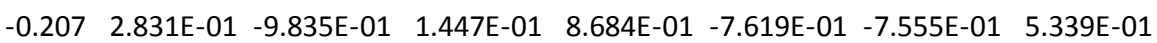

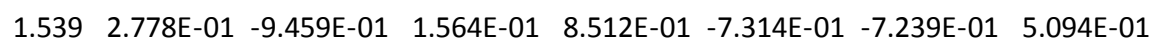

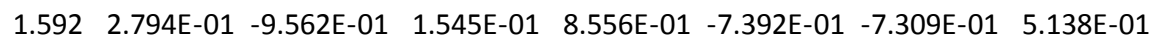

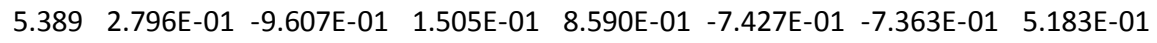
$2.304 \quad 3.393 \mathrm{E}-01-1.647 \mathrm{E}+00 \quad 1.825 \mathrm{E}-01 \quad 1.213 \mathrm{E}+00 \quad-1.288 \mathrm{E}+00 \quad-1.231 \mathrm{E}+00 \quad 8.720 \mathrm{E}-01$ $\begin{array}{llllllll}2.305 & 3.393 \mathrm{E}-01 & -1.647 \mathrm{E}+00 & 1.825 \mathrm{E}-01 & 1.213 \mathrm{E}+00 & -1.288 \mathrm{E}+00 & -1.231 \mathrm{E}+00 & 8.721 \mathrm{E}-01\end{array}$

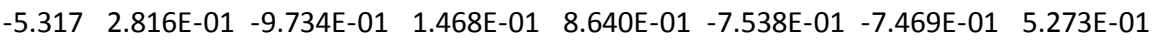

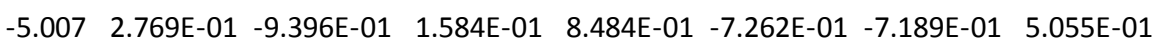

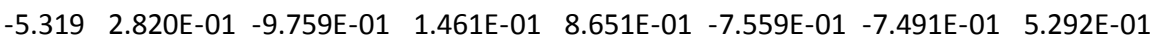
$0.567 \quad 2.786 \mathrm{E}-01 \quad-9.515 \mathrm{E}-01 \quad 1.550 \mathrm{E}-01 \quad 8.537 \mathrm{E}-01 \quad-7.351 \mathrm{E}-01 \quad-7.281 \mathrm{E}-01 \quad 5.116 \mathrm{E}-01$

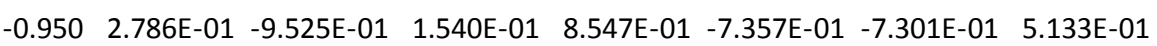

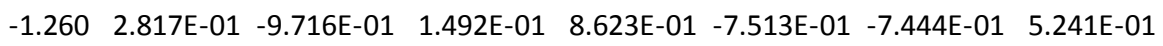
$\begin{array}{llllllll}-1.260 & 2.818 \mathrm{E}-01 & -9.722 \mathrm{E}-01 & 1.492 \mathrm{E}-01 & 8.625 \mathrm{E}-01 & -7.518 \mathrm{E}-01 & -7.447 \mathrm{E}-01 & 5.244 \mathrm{E}-01\end{array}$

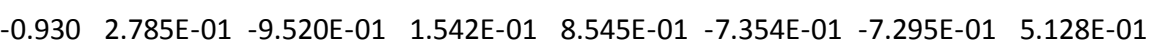
$0.572 \quad 2.788 \mathrm{E}-01 \quad-9.529 \mathrm{E}-01 \quad 1.543 \mathrm{E}-01 \quad 8.544 \mathrm{E}-01 \quad-7.363 \mathrm{E}-01 \quad-7.292 \mathrm{E}-01 \quad 5.127 \mathrm{E}-01$

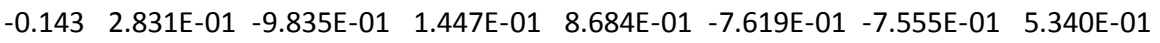

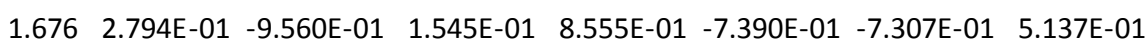
$\begin{array}{llllllll}1.602 & 2.778 \mathrm{E}-01 & -9.459 \mathrm{E}-01 & 1.564 \mathrm{E}-01 & 8.512 \mathrm{E}-01 & -7.314 \mathrm{E}-01 & -7.238 \mathrm{E}-01 & 5.093 \mathrm{E}-01\end{array}$ $5.405 \quad 2.781 \mathrm{E}-01 \quad-9.485 \mathrm{E}-01 \quad 1.530 \mathrm{E}-01 \quad 8.528 \mathrm{E}-01 \quad-7.347 \mathrm{E}-01 \quad-7.268 \mathrm{E}-01 \quad 5.131 \mathrm{E}-01$

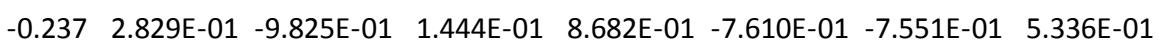
$\begin{array}{llllllll}1.508 & 2.776 \mathrm{E}-01 & -9.449 \mathrm{E}-01 & 1.565 \mathrm{E}-01 & 8.508 \mathrm{E}-01 & -7.305 \mathrm{E}-01 & -7.233 \mathrm{E}-01 & 5.089 \mathrm{E}-01\end{array}$

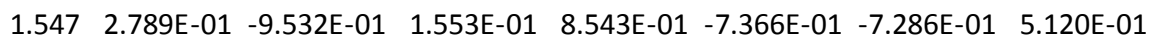
$\begin{array}{llllllll}5.368 & 2.772 \mathrm{E}-01 & -9.423 \mathrm{E}-01 & 1.550 \mathrm{E}-01 & 8.499 \mathrm{E}-01 & -7.299 \mathrm{E}-01 & -7.218 \mathrm{E}-01 & 5.093 \mathrm{E}-01\end{array}$

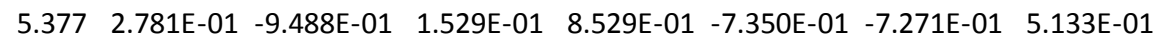

$-2.484$

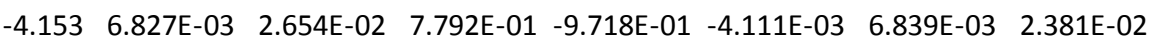

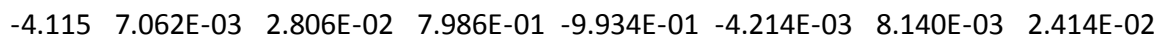
$\begin{array}{llllllll}0.016 & 4.110 \mathrm{E}-03 & 1.714 \mathrm{E}-02 & 7.890 \mathrm{E}-01 & -1.043 \mathrm{E}+00 & -7.956 \mathrm{E}-04 & 6.192 \mathrm{E}-03 & 1.175 \mathrm{E}-02\end{array}$

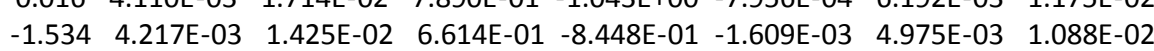
$\begin{array}{llllllll}0.093 & 4.114 \mathrm{E}-03 & 1.715 \mathrm{E}-02 & 7.886 \mathrm{E}-01 & -1.042 \mathrm{E}+00 & -8.201 \mathrm{E}-04 & 6.198 \mathrm{E}-03 & 1.177 \mathrm{E}-02\end{array}$ $\begin{array}{llllllll}-4.048 & 7.056 \mathrm{E}-03 & 2.801 \mathrm{E}-02 & 7.980 \mathrm{E}-01 & -9.926 \mathrm{E}-01 & -4.215 \mathrm{E}-03 & 8.097 \mathrm{E}-03 & 2.413 \mathrm{E}-02\end{array}$ $\begin{array}{llllllll}-4.092 & 6.824 \mathrm{E}-03 & 2.648 \mathrm{E}-02 & 7.780 \mathrm{E}-01 & -9.702 \mathrm{E}-01 & -4.115 \mathrm{E}-03 & 6.785 \mathrm{E}-03 & 2.381 \mathrm{E}-02\end{array}$ $\begin{array}{cccccccccc}3.501 & -1.451 & 4.204 \mathrm{E}-03 & 1.423 \mathrm{E}-02 & 6.622 \mathrm{E}-01 & -8.460 \mathrm{E}-01 & -1.590 \mathrm{E}-03 & 4.953 \mathrm{E}-03 & 1.086 \mathrm{E}-02 \\ -0.737 & -1.097 & 7.952 \mathrm{E}-03 & 3.314 \mathrm{E}-02 & 8.451 \mathrm{E}-01 & -1.042 \mathrm{E}+00 & -3.736 \mathrm{E}-03 & 1.054 \mathrm{E}-02 & 2.633 \mathrm{E}-02\end{array}$ $\begin{array}{lllllllll}1.464 & -0.992 & 8.118 \mathrm{E}-03 & 3.416 \mathrm{E}-02 & 8.533 \mathrm{E}-01 & -1.052 \mathrm{E}+00 & -3.785 \mathrm{E}-03 & 1.093 \mathrm{E}-02 & 2.701 \mathrm{E}-02\end{array}$ $\begin{array}{lllllllll}0.759 & -1.081 & 7.954 \mathrm{E}-03 & 3.314 \mathrm{E}-02 & 8.450 \mathrm{E}-01 & -1.041 \mathrm{E}+00 & -3.743 \mathrm{E}-03 & 1.055 \mathrm{E}-02 & 2.632 \mathrm{E}-02\end{array}$ $\begin{array}{lllllllll}-1.444 & -1.023 & 8.119 \mathrm{E}-03 & 3.415 \mathrm{E}-02 & 8.531 \mathrm{E}-01 & -1.052 \mathrm{E}+00 & -3.783 \mathrm{E}-03 & 1.091 \mathrm{E}-02 & 2.703 \mathrm{E}-02\end{array}$ 
AIM analysis of $\mathbf{2 c :}$

\begin{tabular}{|c|c|c|c|c|c|c|c|c|c|c|c|}
\hline \multicolumn{2}{|c|}{ Point } & $X$ & Z & Density & Laplacian & $G(r) / D(r)$ & $K(r) / D(r)$ & r) $E V(1)$ & $\mathrm{EV}(2)$ & \multicolumn{2}{|c|}{$E V(3)$} \\
\hline$c$ & 1 & & & & & & & & & & \\
\hline C & 2 & & & & & & & & & $3 E+05$ & +05 \\
\hline$N$ & 3 & & & & & & & & & & \\
\hline 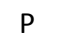 & 4 & & & & & & & & & & \\
\hline$N$ & 5 & & & & & & & & & +05 & +05 \\
\hline C & 6 & & & & & & & & & & \\
\hline C & 7 & & & & & & & & & +05 & \\
\hline C & 8 & & & & & & & & & & \\
\hline C & 9 & & & & & & & & & & \\
\hline$P$ & 10 & & & & & & & & & & $\mathrm{E}+07$ \\
\hline $\mathrm{N}$ & 11 & & & & & & & & & & \\
\hline C & 12 & & & & & & & & & & \\
\hline $\mathrm{C}$ & 13 & & & & & & & & & & +05 \\
\hline $\mathrm{C}$ & 14 & & & & & & & & & $E+05$ & $E+05$ \\
\hline $\mathrm{C}$ & 15 & & & & & & & & & & \\
\hline Se & 16 & & & & & & & & & & $E+0 S$ \\
\hline Se & 17 & & & & & & & & & $E+09$ & +0 \\
\hline $\mathrm{N}$ & 18 & & & & & & & & & & \\
\hline C & 19 & & & & & & & & & & \\
\hline C & & & & & & & & & & & \\
\hline C & 21 & & & & & & & & & & \\
\hline $\mathrm{C}$ & 22 & & & & & & & & & & +05 \\
\hline C & 23 & & & & & & & & & & \\
\hline$C$ & 24 & & & & & & & & & & \\
\hline $\mathrm{H}$ & 25 & & & & & & & & & & \\
\hline $\mathrm{H}$ & 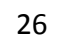 & & & & & & & & & & \\
\hline $\mathrm{H}$ & 7 & & & & & & & & & & \\
\hline $\mathrm{H}$ & & & & & & & & & & & \\
\hline$H$ & 29 & & & & & & & & & +00 & +00 \\
\hline $\mathrm{H}$ & 0 & & & & & & & & & & $=00$ \\
\hline $\mathrm{H}$ & & & & & & & & & & & \\
\hline $\mathrm{H}$ & & & & & & & & & & & \\
\hline $\mathrm{H}$ & & & & & & & & & & 0 & +00 \\
\hline $\mathrm{H}$ & & & & & & & & & & & \\
\hline $\mathrm{H}$ & & & & & & & & & 0 & & +00 \\
\hline$H$ & & & & & & & & & $-s$ & & \\
\hline $\mathrm{H}$ & & & & & & & & & & & \\
\hline $\mathrm{H}$ & 38 & & & & & & & & & & \\
\hline $\mathrm{H}$ & 39 & & & & & & & & . & 00 & +00 \\
\hline $\mathrm{H}$ & & & & & & & & & - & & \\
\hline $\mathrm{H}$ & 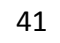 & & & & & & & & $-\varsigma$ & -9 & \\
\hline $\mathrm{H}$ & 42 & & & & & & & & & & \\
\hline $\mathrm{H}$ & 43 & & & & & & & & -00 & & \\
\hline $\mathrm{H}$ & 44 & & & & & & & & +00 & 0 & +00 \\
\hline $\mathrm{H}$ & & & & & & & & & -9 & 0 & \\
\hline $\mathrm{H}$ & 70 & & & & & & & & -9.2 & +00 & +00 \\
\hline $\mathrm{H}$ & 47 & & & & & & & & $-s$ & +00 & +00 \\
\hline $\mathrm{H}$ & 48 & & & & & & & & +00 & 0 & +00 \\
\hline $\mathrm{H}$ & 49 & & & & & -2 & & & $-9.202 E+00$ & -9 & +00 \\
\hline $\mathrm{H}$ & 50 & & & & & & & & $-9.185 E+00$ & $E+00$ & $=00$ \\
\hline $\mathrm{H}$ & 5 & & & & & & & & $-9.187 E+00$ & & \\
\hline $\mathrm{H}$ & 52 & & & & & & & & +00 & 0 & +00 \\
\hline $\mathrm{H}$ & 53 & & & & $4.470 \mathrm{E}-01$ & +01 & & & $-9.229 E+00$ & +00 & +00 \\
\hline 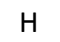 & & & & & & & & & & & \\
\hline $\mathrm{H}$ & 5 & & & & & & & & +00 & r00 & \\
\hline $\mathrm{H}$ & 56 & & & & & 01 & & & $-9.215 E+00$ & $E+00$ & $=00$ \\
\hline $\mathrm{H}$ & 57 & & & & -01 & -2 & & 1.5 & $-9.207 E+00$ & $-9.204 E+00$ & $E+00$ \\
\hline $\mathrm{H}$ & 58 & & & & 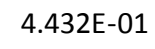 & -2 & & & $-9.137 E+00$ & $-9.135 \mathrm{E}+00$ & $-8.420 E+00$ \\
\hline $\mathrm{H}$ & 59 & & & 2.049 & $4.461 \mathrm{E}-01$ & $-2.696 E+01$ & $1.673 \mathrm{E}-02$ & 1.51 & $-9.215 E+00$ & $-9.213 E+00$ & $-8.535 E+00$ \\
\hline
\end{tabular}


$\begin{array}{llll}H & 60 & -7.114 & 3.922\end{array}$ $\begin{array}{llll}\mathrm{H} & 61 & -5.397 & 1.414\end{array}$ $\begin{array}{llll}H & 62 & -5.258 & -1.894\end{array}$

BCP 1

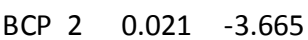

$\begin{array}{llll}\text { BCP } & 3 & -1.507 & -0.771\end{array}$ $\begin{array}{llll}\text { BCP } 4 & -1.509 & 0.992\end{array}$ $\begin{array}{lll}\text { BCP } 5 & -0.022 & 3.920\end{array}$ $\begin{array}{lll}\text { BCP } 6 & 1.163 & 5.567\end{array}$ $\begin{array}{lll}\text { BCP } 7 & -1.165 & -5.367\end{array}$ $\begin{array}{llll}\text { BCP } 8 & 1.235 & -5.348\end{array}$ $\begin{array}{lll}\text { BCP } 9 & 1.508 & -0.771\end{array}$ $\begin{array}{lll}\text { BCP } 10 & 1.507 & 0.992\end{array}$ $\begin{array}{lll}\text { BCP } 11 & 2.977 & -0.018\end{array}$ $\begin{array}{lll}\text { BCP } 12 & 5.416 & -0.194\end{array}$ $\begin{array}{lll}\text { BCP } 13 & 7.129 & 1.099\end{array}$ $\begin{array}{lll}\text { BCP } 14 & 7.232 & -1.320\end{array}$ $\begin{array}{lll}\text { BCP } 15 & 6.378 & -0.317\end{array}$ $\begin{array}{lll}\text { BCP } 16 & 3.686 & 0.274\end{array}$ $\begin{array}{lll}\text { BCP } 17 & -3.688 & 0.170\end{array}$ $\begin{array}{lll}\text { BCP } 18 & -2.978 & 0.092\end{array}$ $\begin{array}{lll}\text { BCP } 19 & -5.415 & -0.045\end{array}$ $\begin{array}{lll}\text { BCP } 20 & -7.232 & 1.094\end{array}$ $\begin{array}{lll}\text { BCP } 21 & -7.127 & -1.333\end{array}$ $\begin{array}{lll}\text { BCP } 22 & -6.376 & -0.178\end{array}$ $\begin{array}{lll}\text { BCP } 23 & -0.034 & 5.348\end{array}$ BCP $24 \quad-1.237 \quad 5.549$ $\begin{array}{lll}\text { BCP } 25 & -1.039 & -4.425\end{array}$ $\begin{array}{lll}\text { BCP } 26 & 0.047 & -6.262\end{array}$ $\begin{array}{lll}\text { BCP } 27 & 1.111 & -4.413\end{array}$ $\begin{array}{lll}\text { BCP } 28 & -2.341 & -5.873\end{array}$ $\begin{array}{lll}\text { BCP } 29 & -2.298 & -7.277\end{array}$ $\begin{array}{lll}\text { BCP } 30 & -3.416 & -5.470\end{array}$ $\begin{array}{lll}\text { BCP } 31 & 3.491 & -5.416\end{array}$ $\begin{array}{lll}\text { BCP } 32 & 2.400 & -7.241\end{array}$ $\begin{array}{llll}\text { BCP } 33 & 2.419 & -5.857\end{array}$ $\begin{array}{lll}\text { BCP } 34 & 8.029 & -2.335\end{array}$ $\begin{array}{lll}\text { BCP } 35 & 7.414 & -3.542\end{array}$ $\begin{array}{lll}\text { BCP } 36 & 9.195 & -2.385\end{array}$ $\begin{array}{lll}\text { BCP } 37 & 7.517 & -0.451\end{array}$ $\begin{array}{lll}\text { ВСР } 38 & 5.718 & -1.575\end{array}$ $\begin{array}{lll}\text { BCP } 39 & -7.829 & -2.489\end{array}$ $\begin{array}{lll}\text { BCP } 40 & -8.990 & -2.550\end{array}$ $\begin{array}{lll}\text { BCP } 41 & -7.120 & -3.565\end{array}$ $\begin{array}{lll}\text { BCP } 42 & -7.514 & -0.320\end{array}$ $\begin{array}{lll}\text { ВСР } 43 & 2.904 & -0.629\end{array}$ $\begin{array}{lll}\text { BCP } 44 & -2.904 & 0.326\end{array}$ $\begin{array}{lll}\text { BCP } 45 & -1.109 & 5.170\end{array}$ $\begin{array}{lll}\text { BCP } 46 & -0.048 & 6.976\end{array}$ $\begin{array}{lll}\text { BCP } 47 & 1.041 & 5.185\end{array}$ $\begin{array}{lll}\text { BCP } 48 & -2.422 & 5.798\end{array}$ $\begin{array}{lll}\text { BCP } 49 & -2.403 & 7.393\end{array}$ $\begin{array}{lll}\text { BCP } 50 & -3.493 & 5.608\end{array}$ $\begin{array}{lll}\text { BCP } 51 & 3.414 & 5.664\end{array}$ $\begin{array}{lll}\text { BCP } 52 & 2.296 & 7.426\end{array}$ $\begin{array}{lll}\text { BCP } 53 & 2.338 & 5.814\end{array}$ $\begin{array}{lll}\text { BCP } 54 & 7.833 & 2.494\end{array}$ $\begin{array}{lll}\text { BCP } 55 & 7.124 & 3.321\end{array}$ $\begin{array}{lll}\text { BCP } 56 & 8.993 & 2.303\end{array}$ $\begin{array}{lll}\text { BCP } 57 & 5.633 & 0.554\end{array}$ $\begin{array}{lll}\text { BCP } 58 & -8.033 & 2.354\end{array}$ $\begin{array}{lll}\text { BCP } 59 & -9.196 & 2.154\end{array}$
2.087 4.473E-01 -2.702E+01 1.670E-02 1.510E+01 -9.235E+00 -9.233E+00 -8.550E+00

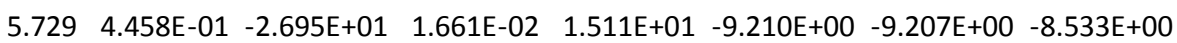

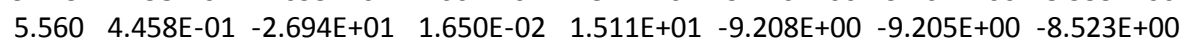

-3.846 2.493E-01 -6.279E-01 2.308E-01 6.296E-01 -4.940E-01 -4.801E-01 3.462E-01 -2.076 2.431E-01 -5.769E-01 4.783E-01 5.934E-01 -4.750E-01 -4.636E-01 3.617E-01 $\begin{array}{llllllll}-1.629 & 1.730 \mathrm{E}-01 & 2.221 \mathrm{E}-01 & 1.185 \mathrm{E}+00 & -3.209 \mathrm{E}-01 & -2.871 \mathrm{E}-01 & -2.554 \mathrm{E}-01 & 7.646 \mathrm{E}-01\end{array}$ $-1.507 \quad 1.752 \mathrm{E}-01 \quad 2.401 \mathrm{E}-01 \quad 1.207 \mathrm{E}+00 \quad-3.427 \mathrm{E}-01 \quad-2.939 \mathrm{E}-01 \quad-2.587 \mathrm{E}-01 \quad 7.927 \mathrm{E}-01$

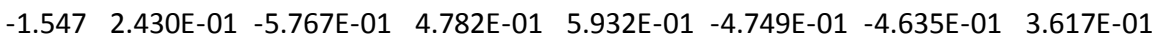

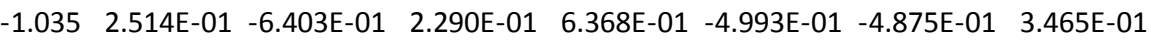
$\begin{array}{llllllll}-1.798 & 2.514 \mathrm{E}-01 & -6.403 \mathrm{E}-01 & 2.290 \mathrm{E}-01 & 6.368 \mathrm{E}-01 & -4.992 \mathrm{E}-01 & -4.875 \mathrm{E}-01 & 3.465 \mathrm{E}-01\end{array}$ $\begin{array}{llllllll}-1.799 & 2.510 \mathrm{E}-01 & -6.382 \mathrm{E}-01 & 2.288 \mathrm{E}-01 & 6.357 \mathrm{E}-01 & -4.980 \mathrm{E}-01 & -4.865 \mathrm{E}-01 & 3.463 \mathrm{E}-01\end{array}$ $\begin{array}{llllllll}-1.631 & 1.752 \mathrm{E}-01 & 2.406 \mathrm{E}-01 & 1.208 \mathrm{E}+00 & -3.433 \mathrm{E}-01 & -2.940 \mathrm{E}-01 & -2.588 \mathrm{E}-01 & 7.934 \mathrm{E}-01\end{array}$

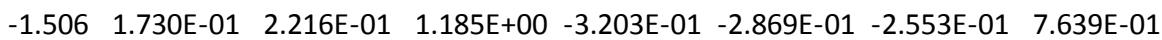

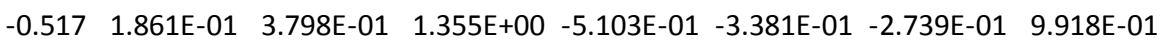

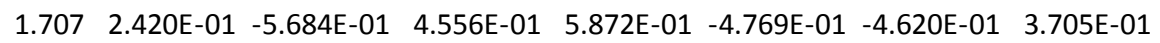
$1.743 \quad 2.508 \mathrm{E}-01 \quad-6.371 \mathrm{E}-01 \quad 2.292 \mathrm{E}-01 \quad 6.352 \mathrm{E}-01 \quad-4.988 \mathrm{E}-01 \quad-4.846 \mathrm{E}-01 \quad 3.463 \mathrm{E}-01$ $\begin{array}{llllllll}1.522 & 2.500 \mathrm{E}-01 & -6.327 \mathrm{E}-01 & 2.287 \mathrm{E}-01 & 6.326 \mathrm{E}-01 & -4.973 \mathrm{E}-01 & -4.826 \mathrm{E}-01 & 3.472 \mathrm{E}-01\end{array}$ $\begin{array}{llllllll}3.527 & 2.501 \mathrm{E}-01 & -6.338 \mathrm{E}-01 & 2.278 \mathrm{E}-01 & 6.335 \mathrm{E}-01 & -4.951 \mathrm{E}-01 & -4.850 \mathrm{E}-01 & 3.462 \mathrm{E}-01\end{array}$ -3.157 1.459E-01 -1.304E-01 4.307E-01 2.234E-01 -1.392E-01 -1.305E-01 1.394E-01

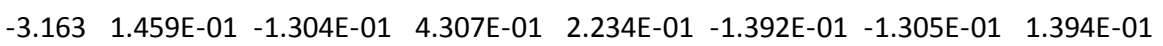
$\begin{array}{llllllll}-0.509 & 1.861 \mathrm{E}-01 & 3.798 \mathrm{E}-01 & 1.355 \mathrm{E}+00 & -5.103 \mathrm{E}-01 & -3.381 \mathrm{E}-01 & -2.739 \mathrm{E}-01 & 9.917 \mathrm{E}-01\end{array}$ $\begin{array}{llllllll}1.719 & 2.420 \mathrm{E}-01 & -5.685 \mathrm{E}-01 & 4.556 \mathrm{E}-01 & 5.873 \mathrm{E}-01 & -4.770 \mathrm{E}-01 & -4.620 \mathrm{E}-01 & 3.705 \mathrm{E}-01\end{array}$

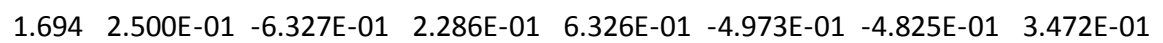
$\begin{array}{llllllll}1.575 & 2.508 \mathrm{E}-01 & -6.371 \mathrm{E}-01 & 2.292 \mathrm{E}-01 & 6.352 \mathrm{E}-01 & -4.988 \mathrm{E}-01 & -4.846 \mathrm{E}-01 & 3.463 \mathrm{E}-01\end{array}$ 3.540 2.501E-01 -6.339E-01 2.278E-01 6.336E-01 -4.951E-01 -4.850E-01 3.462E-01

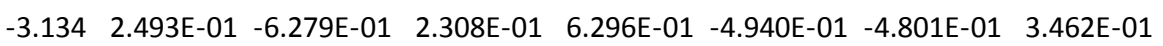
$\begin{array}{llllllll}-1.041 & 2.510 \mathrm{E}-01 & -6.382 \mathrm{E}-01 & 2.288 \mathrm{E}-01 & 6.357 \mathrm{E}-01 & -4.980 \mathrm{E}-01 & -4.865 \mathrm{E}-01 & 3.463 \mathrm{E}-01\end{array}$ -5.764 2.822E-01 -9.770E-01 1.459E-01 8.655E-01 -7.571E-01 -7.503E-01 5.304E-01

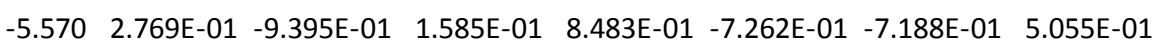

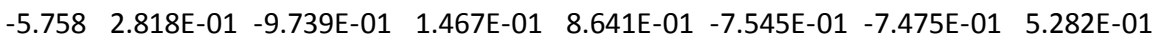
$0.046 \quad 2.788 \mathrm{E}-01 \quad-9.527 \mathrm{E}-01 \quad 1.545 \mathrm{E}-01 \quad 8.543 \mathrm{E}-01 \quad-7.362 \mathrm{E}-01 \quad-7.290 \mathrm{E}-01 \quad 5.124 \mathrm{E}-01$

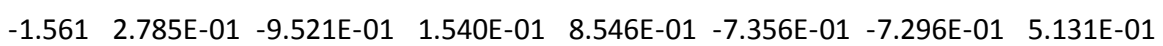

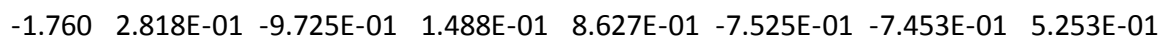

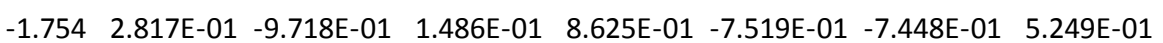

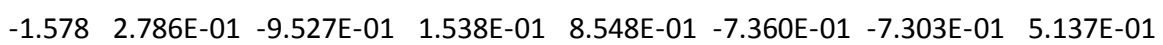
$0.043 \quad 2.786 \mathrm{E}-01 \quad-9.511 \mathrm{E}-01 \quad 1.554 \mathrm{E}-01 \quad 8.534 \mathrm{E}-01 \quad-7.347 \mathrm{E}-01 \quad-7.275 \mathrm{E}-01 \quad 5.111 \mathrm{E}-01$ $\begin{array}{llllllll}-0.326 & 2.829 E-01 & -9.827 E-01 & 1.441 E-01 & 8.683 E-01 & -7.616 E-01 & -7.557 E-01 & 5.347 E-01\end{array}$

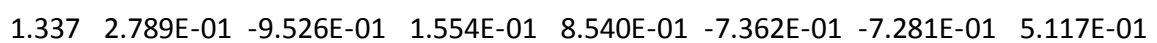
$\begin{array}{llllllll}1.471 & 2.777 \mathrm{E}-01 & -9.450 \mathrm{E}-01 & 1.565 \mathrm{E}-01 & 8.509 \mathrm{E}-01 & -7.307 \mathrm{E}-01 & -7.233 \mathrm{E}-01 & 5.091 \mathrm{E}-01\end{array}$ $5.473 \quad 2.796 \mathrm{E}-01 \quad-9.612 \mathrm{E}-01 \quad 1.503 \mathrm{E}-01 \quad 8.593 \mathrm{E}-01 \quad-7.430 \mathrm{E}-01 \quad-7.367 \mathrm{E}-01 \quad 5.186 \mathrm{E}-01$ $5.280 \quad 2.771 \mathrm{E}-01 \quad-9.414 \mathrm{E}-01 \quad 1.552 \mathrm{E}-01 \quad 8.494 \mathrm{E}-01 \quad-7.292 \mathrm{E}-01 \quad-7.211 \mathrm{E}-01 \quad 5.088 \mathrm{E}-01$ $\begin{array}{llllllll}-0.225 & 2.832 \mathrm{E}-01 & -9.839 \mathrm{E}-01 & 1.445 \mathrm{E}-01 & 8.685 \mathrm{E}-01 & -7.628 \mathrm{E}-01 & -7.563 \mathrm{E}-01 & 5.352 \mathrm{E}-01\end{array}$ $\begin{array}{llllllll}1.573 & 2.779 \mathrm{E}-01 & -9.463 \mathrm{E}-01 & 1.564 \mathrm{E}-01 & 8.514 \mathrm{E}-01 & -7.318 \mathrm{E}-01 & -7.241 \mathrm{E}-01 & 5.097 \mathrm{E}-01\end{array}$

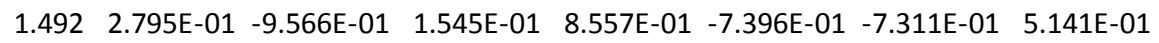

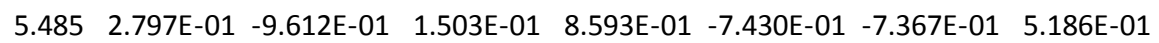
$2.177 \quad 3.387 \mathrm{E}-01-1.642 \mathrm{E}+00 \quad 1.826 \mathrm{E}-01 \quad 1.212 \mathrm{E}+00 \quad-1.285 \mathrm{E}+00 \quad-1.229 \mathrm{E}+00 \quad 8.716 \mathrm{E}-01$

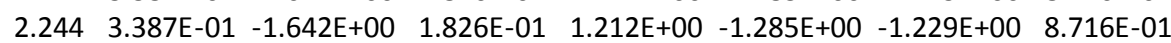
$\begin{array}{llllllll}-5.091 & 2.817 \mathrm{E}-01 & -9.737 \mathrm{E}-01 & 1.467 \mathrm{E}-01 & 8.641 \mathrm{E}-01 & -7.545 \mathrm{E}-01 & -7.475 \mathrm{E}-01 & 5.282 \mathrm{E}-01\end{array}$

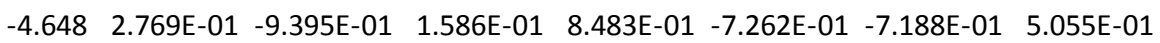

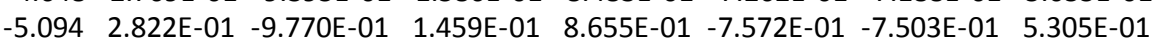
$0.853 \quad 2.786 \mathrm{E}-01 \quad-9.511 \mathrm{E}-01 \quad 1.554 \mathrm{E}-01 \quad 8.535 \mathrm{E}-01 \quad-7.347 \mathrm{E}-01 \quad-7.276 \mathrm{E}-01 \quad 5.111 \mathrm{E}-01$

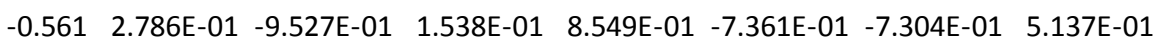

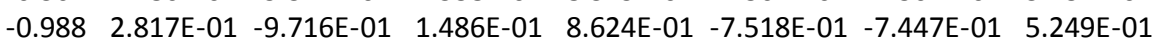

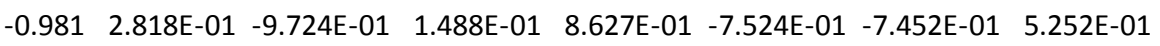

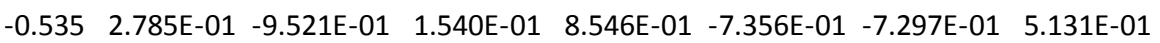

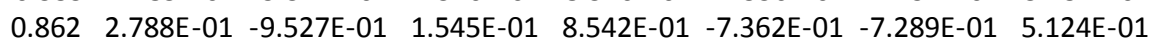
$0.121 \quad 2.832 \mathrm{E}-01 \quad-9.838 \mathrm{E}-01 \quad 1.445 \mathrm{E}-01 \quad 8.685 \mathrm{E}-01 \quad-7.628 \mathrm{E}-01 \quad-7.563 \mathrm{E}-01 \quad 5.352 \mathrm{E}-01$ $1.970 \quad 2.795 \mathrm{E}-01 \quad-9.566 \mathrm{E}-01 \quad 1.544 \mathrm{E}-01 \quad 8.557 \mathrm{E}-01 \quad-7.396 \mathrm{E}-01 \quad-7.311 \mathrm{E}-01 \quad 5.141 \mathrm{E}-01$

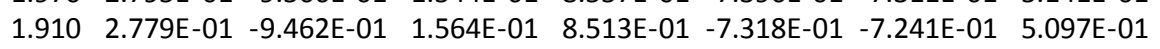

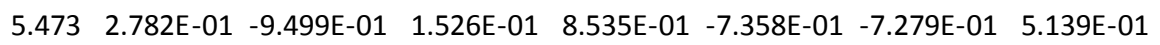

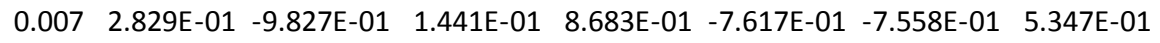

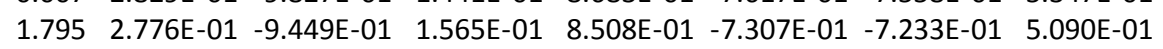




$\begin{array}{lcccccccccc}\text { BCP } 60 & -7.416 & 3.320 & 1.820 & 2.789 E-01 & -9.527 E-01 & 1.554 E-01 & 8.540 E-01 & -7.362 E-01 & -7.281 E-01 & 5.117 E-01 \\ \text { BCP } 61 & -5.718 & 0.823 & 5.451 & 2.771 E-01 & -9.416 E-01 & 1.552 E-01 & 8.495 E-01 & -7.292 E-01 & -7.211 E-01 & 5.088 E-01 \\ \text { BCP 62 } & -5.627 & -1.311 & 5.344 & 2.783 E-01 & -9.500 E-01 & 1.526 E-01 & 8.535 E-01 & -7.359 E-01 & -7.280 E-01 & 5.139 E-01 \\ \text { RCP 1 } & -1.982 & -2.433 & -4.340 & 6.916 E-03 & 2.673 E-02 & 7.828 E-01 & -9.662 E-01 & -3.947 E-03 & 8.354 E-03 & 2.232 E-02 \\ \text { RCP 2 } & 2.061 & -2.381 & -4.380 & 6.715 E-03 & 2.521 E-02 & 7.590 E-01 & -9.386 E-01 & -3.900 E-03 & 6.865 E-03 & 2.225 E-02 \\ \text { RCP 3 } & -5.388 & -3.141 & -1.715 & 4.237 E-03 & 1.403 E-02 & 6.507 E-01 & -8.277 E-01 & -1.703 E-03 & 4.497 E-03 & 1.123 E-02 \\ \text { RCP 4 } & 4.808 & -3.383 & -0.109 & 4.119 E-03 & 1.712 E-02 & 7.861 E-01 & -1.039 E+00 & -8.396 E-04 & 6.141 E-03 & 1.182 E-02 \\ \text { RCP 5 } & -2.059 & 2.967 & -4.007 & 6.724 E-03 & 2.520 E-02 & 7.581 E-01 & -9.368 E-01 & -3.907 E-03 & 6.866 E-03 & 2.224 E-02 \\ \text { RCP 6 } & 1.980 & 3.014 & -3.958 & 6.914 E-03 & 2.680 E-02 & 7.847 E-01 & -9.691 E-01 & -3.947 E-03 & 8.410 E-03 & 2.234 E-02 \\ \text { RCP 7 } & -4.809 & 3.370 & 0.367 & 4.104 E-03 & 1.707 E-02 & 7.861 E-01 & -1.040 E+00 & -8.358 E-04 & 6.107 E-03 & 1.180 E-02 \\ \text { RCP 8 } & 5.388 & 3.350 & -1.258 & 4.224 E-03 & 1.400 E-02 & 6.512 E-01 & -8.287 E-01 & -1.686 E-03 & 4.466 E-03 & 1.122 E-02 \\ \text { RCP 9 } & 5.944 & -1.018 & -1.180 & 7.597 E-03 & 3.046 E-02 & 8.187 E-01 & -1.002 E+00 & -3.444 E-03 & 1.028 E-02 & 2.362 E-02 \\ \text { RCP 10 } & 5.812 & 1.216 & -0.916 & 7.836 E-03 & 3.169 E-02 & 8.264 E-01 & -1.011 E+00 & -3.534 E-03 & 1.050 E-02 & 2.473 E-02 \\ \text { RCP 11 } & -5.949 & 1.169 & -1.027 & 7.588 E-03 & 3.039 E-02 & 8.179 E-01 & -1.001 E+00 & -3.443 E-03 & 1.024 E-02 & 2.359 E-02 \\ \text { RCP 12 } & -5.811 & -1.077 & -1.073 & 7.828 E-03 & 3.175 E-02 & 8.281 E-01 & -1.014 E+00 & -3.522 E-03 & 1.052 E-02 & 2.475 E-02\end{array}$

